Lek.med. Marek Kanikowski

\title{
Wartości dawek w gruczole krokowym i narządach krytycznych w odmiennych schematach brachyterapii HDR.
}

\author{
Rozprawa doktorska \\ wykonana w Zakładzie Brachyterapii \\ Wielkopolskiego Centrum Onkologii w Poznaniu \\ Promotor: dr hab. n. med. Janusz Skowronek
}

Poznań 2010 


\section{Spis treści}

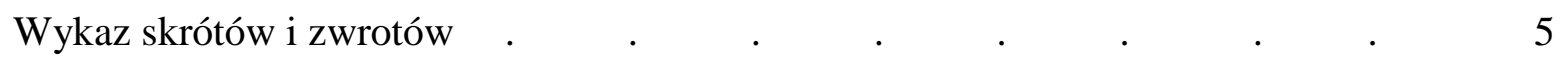

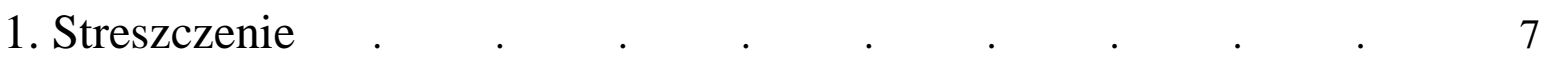

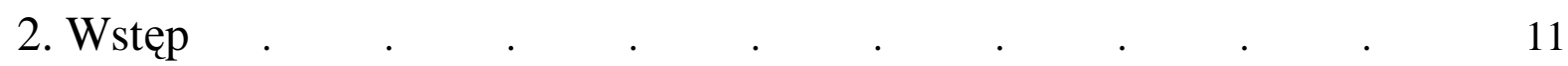

2.1. Rak gruczołu krokowego - epidemiologia, objawy, diagnostyka,

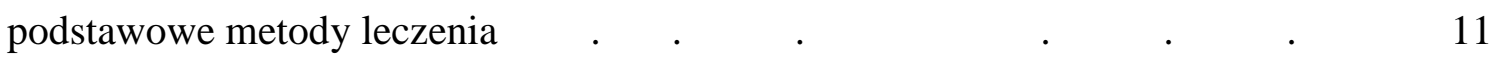

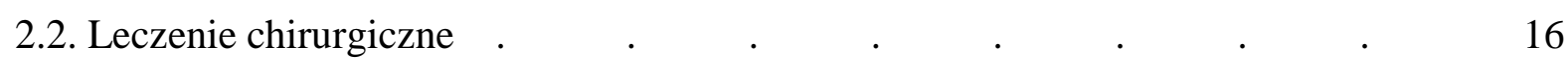

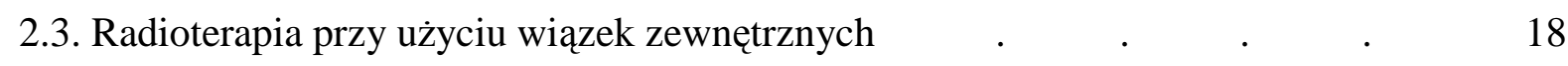

2.4. Brachyterapia HDR raka gruczołu krokowego - rys historyczny • 20

2.5. Brachyterapia HDR raka gruczołu krokowego - opis metody 21

2.6. Brachyterapia HDR raka gruczołu krokowego - schematy frakcjonowania dawki,

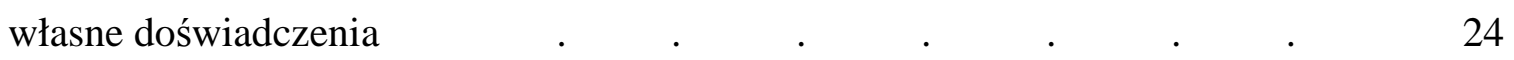

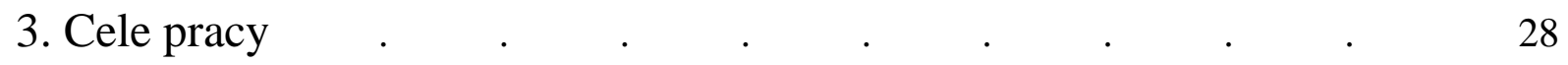

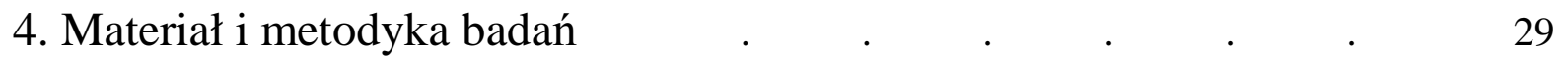

4.1. Kwalifikacja do badania i kryteria wyłączenia . $\quad . \quad$. $\quad$. $\quad$. $\quad 29$

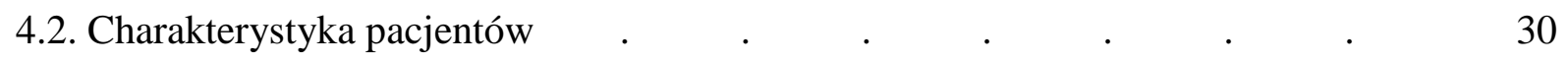

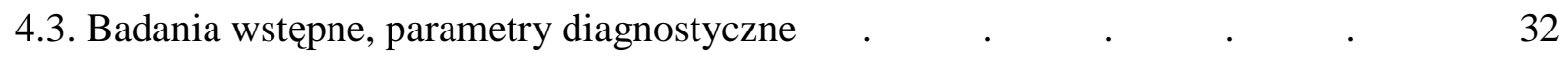

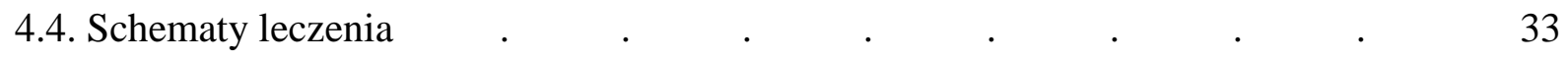

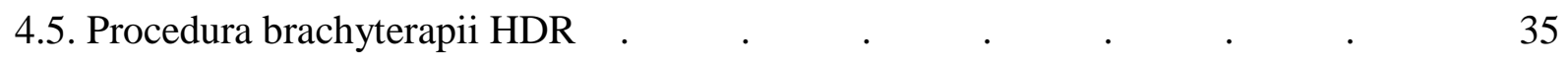

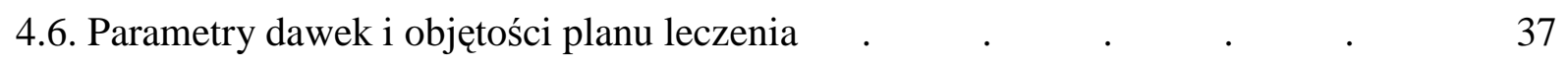

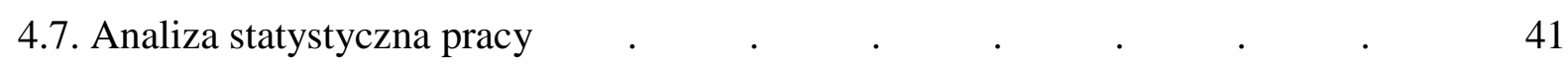

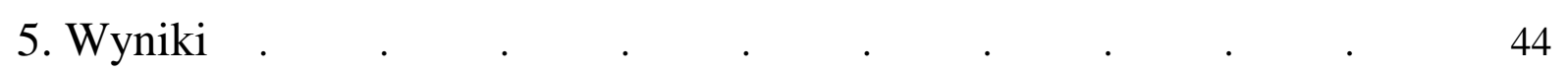

5.1. Wartości dawek i objętości w gruczole krokowym i narządach krytycznych . $\quad 44$

5.2. Porównanie zmienności wartości dawek i objętości w obrębie grup pacjentów. 49

5.2.1. Zmienność wartości dawek i objętości w grupie II. ․ . . . . . $\quad 51$

5.2.2. Zmienność wartości dawek i objętości w grupie III. 54

5.3. Porównanie zmienności średnich wartości dawek i objętości między

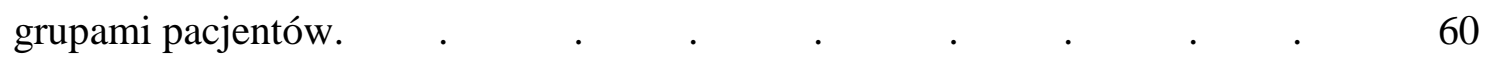

5.4. Analiza zależności pomiędzy czynnikami prognostycznymi a wartościami dawek

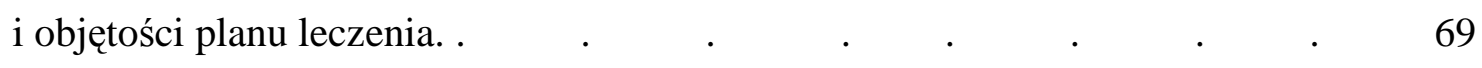

5.4.1. Zależności parametrów prognostycznych i wartości dawek oraz objętości w grupie I. 73 5.4.2. Zależności parametrów prognostycznych i wartości dawek oraz objętości w grupie II 73 
5.4.3. Zależności parametrów prognostycznych i wartości dawek oraz objętości w grupie III

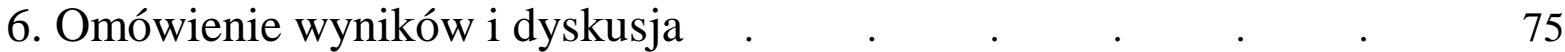

7. Wnioski . . . . . . . . . . . . . . . 85

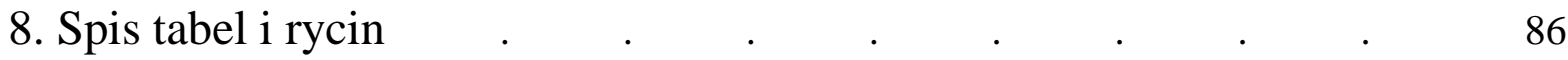

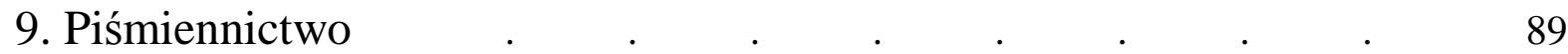


Wykaz skrótów i zwrotów zawartych w pracy.

\begin{tabular}{|c|c|}
\hline AJCC/UICC & $\begin{array}{l}\text { American Joint Cancer Committee/Union Internationale Contre le } \\
\text { Cancer }\end{array}$ \\
\hline AUA & $\begin{array}{l}\text { Skala objawów wg. Amerykańskiego Towarzystwa Urologicznego } \\
\text { (ang. American Urological Association symptom scale) }\end{array}$ \\
\hline BC & Biochemiczna kontrola miejscowa (ang. biochemical control) \\
\hline BED & Biologiczna dawka efektywna (ang. biological effective dose) \\
\hline bNED & $\begin{array}{l}\text { Biochemicznie bez cech wznowy (ang. biochemical no evidence of } \\
\text { desease) }\end{array}$ \\
\hline BPH & $\begin{array}{l}\text { Łagodny rozrost gruczołu krokowego (ang. benign prostatic } \\
\text { hyperplasia) }\end{array}$ \\
\hline CET & California Endocurietherapy Cancer Center \\
\hline DRE & Badanie per rectum (ang. digital rectal examination) \\
\hline DVC & Ograniczenia wartości dawek (ang. dose volume constraints) \\
\hline EBRT & Teleradioterapia (ang. external beam radiation therapy) \\
\hline EQD2 & $\begin{array}{l}\text { Dawki ekwiwalentne odpowiadające podanej dawce } \mathrm{z} \text { teleradioterapii } \\
\text { frakcjonowanej po } 2 \mathrm{~Gy} \text { (ang. equivalent dose in } 2 \mathrm{~Gy} \text { ) }\end{array}$ \\
\hline GEC/ESTRO/EAU & $\begin{array}{l}\text { Groupe European de Curietherapie/European Society for Therapeutic } \\
\text { Radiology and Oncology/ European Association of Urology }\end{array}$ \\
\hline GS & Stopień złośliwości histologicznej wg Gleasona (ang. Gleason score) \\
\hline HDR & Wysoka moc dawki (ang. high-dose-rate) \\
\hline HDR-BRT & $\begin{array}{l}\text { Brachyterapia z użyciem źródeł o wysokiej mocy dawki (ang. high- } \\
\text { dose-rate brachytherapy) }\end{array}$ \\
\hline HIFU & $\begin{array}{l}\text { Leczenie ultradźwiękami o wysokiej częstotliwości (ang. high intensity } \\
\text { focused ultrasound) }\end{array}$ \\
\hline HRPC & $\begin{array}{l}\text { Rak gruczołu krokowego hormonooporny (ang. hormone resistant } \\
\text { prostate carcinoma) }\end{array}$ \\
\hline IGRT & Radioterapia kierowana obrazem (ang. image guided radiation therapy) \\
\hline ILA & Śródtkankowa ablacja laserowa (ang. interstitial laser ablation) \\
\hline IMRT & $\begin{array}{l}\text { Radioterapia z modulacją intensywności dawki promieniowania (ang. } \\
\text { intensity modulated radiation therapy) }\end{array}$ \\
\hline IPSS & $\begin{array}{l}\text { Międzynarodowa skala powikłań układu moczowego (ang. international } \\
\text { prostate symptoms score) }\end{array}$ \\
\hline $\mathbf{L Q}$ & Model liniowo-kwadratowy (ang. linear-quadrant model) \\
\hline
\end{tabular}




\begin{tabular}{|c|c|}
\hline OAR & $\begin{array}{l}\text { Narządy i struktury zdrowe, tzw. krytyczne, znajdujące się w pobliżu } \\
\text { obszaru napromienianego (ang. Organs at Risk) }\end{array}$ \\
\hline PCa & Rak gruczołu krokowego (ang. prostate cancer) \\
\hline PSA & Swoisty antygen sterczowy (ang. prostate specific antygen) \\
\hline PSAD & Gęstość swoistego antygenu sterczowego \\
\hline PSAV & Szybkość wzrostu stężenia swoistego antygenu sterczowego. \\
\hline RTOG/EORTC & $\begin{array}{l}\text { Radiation Therapy Oncology Group/European Organization for Research } \\
\text { and Treatment of Cancer }\end{array}$ \\
\hline TCP & Prawdopodobieństwo kontroli miejscowej (ang. tumor control probability) \\
\hline Test K-W & Test Kruskala-Wallisa \\
\hline TNM & Klasyfikacja zaawansowania klinicznego nowotworów. \\
\hline TRUS & Przezodbytnicza ultrasonografia (ang. transrectal ultrasound) \\
\hline TUR-P & $\begin{array}{l}\text { Przezcewkowa resekcja gruczołu krokowego (ang. transurethral resection } \\
\text { of prostate) }\end{array}$ \\
\hline LDR & Niska moc dawki (ang. low-dose-rate) \\
\hline WBH & William Beaumont Hospital \\
\hline 3D - CRT & $\begin{array}{l}\text { Trójwymiarowa, konformalna radioterapia (ang. 3-dimentional conformal } \\
\text { radiotherapy) }\end{array}$ \\
\hline$\alpha / \beta$ & Radiobiologiczny współczynnik określający zdolność naprawczą komórek \\
\hline
\end{tabular}




\section{Streszczenie}

Cel pracy: 1. Porównanie wybranych wartości dawek i parametrów objętości leczonych techniką HDR-BRT w trzech schematach frakcjonowania, z uwzględnieniem dawek biologicznych.

2. Ocena wpływu wybranych czynników prognostycznych na uzyskane wartości dawek i parametrów objętości, w zależności od różnych schematów brachyterapii HDR.

Materiał i metody: W okresie od czerwca 2006 do października 2007, w Zakładzie Brachyterapii Wielkopolskiego Centrum Onkologii w Poznaniu badaniem objęto 65 chorych mężczyzn z rozpoznaniem raka gruczołu krokowego. 55 pacjentów leczono metodą skojarzoną: HDR-BRT + teleradioterapia (EBRT), 37 otrzymało jedną, a 18 dwie frakcje brachyterapii śródtkankowej według schematu odpowiednio: EBRT $50 \mathrm{~Gy} /+$ HDR-BRT 15 Gy (grupa I) i EBRT 46 Gy/+ HDR - BRT 2 x 10 Gy (grupa II). U 10 chorych zastosowano monoterapię HDR - BRT jako metodę samodzielną, w trzech frakcjach i dawce całkowitej 45 Gy (grupa III). Analizie poddano wartości dawek i objętości dla gruczołu krokowego: $\mathrm{D}_{\min -\mathrm{p}}, \mathrm{D}_{\text {max-p }}, \mathrm{D}_{\text {mean-p }}, \mathrm{D}_{90-\mathrm{p}}, \mathrm{SD}_{\mathrm{p}}, \mathrm{V}_{100-\mathrm{p}}$, $\mathrm{V}_{120-\mathrm{p}}, \mathrm{V}_{150-\mathrm{p}} \mathrm{i} \mathrm{V}_{200-\mathrm{p}}$ oraz $\mathrm{D}_{\text {min-u, }}, \mathrm{D}_{\text {max-u, },}, \mathrm{D}_{\text {mean-u,r }}, \mathrm{D}_{10-\mathrm{u}, \mathrm{r}}, \mathrm{SD}_{-\mathrm{u}, \mathrm{r}}, \mathrm{V}_{\text {crit-u, }} \mathrm{i} \mathrm{V}_{100-\mathrm{u}, \mathrm{r}}$ odpowiednio dla cewki moczowej i odbytnicy. Wartości dawek i objętości porównano celem oceny ich zmienności w różnych schematach leczenia. Dokonano ponadto oceny wpływu: wieku, stopnia zaawansowania klinicznego (system TNM), stopnia złośliwości histologicznej według Gleasona (GS), wyjściowej wartości PSA (i-PSA), liczby implantowanych igieł śródtkankowych oraz objętości gruczołu krokowego na wartości dawek i objętości planu leczenia.

Wyniki: Najwyższą wartość dawki $\mathrm{D}_{90-\mathrm{p}}$ w obrębie gruczołu krokowego zaobserwowano w grupie III (mediana 94,31\%, BED $90-\mathrm{p}=155,31 \mathrm{~Gy}$ ) oraz grupie I $(92,05 \%, 151,08 \mathrm{~Gy})$. Biologiczna dawka średnia $\left(\mathrm{BED}_{\text {mean-p}}\right)$ dla wszystkich grup chorych była równa 209,09 Gy. Wartość dawki podanej na 10\% objętości cewki moczowej jako narządu krytycznego $\left(\mathrm{BED}_{10-\mathrm{u}}\right)$ wynosiła średnio od 53,47 Gy w grupie II do 109,88 Gy w I, na jedną frakcję. Wartość $\mathrm{BED}_{10-\mathrm{r}}$ dla odbytnicy, dla wszystkich chorych wyniosła średnio 46,92 Gy, Najmniejszą dawką BED $_{\text {mean-r }}$ stwierdzono w grupie III (20,11 Gy), wyższą w grupach I i III, odpowiednio 39,62 i 42,97 Gy. Porównanie wartości dawek i objętości pomiędzy frakcjami brachyterapii HDR wykazało nieznaczne zmiany, w przeważającej części nieistotne statystycznie (testy Wilcoxona i Friedmana). W grupie II zauważono tendencję do zmniejszenia dawek w drugiej frakcji w obrębie odbytnicy (spadek $\mathrm{D}_{\text {max-r }}, \mathrm{V}_{100-\mathrm{r}}$ ) kosztem zmniejszenia $\mathrm{D}_{90-\mathrm{p}}$, $\mathrm{BED}_{90-\mathrm{p}}$ dla gruczołu krokowego oraz $\mathrm{D}_{\text {max-u }}, \mathrm{BED}_{\text {max-u }}, \mathrm{V}_{100-\mathrm{u}}, \mathrm{D}_{\text {mean-u}}, \mathrm{BED}_{\text {mean-u }}$ dla cewki moczowej. W grupie III w trzeciej frakcji, w obrębie obszaru napromienianego zaobserwowano tendencję do zmniejszenia objętości punktów dawek wysokich $\left(\mathrm{V}_{200-\mathrm{p}}, \mathrm{V}_{150-\mathrm{p}}, \mathrm{V}_{120-\mathrm{p}}, \mathrm{D}_{\text {max-p }}\right)$, kosztem parametrów $\mathrm{D}_{90-\mathrm{p}}, \mathrm{BED}_{90-\mathrm{p}}, \mathrm{V}_{100-\mathrm{p}}$ dla gruczołu krokowego, zmniejszenia $\mathrm{D}_{10-\mathrm{u}}, \mathrm{BED}_{10-\mathrm{u}}, \mathrm{V}_{100-\mathrm{u}}$ oraz wzrostu $\mathrm{V}_{100-\mathrm{r}}, \mathrm{D}_{\text {max-r }}$, $\mathrm{BED}_{\text {max-r }}$ dla odbytnicy. Istotne różnice wykazano po porównaniu dawek we wszystkich trzech schematach leczenia. Wartości dawek i objętości w grupie II okazały się statystycznie różne od pozostałych ( $\left.\mathrm{SD}_{-\mathrm{p}}, \mathrm{V}_{120-\mathrm{p}}, \mathrm{D}_{\text {max-p }}, \mathrm{D}_{\text {mean-u }}, \mathrm{D}_{\text {min-u }}, \mathrm{SD}_{-\mathrm{u}}\right)$. Wykazano istotny wpływ czynników wieku, objętości, liczby aplikatorów na wysokość dawek w gruczole krokowym, cewki moczowej, odbytnicy. Parametr wieku korelował wprost proporcjonalnie z $\mathrm{D}_{\max -\mathrm{p}} \mathrm{i} \mathrm{BED}_{\max \mathrm{p}}$ (II grupa) oraz odwrotnie proporcjonalnie $\mathrm{V}_{100-\mathrm{p}}$ (II grupa), $\mathrm{V}_{150-\mathrm{p}}, \mathrm{V}_{120-\mathrm{p}}, \mathrm{D}_{\text {min-r }}, \mathrm{BED}_{\text {min-r }}$ (III grupa). Objętość gruczołu okazała się wprost proporcjonalna do $\mathrm{D}_{90-\mathrm{p}}, \mathrm{V}_{100-\mathrm{p}}$ we wszystkich grupach, wprost proporcjonalna do $\mathrm{D}_{10-\mathrm{r}}$, $\mathrm{BED}_{10-\mathrm{r}}, \mathrm{D}_{\text {mean-r-r}}, \mathrm{BED}_{\text {mean-r }} \mathrm{w}$ II grupie, wprost proporcjonalna do $\mathrm{D}_{\text {max-u}}, \mathrm{BED}_{\text {max-u }}$ w II grupie wprost proporcjonalna do $\mathrm{V}_{100-u}, \mathrm{D}_{\text {mean-u}}$, $\mathrm{BED}_{\text {mean-u }} \mathrm{w}$ I grupie. Większa liczba aplikatorów igłowych w I grupie była 
związana z wyższą wartością parametrów $\mathrm{D}_{90-\mathrm{p}}, \mathrm{BED}_{90-\mathrm{p}}, \mathrm{V}_{100-\mathrm{p}}$ (I grupa), mniejszą wartością $\mathrm{V}_{200-\mathrm{p}}, \mathrm{V}_{100-\mathrm{r}}(\mathrm{I}$ grupa), mniejszą wartością $\mathrm{D}_{\max -\mathrm{u}}$ i $\mathrm{BED}_{\max -\mathrm{u}}$ (II grupa) oraz większą wartością $\mathrm{V}_{150-\mathrm{p}}, \mathrm{V}_{120-\mathrm{p}}, \mathrm{V}_{100-\mathrm{p}}$ (III grupa).

Wnioski: 1. Wysokość dawki w obszarze referencyjnym (gruczoł krokowy) ulegała obniżeniu po korekcie dawki w odbytnicy, podobną zależność zaobserwowano dla wartości dawek w cewce moczowej. Wzrost dawki frakcyjnej zwiększa ryzyko nieoczekiwanych wartości dawek i objętości w obszarze napromienianym i narządach krytycznych.

2.Oznacza to, że dążenie do obniżenia dawek celem oszczędzenia narządów zdrowych może wiązać się z mniej korzystnym rozkładem dawki w obrębie narządu leczonego - gruczołu krokowego.

3. W grupie III wzrost wieku był powiązany z korzystniejszym rozkładem dawek. W grupie II niższy wiek był związany $\mathrm{z}$ obniżeniem dawki w obszarze referencyjnym oraz wzrostem $\mathrm{w}$ narządach krytycznych. Wzrost objętości gruczołu krokowego we wszystkich grupach korelował z lepszym rozkładem dawki. Wiązała się z tym większa liczba zastosowanych aplikatorów w grupie I i II, jedynie w grupie III wraz ze wzrostem liczby aplikatorów wzrastało niebezpieczeństwo wzrostu dawek w obrębie gruczołu krokowego.

4. Stwierdzono zależność analizowanych wyników prognostycznych: wieku, objętości gruczołu i liczby aplikatorów z wartościami dawek w obszarze referencyjnym oraz narządach krytycznych.

Powyższe obserwacje sugerują ryzyko uzyskania gorszego rozkładu dawki HDR-BRT w grupie młodych mężczyzn o niewielkiej objętości gruczołu krokowego. 


\section{Abstract}

Aim: 1. Comparing dose and volume parameters in three schemes of HDR-BRT modality treatment including biological doses.

2. Estimation of relations between particular prognostic factors and values of dose-volume parameters in different HDR-BRT fractionation schemes.

Material and methods: 65 prostate cancer patients with localized prostate cancer were treated between June 2006 and October 2007 by HDR brachytherapy. 55 of cases HDR-BRT was administered as a boost after external beam radiotherapy (EBRT). 37 of patients underwent one sesion of brachyterapy ( 1 x 15 Gy - group I) and 18 two fractions of interstitial treatment $(2 \times 10$ Gy - group II) after EBRT doses 50 and 46 Gy respectively. The number of 10 men were treated by HDR-BRT as a sole modality treatment (total dose $45 \mathrm{~Gy}$ in three fractions - group III). Dose and volume parameters of target and organs at risk were analyzed: $\mathrm{D}_{\text {min-p }}$, $\mathrm{D}_{\text {max-p }}, \mathrm{D}_{\text {mean-p }}, \mathrm{D}_{90-\mathrm{p},}, \mathrm{SD}_{-\mathrm{p}}, \mathrm{V}_{100-\mathrm{p}}, \mathrm{V}_{120-\mathrm{p}}, \mathrm{V}_{150-\mathrm{p}} \mathrm{i} \mathrm{V}_{200-\mathrm{p}}$ oraz $\mathrm{D}_{\text {min-u,r, }}, \mathrm{D}_{\text {max-u, },}, \mathrm{D}_{\text {mean-u,r, }}, \mathrm{D}_{10-\mathrm{u}, \mathrm{r}}, \mathrm{SD}_{-\mathrm{u}, \mathrm{r}}, \mathrm{V}_{\text {crit-u,r, }} \mathrm{i} \mathrm{V}_{100-\mathrm{u}, \mathrm{r}}$, for prostate gland, urethra and rectum respectively. The comparison of dose-volume parameters has been done to reveal it's variation in different schemes groups. There also has been effort to estimate influence of such a prognostic factors as: age, TNM clinical score, Gleason pathologic score, initial PSA value, number of interstitial needles used and prostate gland volume on dose-volume HDR-BRT parameters.

Results: I observed the largest dose $\mathrm{D}_{90-\mathrm{p}}$ for prostate gland in group III (medial value $94,31 \%$, $\mathrm{BED}_{90 \text { - }}$ $\mathrm{p}=155,31 \mathrm{~Gy})$ and group I $(92,05 \%, 151,08 \mathrm{~Gy})$. Biological effective dose $\left(\mathrm{BED}_{\text {mean-p }}\right)$ for all patients was estimated on $209,09 \mathrm{~Gy}$. The value of biological dose given to $10 \%$ of urethra volume $\left(\mathrm{BED}_{10-\mathrm{u}}\right)$ was found as 53,47 Gy in group II and 109,88 Gy in I. BED 10-r $_{\text {r }}$ for rectum, for all patients enrolled to study, was 46,92 Gy in medial value. Least dose $\mathrm{BED}_{\text {mean-r }}$ was observed in group III (20,11 Gy), in I and III doses were higher, respectively 39,62 and 42,97 Gy. Comparison of dose-volume parameters between HDR-BRT fractions revealed slight changes, in most cases statistically insignificant (Wilcoxon, Friedmann tests). There is a tendency of reduction of rectum doses in group II $\left(\mathrm{D}_{\text {max-r }}, \mathrm{V}_{100-\mathrm{r}}\right)$ concurrent with $\mathrm{D}_{90-\mathrm{p}}, \mathrm{BED}_{90-\mathrm{p}}$ reduction for target and reduction of $\mathrm{D}_{\text {max-u }}, \mathrm{BED}_{\text {max-u }}, \mathrm{V}_{100-\mathrm{u}}, \mathrm{D}_{\text {mean-u}}, \mathrm{BED}_{\text {mean-u }}$ for urethra. In the third fraction in III group of HDRBRT monotherapy I observed the tendency of lowering high doses points in prostate volume $\left(\mathrm{V}_{200-\mathrm{p}}, \mathrm{V}_{150-\mathrm{p}}\right.$, $\mathrm{V}_{120-\mathrm{p}}, \mathrm{D}_{\text {max-p }}$ ) concurrently with $\mathrm{D}_{90-\mathrm{p}}, \mathrm{BED}_{90-\mathrm{p}}, \mathrm{V}_{100-\mathrm{p}}$ target parameters, $\mathrm{D}_{10-\mathrm{u}}, \mathrm{BED}_{10-\mathrm{u}}, \mathrm{V}_{100-\mathrm{u}}$ urethra parameters which caused increase of $\mathrm{V}_{100-\mathrm{r}}, \mathrm{D}_{\text {max-r }}, \mathrm{BED}_{\text {max-r }}$ rectum ones. There has been statistically significant difference in comparison all schemes of HDR-BRT treatment. II group dose-volume parameters were different from the others ( $\left.\mathrm{SD}_{-\mathrm{p}}, \mathrm{V}_{120-\mathrm{p}}, \mathrm{D}_{\text {max-p }}, \mathrm{D}_{\text {mean-u}}, \mathrm{D}_{\text {min-u }}, \mathrm{SD}_{-\mathrm{u}}\right)$. The clear influence of prognostic parameters as age, volume gland, number of needles on doses given during HDR-BRT procedure was found. Age parameter corelated with increasing value of $\mathrm{D}_{\text {max-p }}$ i $\mathrm{BED}_{\text {max-p }}$ (II group) and decreasing of $\mathrm{V}_{100-\mathrm{p}}$ (also II), $\mathrm{V}_{150-\mathrm{p}}, \mathrm{V}_{120-\mathrm{p}}, \mathrm{D}_{\text {min- } \mathrm{r}}, \mathrm{BED}_{\text {min-r }}$ (III). Increasing prostate gland volume caused higher doses and volume parameters $\mathrm{D}_{90-\mathrm{p}}, \mathrm{V}_{100-\mathrm{p}}$ in every scheme, higher doses $\mathrm{D}_{10-\mathrm{r}}, \mathrm{BED}_{10-\mathrm{r}}, \mathrm{D}_{\text {mean-r } \mathrm{r}}, \mathrm{BED}_{\text {mean-r }}, \mathrm{D}_{\text {max-u }}, \mathrm{BED}_{\text {max-u }}$ in II group, higher doses $\mathrm{V}_{100-\mathrm{u}}, \mathrm{D}_{\text {mean-u}}, \mathrm{BED}_{\text {mean- }}$ u in I. The more needles I used during procedure the higher doses $\mathrm{D}_{90-\mathrm{p}}, \mathrm{BED}_{90-\mathrm{p}}, \mathrm{V}_{100-\mathrm{p}}$ were achieved in I group, the lower values of $\mathrm{V}_{200-\mathrm{p}}, \mathrm{V}_{100-\mathrm{r}}$ were observed in the same group of patients. There was also clear correlation between needles number and doses $\mathrm{D}_{\text {max-u }}$ i $B E D_{\text {max- }}$ in II group, volumes $\mathrm{V}_{150-\mathrm{p}}, \mathrm{V}_{120-\mathrm{p}}, \mathrm{V}_{100-\mathrm{p}}$ in III. 
Conclusions: 1 . The dose in reference volume had a tendency to be lower after correction of dose-volume of organs at risk (rectum and urethra). The higher fraction dose is given, the higher risk of unexpected dose-volume in prostate and rectum/urethra reveals.

2. Trend of decreasing values of doses in target volume to protect organs at risk may cause less beneficial dosevolume histogram in the treatment area.

3. In the III group increasing age parameter was correlated with better dose arrangement. In the II group of younger patients there was a slight tendency to decrease dose-volume parameters in the reference target and to increase in rectum and urethra volume. Better dose arrangement in prostate gland correlated well with increasing initial volume of prostate gland in every scheme group. It was caused by greater number of needle applicators used in I and II group of patients. In monotherapy scheme I noted higher risk of increasing doses inside treated area of prostate gland.

4. There was a correlation between initial prognostic parameters (age, gland volume, number of needles) and dose-volume parameters of HDR-BRT procedure of reference area and organs at risk.

These observation suggests increasing risk of unsatisfactory results in prostate dose cover in young men group of patients with relatively small volume of the gland. 


\section{Wstęp}

\subsection{Rak gruczołu krokowego - epidemiologia, objawy, diagnostyka, podstawowe metody leczenia}

Epidemiologia wczesnego raka gruczołu krokowego (PCa - prostate cancer) dotyczy coraz większej grupy chorych. Znaczący wzrost wykrywalności wczesnego nowotworu tego gruczołu obserwujemy ze względu na większą dostępność badań przesiewowych, rozwój oświaty zdrowotnej oraz wzrost średniej długości życia mężczyzn. W latach 1991 do $2000 \mathrm{w}$ Polsce zanotowano znaczący wzrost zapadalności na raka gruczołu krokowego o 53\% (standaryzowany współczynnik zapadalności wzrósł z 12,2 do 18,7). W tym samym czasie stopniowo rosła śmiertelność (współczynnik śmiertelności swoistej wzrósł z 10,1 do 12,6 o 26\%) [1,2]. O szybkim wzroście zachorowalności na PCa świadczy fakt, że w ciągu ostatnich 5 lat rozpoznano na całym świecie 1,6 mln nowych przypadków. W Polsce zachorowalność po roku 2000 nadal rośnie od 5049 do 7154 w 2006 (11,2 \%) wszystkich nowotworów [3]. Równolegle z roku na rok notuje się mniej zgonów spowodowanych rozsianym procesem nowotworowym w stosunku do zwiększonej zachorowalności (2006 r - 3681-7,1\% zgonów z powodu PCa) [3]. Według danych Krajowego Rejestru Nowotworów w Wielkopolsce w latach 1999/2006 liczba chorych podwoiła się i w 2006 wyniosła 737 chorych [4]. Rak gruczołu krokowego stał się w Polsce, po raku płuca, drugim nowotworem pod względem zachorowalności u mężczyzn [3].

Objawy PCa początkowo przez wiele lat mogą rozwijać się bezobjawowo. Jedyną skuteczną i dostępną metodą jego wykrycia jest wtedy skriningowe badanie poziomu swoistego antygenu sterczowego (PSA). Nowotwór gruczołu krokowego w około 70-80\% obserwowanych przypadków rozwija się w strefie obwodowej nie dając objawów klinicznych przez długi czas [5]. Płat obwodowy gruczołu jest wprawdzie dostępny badaniu palpacyjnemu przez odbytnicę, ale częsty u pacjentów w starszym wieku łagodny przerost (BPH - ang. benign prostate hyperplasia), nie jest jednoznaczny z chorobą nowotworową i nie wskazuje na konieczność biopsji diagnostycznej. Zmiana nowotworowa powiększając się może powodować objawy uciskowe na cewkę moczową takie jak częstomocz, osłabienie strumienia czy nagłą konieczność oddawania moczu [5]. U mężczyzn młodych, u których rak rozwija się bez towarzyszącego przerostu BPH, guz w obrębie gruczołu często rośnie w sposób niemy objawowo i wykrywany jest w stadium bardziej zaawansowanym. Rozwijając się dalej 
przekracza torebkę narządu, nacieka pęcherzyki nasienne, cewkę moczową oraz tkanki miękkie i okoliczne narządy (pęcherz moczowy, odbytnicę). Nowotwór w obrębie gruczołu ma charakter wieloogniskowy a poza jego torebką często szerzy się wzdłuż przestrzeni okołonerwowych [5]. Infiltracja pęcherza moczowego i cewki może powodować krwiomocz, natomiast naciekanie szyi, trójkąta pęcherza czy ujść moczowodowych przyczynia się do powstawania zastoju w drogach moczowych, wodonercza i niewydolności nerek. Naciek odbytnicy może powodować ból podczas oddawania stolca i krwawienie z odbytu. Objawami choroby nowotworowej miejscowo zaawansowanej, często dla niej nieswoistymi, mogą być ponadto bóle w okolicy krocza, zaburzenia wzwodu, bolesne oddawanie moczu, uczucie niepełnego wypróżnienia pęcherza, krew w nasieniu czy bolesne parcie na stolec. Przerzuty odległe raka gruczołu krokowego przenoszą się drogą naczyń krwionośnych, głównie do kości (kręgosłup, miednica, żebra, kości kończyn dolnych), rzadziej do wątroby, płuc i mózgu. Zmiany przerzutowe w obrębie kośćca mają z reguły charakter osteoblastyczny i powodują przede wszystkim dolegliwości bólowe, często mylone z bólami reumatycznymi, pourazowymi bądź zwyrodnieniowymi. Niekiedy na plan pierwszy wysuwają się objawy neurologiczne (związane głównie z kompresją rdzenia kręgowego) lub objawy ogólne wynikające z hiperkalcemii i supresji szpiku kostnego [5]. Przerzuty z gruczołu do węzłów zasłonowych, okołoaortalnych, pachwinowych (cecha N) rozwijają się drogą naczyń chłonnych i są z reguły bezobjawowe.

W diagnostyce raka gruczołu krokowego tradycyjnie wymienia się podstawową triadę diagnostyczną (badanie per rectum - DRE, badania poziomu PSA oraz transrektalną ultrasonografię - TRUS z biopsja). Wartość badania DRE z powodu coraz nowszych i bardziej czułych badań obrazowych jest kontrowersyjna, ale pozwala w około $75 \%$ przypadków stwierdzić stwardnienie gruczołu lub jego asymetrię. Rozpoznanie PCa obserwuje się po wykonaniu dalszych badań diagnostycznych u 10-40\% chorych, zaleca się więc badanie DRE u wszystkich mężczyzn po 50 roku życia [5]. Poziom swoistego antygenu sterczowego (PSA) przekraczający w surowicy krwi 4 ng/ml sugeruje obecność raka (powszechnie przyjęta górna granica prawidłowego poziomu PSA). W ostatnich latach, szczególnie u młodszych mężczyzn poniżej 65 roku życia, postuluje się aby poszukiwać nowotwór w obrębie gruczołu już przy poziomie PSA 2,5 - $3 \mathrm{ng} / \mathrm{ml}$, co może, ze względu na agresywniejszy charakter rozwoju choroby, skrócić czas od rozpoznania do leczenia [5]. Aby poprawić wartość diagnostyczną swoistego antygenu sterczowego stosuje się opcjonalnie gęstość PSA (tzw. PSAD), czyli stosunek poziomu markera do objętości gruczołu (norma poniżej 0,15). Zmiana poziomu PSA w czasie (tzw. szybkość narastania - PSAV) o 20\% 
wartości wyjściowej również sugeruje konieczność pogłębienia diagnostyki w kierunku nowotworu [6]. Duże znaczenie ma poziom tzw. wolnego PSA i jego stosunek do PSA całkowitego (wartość w warunkach prawidłowych nie powinna być niższa niż 0,18 ) [6]. Transrektalna ultrasonografia (TRUS) pozwala na ocenę struktury i granic gruczołu krokowego oraz ryzyko naciekania narządów sąsiadujących (stopień zaawansowania miejscowego - T) [5]. Cechą charakterystyczną nowotworu złośliwego jest zazwyczaj wieloogniskowy twór hipoechogenny w strefie obwodowej, dodatkowo wykazujący wzmożone unaczynienie w badaniu Doppler - USG [7]. Dodatkowymi informacjami, dostępnymi po badaniu może być obecność zwapnień w miąższu, objętość gruczołu, jego kształt i położenie oraz przebieg cewki moczowej w stosunku do opisywanych zmian nowotworowych. Są one szczególnie ważne wobec dalszej diagnostyki (biopsja) i decyzji o leczeniu zabiegowym bądź zachowawczym [8]. Ostateczne rozpoznanie raka gruczołu krokowego umożliwia biopsja gruboigłowa pod kontrolą ultrasonografu przezodbytniczego za pomocą igły TRU-CUT. Pobiera się z obu stref obwodowych po 3 wycinki, aby zwiększyć prawdopodobieństwo znalezienia komórek raka. W przypadku wysokiego prawdopodobieństwa procesu nowotworowego (wysoki wyjściowy poziom PSA, badanie kliniczne, badania obrazowe) oraz decyzji o braku leczenia radykalnego, dopuszczalne jest wykonanie biopsji aspiracyjnej cienkoigłowej z oceną cytologiczną [5]. Rak gruczołowy jest rozpoznawany w 75-98\% wykonywanych biopsji diagnostycznych. Mikroskopowo cewy gruczołowe i pęcherzyki ułożone są gęsto, komórki pęcherzyków w jednej warstwie a komórki nowotworowe mają obfita, słabo barwiącą się cytoplazmę, jądro o dużym kwasochłonnym jąderku [8]. Stopień zróżnicowania komórkowego i złośliwości histologicznej określa się na podstawie badania rdzeni tkankowych i podaje w postaci współczynnika sumy systemu Gleasona (GS - Gleason score). W skali tej, obraz raka pośród małych gruczołów z jednorodnym, regularnym utkaniem (wysoki stopień zróżnicowania) klasyfikowany jest jako 1 punkt, natomiast brak utkania gruczołowego ze skupiskami komórek nowotworowych jako 5 punktów (rak nisko zróżnicowany, wysoce złośliwy). Dwa miejsca po biopsji rozpoznane jako punkty o najwyższej złośliwości, ocenione w punktacji GS i zsumowane dają ostateczny stopień zróżnicowania komórkowego [9]. Skala przekłada się na wyodrębnienie grup rokowniczych, obejmuje punktację od 2-10, gdzie 2-6 odpowiada komórkom dobrze zróżnicowanym i grupie niskiego ryzyka, natomiast 8-10 komórkom niezróżnicowanym i grupie ryzyka wysokiego [9]. Do rzadko występujących nowotworów gruczołu krokowego, o utkaniu innym niż gruczołowe, należą rak przejściowokomórkowy, rak płaskonabłonkowy, mięsaki stercza (rhabdomyosarcoma, leiomyosarcoma) a także 
nowotwory wywodzące się z tkanki nerwowej, chłonnej [10]. Badaniami uzupełniającymi w diagnostyce PCa, pozwalającymi na ostateczne określenie zaawansowania procesu (skala TNM) i warunkujących wybór metody leczenia są: tomografia komputerowa lub rezonans miednicy mniejszej, scyntygrafia koścca, limfadenektomia zaotrzewnowa. Klasyfikacja stopnia zaawansowania opiera się na klasyfikacji TNM AJCC/UICC z 2002 roku (Tabela 1) [11].

Tabela 1. TNM wg AJCC/UICC 2002 [11]

\begin{tabular}{|c|c|}
\hline Cecha & Charakterystyka \\
\hline$\underline{\mathbf{T}}$ & Guz pierwotny \\
\hline Tx & Nie można ocenić guza pierwotnego \\
\hline T0 & Nie ma dowodów na istnienie guza pierwotnego \\
\hline $\mathrm{T} 1$ & $\begin{array}{l}\text { Guz klinicznie niejawny, nie stwierdza się go na podstawie badania klinicznego } \\
\text { ani badań obrazowych }\end{array}$ \\
\hline T1a & $\begin{array}{l}\text { Guz wykryty przypadkowo na podstawie badania histopatologicznego w } \\
\text { najwyżej 5\% wyciętej tkanki gruczołu krokowego. }\end{array}$ \\
\hline $\mathrm{T} 1 \mathrm{~b}$ & $\begin{array}{l}\text { Guz wykryty przypadkowo na podstawie badania histopatologicznego w ponad } \\
5 \% \text { wyciętej tkanki gruczołu krokowego. }\end{array}$ \\
\hline T1c & $\begin{array}{l}\text { Guz rozpoznany na podstawie biopsji (wykonanej z powodu wzrostu stężenia } \\
\text { PSA w surowicy) }\end{array}$ \\
\hline $\mathrm{T} 2$ & Guz ograniczony do gruczołu krokowego \\
\hline $\mathrm{T} 2 \mathrm{a}$ & Guz zajmuje $\leq 1 / 2$ jednego płata \\
\hline $\mathrm{T} 2 \mathrm{~b}$ & Guz zajmuje $>1 / 2$ jednego płata \\
\hline $\mathrm{T} 2 \mathrm{c}$ & Guz zajmuje oba płaty \\
\hline $\mathrm{T} 3$ & Guz nacieka poza torebkę gruczołu krokowego \\
\hline T3a & Naciekanie poza torebkę (jednostronne lub obustronne) \\
\hline $\mathrm{T} 3 \mathrm{~b}$ & Naciekanie pęcherzyków nasiennych. \\
\hline $\mathrm{T} 4$ & $\begin{array}{l}\text { Guz jest nieruchomy lub nacieka tkanki okoliczne inne niż pęcherzyki nasienne } \\
\text { (szyję pęcherza, zwieracz zewnętrzny cewki moczowej, odbytnicę, mięsień } \\
\text { dźwigacz odbytu i/lub ścianę miednicy) }\end{array}$ \\
\hline $\mathbf{N}$ & Okoliczne (regionalne) wezły chłonne \\
\hline $\mathrm{Nx}$ & Nie można ocenić okolicznych węzłów chłonnych \\
\hline No & Nie stwierdza się przerzutów w okolicznych węzłach chłonnych \\
\hline N1 & Stwierdza się przerzuty w okolicznych węzłach chłonnych \\
\hline $\mathbf{M}$ & Przerzuty odległe \\
\hline Mx & Nie można ocenić przerzutów w odległych narządach \\
\hline M0 & Nie stwierdza się przerzutów w odległych narządach \\
\hline M1 & Stwierdza się przerzuty w odległych narządach \\
\hline M1a & Przerzuty w jednym lub wielu pozaregionalnych węzłach chłonnych \\
\hline M1b & Przerzuty do kości \\
\hline M1c & Przerzuty o innym umiejscowieniu \\
\hline
\end{tabular}


Podstawowymi metodami leczenia nowotworów w tej lokalizacji ciagle pozostają zabieg operacyjny (usunięcie gruczołu wraz z guzem całkowicie, w różnych modyfikacjach) oraz radioterapia [12]. Wymienione wyżej dwa sposoby leczenia różnią się od siebie występowaniem i skalą objawów niepożądanych wobec podobnej skuteczności, udowodnionej w badaniach randomizowanych [13,14]. Informacje dotyczące chorób współistniejących, wieku biologicznego chorych, spodziewanego ich czasu przeżycia oraz preferencji pacjenta wpływają na decyzję o leczeniu zabiegowym, radioterapii bądź nawet tzw. czujnej obserwacji (ang. watchful waiting) [14]. Głównym kryterium zakwalifikowania pacjenta do wybranej metody leczenia, pozostaje jednak stopień zaawansowania miejscowego nowotworu i brak przerzutów odległych (TNM). Pacjenci z rakiem miejscowo zaawansowanym, $\mathrm{z}$ naciekiem na pęcherzyki nasienne lub sąsiednie narządy, rzadko poddawani są zabiegowi operacyjnemu, zwykle są kwalifikowani do radioterapii. W doborze leczenia chorych ważną rolę pełnią grupy ryzyka, do których mężczyźni z rakiem gruczołu krokowego powinni być kwalifikowani na podstawie stopnia zaawansowania, zróżnicowania komórkowego oraz poziomu wyjściowego antygenu PSA [5]. Podstawowe grupy ryzyka chorych na PCa przedstawiono $\mathrm{w}$ tabeli 2. Pacjenci z przerzutami odległymi powinni być leczeni paliatywnie hormonoterapią lub chemioterapią wraz z krótkotrwałą radioterapią miejsc przerzutowych w układzie kostnym [5].

Tabela 2. Grupy ryzyka raka gruczołu krokowego (N0,M0) [15].

\begin{tabular}{|l|l|l|l|}
\hline & $\begin{array}{l}\text { Grupa niskiego } \\
\text { ryzyka }\end{array}$ & $\begin{array}{l}\text { Grupa } \\
\text { pośredniego } \\
\text { ryzyka }\end{array}$ & $\begin{array}{l}\text { Grupa } \\
\text { wysokiego } \\
\text { ryzyka }\end{array}$ \\
\hline $\mathrm{T}$ & $1-2 \mathrm{a}$ & $2 \mathrm{~b}, 2 \mathrm{c}$ & $3 \mathrm{a}$ \\
\hline PSA & poniżej 10 & $10-20$ & powyżej 20 \\
\hline Gleason score & poniżej 7 & 7 & powyżej 7 \\
& & & \\
\hline
\end{tabular}


W ostatnich dwóch dekadach dzięki rozwojowi zaawansowanej technologii i komputerowych systemów planowania leczenia, renesans w leczeniu raka gruczołu krokowego przeżywa radioterapia przy użyciu wiązki zewnętrznej (ang. external beam radiation therapy - EBRT) oraz brachyterapia. Zmiany dobrze zlokalizowane, widoczne $\mathrm{w}$ badaniach obrazowych $\mathrm{i}$ niepodejrzane o przerzuty próbuje się leczyć miejscowo za pomocą termoablacji (krioterapii), wiązką ultradźwięków o wysokiej intensywności (HIFU) lub ablacją laserową (ILA) [16,17]. Istotne miejsce w leczeniu PCa, zajmuje leczenie hormonalne pod postacią częściowej lub całkowitej blokady androgenowej. W grupach pośredniego i wysokiego ryzyka hormonoterapię stosuje się jako leczenie neoadjuwantowe i adiuwantowe, odpowiednio w grupach trwające 4-6 miesięcy i 2-3 lat [18]. W grupie niskiego ryzyka blokada hormonalna, poza zastosowaniem celem uwrażliwienia komórek na promieniowanie jonizujące lub zmniejszenia objętości gruczołu (terapia neoadiuwantowa), nie ma zastosowania [18]. W ostatnich latach prowadzi się także badania nad chemioterapią (docetaksel) w leczeniu raka gruczołu krokowego. Leczenie systemowe zarezerwowane powinno być dla raka przerzutowego, hormonoopornego (ang. hormone resistant prostate carcinoma - HRPC) w przypadku niepowodzenia wszystkich dostępnych metod [19].

\subsection{Leczenie chirurgiczne}

Historia radykalnej prostatektomii sięga roku 1904, kiedy amerykański chirurg Hugh Hampton Young po raz pierwszy wykonał i opisał usunięcie gruczołu krokowego droga przezkroczową [20]. Usunięcie gruczołu krokowego z dostępu nad spojeniem łonowym, wykonał w 1949 r. Memelaar, w późniejszym czasie konieczna okazała się modyfikacja zabiegu, dokonana przez Welsha z powodu dużej częstotliwości powikłań pooperacyjnych [21]. Historyczną metodą, aktualnie bardzo rzadko stosowaną, był dostęp przez kość guziczną. Droga przez krocze zyskuje ponownie po wielu latach zwolenników a do zalet takiego postępowania należą: mniejsza utrata krwi, łatwiejsze warunki anatomiczne w czasie wykonania zespolenia pęcherzowo-cewkowego oraz znacznie mniejsze prawdopodobieństwo uszkodzenia odbytnicy [10]. Z kolei zaletą dostępu załonowego pozostaje możliwość usunięcia węzłów chłonnych i ich ocena śródoperacyjna, w trakcie tego samego zabiegu. Radykalna prostatektomia różni się od zabiegu adenomektomii, będącej wycięciem gruczolaka stercza $\mathrm{z}$ pozostawieniem torebki gruczołu (w literaturze angielskiej zwana prostatektomia) usunięciem gruczołu wraz z pęcherzykami nasiennymi [21]. Metodą szybko rozwijającą się, o najmniejszej inwazyjności, wydaje się być laparoskopowe usunięcie 
gruczołu krokowego, wymagające dużych umiejętności i kosztownego sprzętu [21]. Alternatywną metodą chirurgiczną do powyżej wymienionych, jest w wybranych przypadkach przezcewkowa resekcja gruczołu (TUR-P). Pozwala ona na częściowe usunięcie miąższu, wraz z przylegającym do cewki moczowej skupiskiem podejrzanych komórek [22]. Głównym warunkiem kwalifikacji do zabiegu radykalnego pozostaje wczesne zaawansowanie kliniczne (nowotwór umiejscowiony w obrębie gruczołu) a powodzenie leczenia uzależnione jest od jego radykalności. Kwestią sporną pozostaje rola hormonoterapii w obniżeniu stopnia zaawansowania nowotworu, w guzach z wyjściowym zaawansowaniem klinicznym T3,T4. Operacja w stopniu T3a zalecana jest jedynie przy poziomie PSA poniżej $20 \mathrm{ng} / \mathrm{ml}$ i stopniu złośliwości w skali GS poniżej 8, co stwarza dużą szansę doszczętności zabiegu. Wykonanie prostatektomii $\mathrm{w}$ przypadkach bardziej zaawansowanych nie jest zalecane, ponieważ nie wydłuża czasu przeżycia pacjenta [23]. Oprócz czynników związanych z samym nowotworem zasadność leczenia chirurgicznego jest uzależniona od wieku chorych, ich stanu ogólnego oraz chorób towarzyszących. Biorąc pod uwage powolny wzrost PCa oraz fakt podeszłego wieku u większości mężczyzn, do prostatektomii powinni być kierowani chorzy z przewidywanym czasem przeżycia, co najmniej 10 - letnim [21]. Wyniki prostatektomii są zależne od czynników rokowniczych, przeżycie odległe wynoszą 70-90\% (5 lat obserwacji), 50 - 70\% (10 lat) i 30 - 50\% (15 lat) [24, 25]. Niezależnie od różnic w jakości życia, porównanie przeżyć 5 i 10 letnich po zabiegu operacyjnym i radioterapii raka gruczołu krokowego wskazuje na równoważność tych metod [12,13]. Istotną różnicą pozostaje odsetek i rodzaj powikłań, do których w przypadku prostatektomii należą przede wszystkim wczesne powikłania zakrzepowo-zatorowe (zakrzepica żylna - 3-12\%, zatorowość płucna - 2-5\%, limfocele). Powikłania śródoperacyjne obejmują krwawienie (ze splotu Santoriniego), uszkodzenie ściany odbytnicy lub moczowodów. Do częstych, późnych powikłań tej metody zaliczamy nietrzymanie moczu, zwężenie połączenia cewkowo-pęcherzowego oraz impotencję [10]. Oszczędzenie pęczka naczyniowo-nerwowego po obu stronach pozwala zachować erekcję u $63 \%$ mężczyzn i u $41 \%$ jeżeli był on przecięty po jednej ze stron [10]. Powikłania po zabiegu TUR-P wynoszą średnio: krwawienie (1,5\%), zatorowość płucna $(0,2 \%)$, uszkodzenie szyi pęcherza $(14 \%)$, nietrzymanie moczu $(0,6 \%)$, impotencja $(30 \%)$ [22]. 


\subsection{Radioterapia przy użyciu wiązek zewnętrznych}

Coraz częściej chorych na PCa leczy się różnymi technikami radioterapii. Dawkę promieniowania jonizującego podaje się techniką wiązki zewnętrznej (EBRT - ang. external beam radiation therapy) albo brachyterapii śródtkankowej. Do napromieniania wiązką zewnętrzną nadają się chorzy z potwierdzonym mikroskopowo rakiem gruczołu krokowego, zarówno $\mathrm{z}$ nowotworem zlokalizowanym wewnątrz gruczołu jak $\mathrm{i}$ regionalnie zaawansowanym (naciek poza torebkę). Wyniki 15-letnie radioterapii chorych na raka gruczołu krokowego, w zależności od stopnia zaawansowania klinicznego wynoszą: T1 85\%, T2 - 65-68\%, T3 - 44-75\% [26,27]. Możliwe powikłania po EBRT najczęściej dotyczą układów pokarmowego i moczowego. Częstotliwość występowania ciężkich owrzodzeń i przewlekłego, popromiennego zapalenia odbytnicy, wymagających dalszej interwencji chirurgicznej, nie przekracza 2-3\% [10]. W większości przypadków, dominują objawy podrażnienia błony śluzowej w stopniu małym i średnim, ustępują po 2-3 miesiącach od zakończonego leczenia. Ciężkie, późne powikłania ze strony układu moczowego obserwuje się u 1-2\% chorych, najczęściej pod postacią owrzodzenia lub zwłóknienia pęcherza moczowego i zwężenia cewki. 50\% pacjentów odczuwa ostre dolegliwości dyzuryczne, z dolegliwościami bólowymi i wzmożoną częstotliwością oddawania moczu [10]. U 2-4\% chorych stwierdza się ostre zatrzymanie moczu, nietrzymanie moczu, krwiomocz. W przeciwieństwie do leczenia operacyjnego, odsetek mężczyzn z impotencją jest znacząco mniejszy i wynosi średnio $20 \%$ [28].

Miejscowe wyleczenie raka gruczołu krokowego zależy od wielkości podanej dawki całkowitej oraz od sposobu jej frakcjonowania. Zauważono, że im wyższa dawka całkowita podana na okolicę gruczołu, tym odsetek kontroli miejscowej nowotworu jest wyższy [14]. Eskalacja dawki okazała się przez długie lata niewykonalna, ze względu na towarzyszące leczeniu napromienianie zdrowych narządów w otoczeniu gruczołu, przy użyciu dwuwymiarowych technik radioterapii. Stosowane jeszcze w latach osiemdziesiatych aparaty kobaltowe umożliwiały podanie promieniowania jonizującego w ciągu 6-7 tygodni do dawki 64-66 Gy, w technice czterech prostokątnych pól (ang. box) [29].

Zaobserwowano, że w czterech przedziałach dawek (60 Gy, 60-64 Gy, 65 - 69 Gy, powyżej $70 \mathrm{~Gy}$ ), odsetek wznów miejscowych był mniejszy, wraz ze wzrostem dawki całkowitej (odpowiednio 37, 36, 28 i 19\%) [30]. Dużą nadzieję na podanie dawki wyższej bez zwiększenia ryzyka komplikacji wiązano $\mathrm{z}$ rozwojem radioterapii konformalnej, trójwymiarowej (3D CRT). Jako technika pozwalająca na eskalcję dawki została porównana w badaniu randomizowanym $\mathrm{z}$ konwencjonalną radioterapią. Jego 5-letnie wyniki 
potwierdziły przypuszczenia, że dawka 78 Gy podana techniką 3D CRT powoduje większe prawdopodobieństwo przeżycia bez nawrotu choroby (79\%), w porównaniu z dawką 70 Gy w technice konwencjonalnej (70\%) [31]. Podobny profil toksyczności popromiennej odbytnicy w obu ramionach badania podniósł znaczenie metody konformalnej w leczeniu chorych. Kolejnym etapem postępu w radioterapii gruczołu krokowego było wprowadzenie techniki napromieniania z tzw. intensywną modulacją wiązki IMRT (ang. intensity modulated radiation therapy). Metoda ta, poprzez komputerowe sterowanie intensywnością dawki promieniowania dla każdej z wiązek podczas cyklu, umożliwia dalsze zmniejszanie pola napromienianego (ochrona narządów) i wzrost wielkości zastosowanych dawek na guz w obrębie gruczołu [14]. Przeprowadzone badania wykazały zmniejszenie objętości dawek w odbytnicy oraz częstotliwości krwawień w porównaniu z napromienianiem 3D CRT (2\% vs 10\%) [32, 33]. Kolejnym krokiem w rozwoju radioterapii jest technika radioterapii kierowanej obrazem IGRT (ang. image guided radiation therapy) [34]. Wada poprzednich sposobów napromieniania pacjentów było nieuwzględnienie faktu przemieszczenia organów wewnętrznych otaczających gruczoł, pomiędzy frakcjami leczenia. Wprowadzenie IGRT dodaje do trójwymiarowego planowania leczenia czwarty wymiar, eliminując ryzyko późnych odczynów popromiennych, niewynikających $\mathrm{z}$ błędów $\mathrm{w}$ procesie planowania lub codziennego ułożenia chorego w trakcie radioterapii. Radioterapia IGRT wykorzystuje dwu lub trójwymiarowe obrazy rtg, tomografu komputerowego w celu weryfikacji aktualnego położenia gruczołu wraz z narządami okolicznymi przed każdą frakcją [35].

Oprócz rozwoju technologicznego i stopniowego zwiększenia dawki promieniowania jonizującego, kierunki badań nad poprawą wyników leczenia skoncentrowały się także nad sposobem jej frakcjonowania oraz skróceniem całkowitego czasu terapii. Określenie przybliżonej wartości współczynnika alfa/beta $(\alpha / \beta)$ niezbędne do obliczeń biologicznej dawki efektywnej (BED) dla raka gruczołu krokowego skłoniły badaczy do eksperymentowania $\mathrm{z}$ wyższymi dawkami frakcyjnym (tzw. hipofrakcjonowanie). Nowotwory szybciej proliferujące mają wartości $\alpha / \beta$ wyraźnie wyższe, wymagają częstych ale niskich dawek frakcyjnych celem regresji guza i przezwyciężenie efektu repopulacji przy minimalnym ryzyku ciężkich powikłań popromiennych [36]. Rak gruczołu krokowego należy do guzów proliferujących wolno, ma niższą wartość współczynnika od narządów okolicznych, stąd jest bardziej wrażliwy na zmianę dawki frakcyjnej i wymaga podawania dawek wyższych w krótszym czasie leczenia [36]. Od czasu prac opublikowanych przez Brennera i Halla w 1999 r. (określili wartość współczynnika $\alpha / \beta$ jako 1,5 Gy) nie udało się ustalić dokładnej jego wartości [37]. Nie wiadomo ile wynosi wartość $\alpha / \beta$ dla błony śluzowej 
odbytnicy oraz dla pęcherza moczowego (prawdopodobnie jest to poziom 3-5 Gy). Niską wartość współczynnika potwierdzili Wang i współpracownicy w 2003 r. (około 3,1 Gy), odbiegając jednak od wyników uzyskanych w pracy Brennera i Halla [38]. Opublikowano wyniki trzech badań randomizowanych, porównujących hipofrakcjonowanie dawki po 2,62,7 Gy/dobę z konwencjonalną radioterapią po 2 Gy i wyższą dawką całkowitą podawaną w dłuższym czasie leczenia [39,40,41]. Metody okazały się porównywalne pod kątem efektywności leczenia przy nieznacznym wzroście ryzyka ostrego odczynu popromiennego ze strony układu moczowego przy hipofrakcjonowaniu. Autorzy nie wykluczyli jednak możliwości zysku terapeutycznego przy zastosowaniu nowych metod frakcjonowania i użycia nowych technologii w napromienianiu pacjentów. Aktualnie trwa wiele badań randomizowanych, w różnych grupach ryzyka, które mają odpowiedzieć na pytanie o przydatność alternatywnego sposobu frakcjonowania, także przy udziale brachyterapii (triale Fox Chase, MRC, NCIC, RTOG 0415). Wzrost częstotliwości ostrych powikłań ze strony układu moczowego w leczeniu skojarzonym wykazał Ishiyama i współpracownicy [42]. W schemacie EBRT (10 x 3 Gy) + HDR-BRT (5 x 6 Gy) przyczyną wysokiego odsetka powikłań (6\% ostrych powikłań i 12\% przewlekłych) była wysoka dawka deponowana w obrębie cewki moczowej podczas leczenia. Im większa objętość cewki w obszarze wysokiej dawki, tym większe stwierdzono prawdopodobieństwo powikłań ze strony układu moczowego pod postacią nietrzymania moczu i zwężeń. Objętość prostaty, wiek, punktacja w skali IPSS nie miały wpływu na częstość powikłań [42].

\subsection{Brachyterapia HDR raka gruczołu krokowego - rys historyczny}

Brachyterapia stosowana jako uzupełnienie dawki (tzw. boost) jest doskonałą techniką która łączy próbę poprawy precyzji napromieniania gruczołu krokowego wysoką dawką, z ideą hipofrakcjonowania. Stosując tę metodę w obrębie miednicy mniejszej, zwłaszcza w monoterapii, trzeba pamiętać o wysokich, biologicznych dawkach efektywnych i poważnej konsekwencji błędów geograficznych podczas procesu planowania leczenia. Pierwsze doniesienia na temat brachyterapii PCa datuje się na rok 1911. Wówczas Paschis jako pierwszy opracował cystoskopowy aplikator za pomocą którego, umieszczał kapsułkę radową w obrębie gruczołu krokowego [19]. Równolegle Pasteau i Degrais w Paryżu opisywali technikę bezpośredniej aplikacji źródła umieszczonego zwykłym, gumowym cewnikiem przez cystoskop. Metodą przezkroczowego zakładania radu zajmował się Benjamin Barringer, 
który implantował materiał za pomocą igieł lub pod postacią złotych kapsułek, opisując ją po raz pierwszy w $1917 \mathrm{r}$ [43]. W latach $30 \mathrm{XX}$ wieku prowadził także badania nad brachyterapią $\mathrm{z}$ dostępu nadłonowego a ziarna radowe wszczepiał w trakcie zabiegu operacyjnego, po odsłonięciu gruczołu. Stosując techniki zarówno nadłonowego i kroczowego dostępu opracował płytkę celownicza, podobną do obecnie używanych. Kontynuatorem prac Barringera okazał się Hugh H. Young, który w swoim instytucie w Baltimore stosował brachyterapię, implantując źródło przez pęcherz lub odbytnicę, opracowanym przez siebie aplikatorem radowym [44]. W połowie XX wieku raka gruczołu krokowego starano się leczyć koloidalnym roztworem złota radioaktywnego, wstrzykiwanego drogą przezkroczową oraz przezpęcherzowo a dokonał tego po raz pierwszy Rubin Flocks z Uniwersytetu Stanowego w Iowa. Pionierem w zakresie brachyterapii o niskiej mocy dawki okazał się być Willet W. Whitmore jr., stosujący jednoczasową miedniczną limfadenektomię z implantacją źródeł jodowych (I-125) drogą nadłonową [45]. Okres zastoju w historii brachyterapii, obserwowany $\mathrm{w}$ połowie wieku XX zakończył się w momencie odkrycia ultrasonografu przezodbytniczego przez Watanabe, który uzyskał pierwsze, użyteczne w planowaniu radioterapii tomogramy miednicy mniejszej [46]. Na tej podstawie duńczycy Holm i Gammelgaard przeprowadzili w 1983 r aplikację ziaren jodu pod kontrolą obrazu transrektalnego usg, wcześniej stosując tą metodę obrazowania w biopsji gruczołu krokowego [47]. Aktualną brachyterapię z zastosowaniem Irydu (Ir-192) jako pojedyńczego źródła kroczącego, w technice następczego ładowania (ang. afterloading) zawdzięczamy Bertermannowi, który wraz z współpracownikami zastosował ją na Uniwersytecie w Kilonii w 1985 r [48]. Zdalne ładowanie źródła spowodowało istotną redukcję napromieniania personelu podczas każdej frakcji leczenia.

\subsection{Brachyterapia HDR raka gruczołu krokowego - opis metody}

Leczenie pacjentów z rakiem gruczołu krokowego, metodą samodzielną lub skojarzonej z EBRT brachyterapii, jest doskonałym przykładem idei leczenia konformalnego i hipofrakcjonowania dawki. Przy zastosowaniu tej metody napromieniania ,z bliska” (grec. brachio) wykorzystywana jest energia rozpadu źródeł promieniotwórczych, implantowanych w bezpośrednie sąsiedztwo guza na czas określony (implanty czasowe - Ir-192) lub na stałe (permanentna brachyterapia - I-125, Pd-103, Cs-131). Brachyterapię PCa, ze względu na sposób dostarczenia źródła zaliczymy do metod śródtkankowych. Napromienianie 
śródtkankowe raka gruczołu krokowego dzielimy ponadto ze względu na moc dawki promieniowania i wyróżniamy brachyterapię o niskiej mocy dawki (LDR - low dose rate) oraz o wysokiej mocy dawki (HDR - high dose rate) [49]. Zakres mocy dawek wykorzystywanych podczas leczenia $\mathrm{w}$ powyższych rodzajach promieniowania wynosi odpowiednio: $0,01-0,3 \mathrm{~Gy} / \mathrm{h}$ oraz $>12 \mathrm{~Gy} / \mathrm{h}$. Implanty cechujące się niską mocą dawki zakłada się do gruczołu na stałe, podczas jednorazowego zabiegu operacyjnego drogą przezkroczową. Charakter emisji promieniowania jonizującego i jego wolne, długotrwałe deponowanie dawki, sugeruje jego zastosowanie u pacjentów $\mathrm{z}$ nowotworem wolno rozwijającym się, u których poważna eskalacja dawki i ryzyko ciężkich powikłań popromiennych są nieuzasadnione.

W Polsce zdecydowana większość pacjentów leczonych jest metodą implantów czasowych (HDR-BRT) głównie z powodów finansowych. Technika ta, dzięki wysokiej mocy dawki źródła irydowego wymaga krótkiego czasu leczenia (5-20 minut) bez konieczności pozostawienia na stałe wewnątrz gruczołu materiału promieniotwórczego. Wykorzystuje ona źródło Ir-192 o nominalnej aktywności 370 GBq (10 Ci) oraz o czasie połowicznego rozpadu 73,8 dni. Metoda, pomimo stosowania wysokiej mocy dawki, pozostaje bezpiecznym sposobem leczenia zarówno dla pacjenta jak i personelu medycznego. Opracowanie systemu zdalnego ładowania źródła (ang. remote afterloading) wraz z procedurami postępowania awaryjnego i ochrony radiacyjnej spowodowało możliwość wykorzystania irydu do leczenia chorych z nowotworami złośliwymi w wielu innych lokalizacjach [49].

W porównaniu do napromieniania wiązką zewnętrzną, HDR-BRT zwiększa koncentrację dawki w obrębie gruczołu krokowego, umożliwia podanie wyższych dawek frakcyjnych i wyższych dawek równoważnych biologicznie ze znacznym skróceniem czasu leczenia [47].

Zaletą HDR-BRT pozostaje szybki spadek dawki (odwrotnie proporcjonalnie do kwadratu odległości) wraz z rosnącą odległością od izotopu promieniotwórczego co skutkuje skuteczną ochroną narządów sąsiadujących z gruczołem krokowym. Ponadto w porównaniu do LDRBRT, powoduje korzystniejszy rozkład dawki i możliwość jej modyfikacji podczas zabiegu, wyższą skuteczność biologiczną (logarytmiczna zależność zabijanych komórek od mocy dawki). Dzięki zastosowaniu pomieszczeń ochronnych oraz braku konieczności ręcznego ładowania źródła ochrona radiacyjna jest zapewniona a wykorzystanie pojedyńczego, zminiaturyzowanego Ir-192 o stosunkowo długim okresie rozpadu, daje konkretne oszczędności. Z drugiej strony użycie źródeł o wysokiej mocy dawki zwiększa ryzyko ostrych i późnych odczynów popromiennych, ogranicza zasięg aktywności skutecznej, silniej 
uzależnienia prawidłowy rozkład dawki od objętości gruczołu i liczby użytych aplikatorów śródtkankowych.

Technika HDR-BRT jest dzisiaj stosowana w trybie leczenia w czasie rzeczywistym (ang. real-time treatment). Dzięki ciągłej kontroli rozkładu dawki, przed i po implantacji aplikatorów śródtkankowych do miąższu gruczołu, jest najbardziej konformalnym, obecnie dostępnym sposobem napromieniania pacjentów wysokimi dawkami frakcyjnymi. Etapem początkowym, po ułożeniu pacjenta w pozycji litotomicznej jest zebranie obrazu za pomocą transrektalnego usg (TRUS), określenie objętości gruczołu krokowego i narządów krytycznych (ang. Organs at Risk - OAR). We współpracy z fizykiem lekarz implantuje następnie w obręb miąższu aplikatory (igły) zgodnie z wcześniej wykonanym, wirtualnym planem leczenia. Ponieważ gruczoł krokowy jest narządem ruchomym, po implantacji wykonywany jest plan rzeczywisty, uwzględniający zmianę położenia organu względem pęcherza i odbytnicy podczas implantacji igieł. Aktualny postęp technologiczny umożliwia cyfrowy transfer obrazu $\mathrm{z}$ aparatów ultrasonograficznych do komputerowego systemu planowania w sposób ciągły i w czasie rzeczywistym dając dokładny obraz przestrzenny gruczołu krokowego i otaczających tkanek wraz z igłami w polu napromieniania. Ostateczny, zatwierdzony plan leczenia realizowany jest w technice tzw. źródła kroczącego implantowanego czasowo w obręb każdego z aplikatorów, według ustalonych parametrów czasu i miejsca postoju [49].

Wskazaniem do samodzielnej brachyterapii raka gruczołu krokowego jest choroba zlokalizowana, bez nacieku torebki $(\mathrm{T} 1$ - T2b) i obejmująca pacjentów z grupy niskiego ryzyka (tab.2,3). BRT-HDR w grupach pośredniego i wysokiego ryzyka jest stosowana najczęściej w skojarzeniu $\mathrm{z}$ teleradioterapią (EBRT) celem podwyższenia dawki miejscowej (tzw. boost). Rekomendacje Amerykańskiego Towarzystwa Brachyterapii nt. stosowania brachyterapii w leczeniu PCa przedstawiono w tabeli 3 [50]. Ograniczeniami techniki moga być: duża objętość gruczołu krokowego (ponad $60 \mathrm{ml}$ ), przerzuty miejscowe i odległe (N, M), poważne utrudnienia $\mathrm{w}$ oddawaniu moczu. Nie zaleca się brachyterapii u pacjentów po niedawno przeprowadzonej elektroresekcji gruczołu (TURP) ze względu na ryzyko nietrzymania moczu. Przeciwskazaniami względnie uniemożliwiającymi zabieg są: wysokie położenie gruczołu pod spojeniem łonowym, stany zapalne w jego obrębie, łagodny przerost płata środkowego oraz choroby zapalne jelit i odbytnicy [49]. 
Tabela 3. Wskazania do brachyterapii raka gruczołu krokowego (zalecenia Amerykańskiego Towarzystwa Brachyterapii) [48].

\begin{tabular}{|c|c|c|c|}
\hline Czynnik rokowniczy & $\begin{array}{l}\text { BRT zalecana } \\
\text { Rokowanie dobre }\end{array}$ & $\begin{array}{l}\text { BRT opcjonalna } \\
\text { Rokowanie dość } \\
\text { dobre }\end{array}$ & $\begin{array}{l}\text { BRT rzadko } \\
\text { stosowana } \\
\text { Rokowanie złe }\end{array}$ \\
\hline PSA (ng/ml) & $<10$ & $10-20$ & $>20$ \\
\hline Skala Gleasona & $5-6$ & 7 & $8-10$ \\
\hline Stopień T & T1c-T2a & T2b-T2c & T3 \\
\hline IPSS & $0-8$ & $40-60$ & $>60$ \\
\hline $\begin{array}{c}\text { Objętość prostaty (cm3) } \\
\text { Przepływ minimalny } \\
\text { moczu - Q min (ml/s) }\end{array}$ & $<40$ & $15-10$ & $<10$ \\
\hline $\begin{array}{c}\text { Objętość rezerwowa } \\
(\mathrm{cm} 3)\end{array}$ & $>15$ & & $>200$ \\
\hline \begin{tabular}{c} 
TURP +/- \\
\hline
\end{tabular} & & & + \\
\hline
\end{tabular}

\subsection{Brachyterapia HDR raka gruczołu krokowego - schematy frakcjonowania dawki, własne doświadczenia.}

Ze względu na brak ustaleń co do wartości współczynnika $\alpha / \beta$ dla $\mathrm{PCa}$, dawki i frakcjonowanie brachyterapii pozostają niewiadomą. Przeprowadzone badania dowiodły, że dawka całkowita porównana do frakcjonowania konwencjonalnego 2 Gy w teleradioterapii (EQD2) powinna być nie mniejsza niż 70 - 72 Gy [51]. Aktualnie metody leczenia raka gruczołu krokowego umożliwiają podanie wyższych dawek całkowitych, często łaczy się EBRT z HDR-BRT tak, aby wysokiej eskalacji dawki nie towarzyszyło zwiększone ryzyko późnych odczynów popromiennych. Wyniki leczenia pacjentów nie zależą jedynie od 
wysokości dawki promieniowania jonizującego ale także od wyjściowych parametrów prognostycznych, takich jak stopień zaawansowania klinicznego, poziom wyjściowego PSA, stopień zróżnicowania komórkowego (skala GS). Częstotliwość powikłań, głównie w postaci odczynów popromiennych w obrębie odbytnicy, silnie koreluje z wysokością podanej dawki oraz sposobem jej deponowania w różnych metodach (3D CRT - ang. 3-dimentional conformal radiotherapy, IMRT, BRT) [52]. Niewiadomą także są granice eskalowania dawki promieniowania jonizującego, szczególnie w przypadku samodzielnej HDR-BRT, stosowanej w najniższej grupie ryzyka o generalnie dobrym rokowaniu. Od wielu lat badacze opisują dobre wyniki po radioterapii raka gruczołu krokowego, pomimo zastosowania różnorodnych metod frakcjonowania. Pellizzon wraz ze współpracownikami opisał wyniki leczenia skojarzonego w grupie ryzyka I i III, obserwując 119 chorych przez 41 miesięcy po zakończonym leczeniu [53]. Dawka całkowita wyniosła 45 Gy z EBRT i 4 frakcje po 4 Gy w niskiej oraz 4 frakcje po 5 Gy w wysokiej grupie ryzyka (HDR-BRT). Wyniki terapii oceniał pod kątem braku biochemicznych cech wznowy nowotworu (bNED - ang. biochemical no evidence of diseaese). bNED wynosiła odpowiednio dla grup I i III: 71,3\% oraz 69,5\% [53]. Hiratsuka uzyskał 93\% odsetek kontroli biochemicznej (BC - ang. biochemical control rate) w grupie 71 chorych (wszystkie grupy ryzyka) w ciagu 60 miesięcy obserwacji [54]. Pacjenci byli leczeni przy pomocy dwóch schematów: EBRT 45 lub 41,9 Gy oraz BRT-HDR 3 lub 4 x 5,5 Gy, w zależności od grupy ryzyka. 5 letnie doświadczenia samodzielnej brachyterapii HDR przedstawili autorzy z ośrodków William Beaumont Hospital (WBH) i California Endocurietherapy Center (CET) w Stanach Zjednoczonych [55]. Stosowano tzw. przyspieszone frakcjonowanie, podczas jednej aplikacji napromieniano pacjentów w ciagu 48 godzin dawką $38 \mathrm{~Gy}$, podzieloną na 4 frakcje. Po 5 latach obserwacji 248 chorych, współczynnik kontroli biochemicznej (BC) wyniósł odpowiednio dla WBH i CET 91\% i 88\%. Zaobserwowano następujące powikłania ze strony układu moczowego i pokarmowego: bolesność podczas mikcji - 39\%, wzmożoną częstotliwość oddawania moczu - 58\%, dolegliwości bólowe podczas defekacji - 6,5\%, zaburzenia seksualne $20 \%$. W tej pracy podkreślono bardzo dobre wyniki leczenia pacjentów z wczesnym nowotworem przy akceptowalnej częstotliwości występowania powikłań miejscowych. Przy prawidłowym doborze chorych do monoterapii HDR, brachyterapia HDR stanowi najbardziej konformalny sposób hipofrakcjonowania dawki z dostępnych metod radioterapii [55]. Dawkę całkowitą 38 Gy, w 4 frakcjach stosowali także Ghadjar i współpracownicy u 36 pacjentów, z grupy niskiego i pośredniego ryzyka [56]. W obserwacji 3 - letniej ustalony współczynnik bNED dla całej grupy wyniósł 100\%. Powikłania ostre i przewlekłe 3 stopnia dla cewki moczowej, 
zaobserwowano odpowiednio w 3\% i $11 \%$ i były one statystycznie skorelowane $\mathrm{z}$ parametrami planu leczenia (V120, V100, D90). Odczynów popromiennych w obrębie odbytnicy nie zanotowano [56].

Podobnie jak w innych krajach, w Polsce także nie obowiązują jednoznaczne wytyczne na temat wysokości dawek całkowitych i frakcyjnych oraz schematów ich podawania w określonych odstępach czasu. Rozbieżności pomiędzy ośrodkami radioterapeutycznymi utrudniają w znaczący sposób porównanie skuteczności leczenia raka gruczołu krokowego. W Wielkopolskim Centrum Onkologii do grudnia 2009 wykonano blisko 1000 zabiegów brachyterapii HDR u pacjentów w terapii samodzielnej lub uzupełniającej. Wyniki przedstawione po 2 latach obserwacji są zadowalające a profil toksyczności akceptowalny [57]. Pacjentów leczono w dwóch schematach skojarzonych z radioterapią wiązki zewnętrznej (EBRT/HDR-BRT) w dawce odpowiednio 50 Gy EBRT/1 frakcja HDR-BRT po 15 Gy oraz 46 Gy EBRT/2 frakcje HDR-BRT po 10 Gy. Monoterapia HDR została zaproponowana pacjentom z grupy niskiego ryzyka, o dobrym stanie ogólnym (3 frakcje po 15 Gy). Biochemiczny współczynnik kontroli miejscowej (BC) dla całej grupy wyniósł 94\%, wznowę zanotowano w 4 przypadkach (6,4\%). Stopień powikłań urologicznych i jelitowych nieznacznie odbiegał od średniej światowej. W pierwszym miesiącu dominowały odczyny typu ostrego (wzmożona częstotliwość oddawania moczu - 59\%, nietrzymanie moczu $7,9 \%$, stany zapalne układu moczowego - 22\% osłabiony strumień $68,3 \%$, krwawienie z odbytu - 15,9\%) [57]. Powyższe objawy w większości przypadków przemijały po leczeniu farmakologicznym, bez poważnych konsekwencji a ich częstotliwość występowania po 24 miesiącach obserwacji wynosiła odpowiednio: 36,51\%, 6,2\%, 1,59\%, 3,17\% [57]. Wyższy odsetek krwawień z odbytu ( $80 \%$ to chorzy z II i III grupy ryzyka) mógł, ale nie musiał wynikać z podania wyższych dawek biologicznych w leczeniu skojarzonym 50 Gy EBRT/1 frakcja HDR-BRT po $15 \mathrm{~Gy}$. W trakcie przeprowadzania brachyterapii HDR zauważono wpływ czynników prognostycznych jak objętość gruczołu oraz liczba zastosowanych aplikatorów na ostateczne wysokości dawek i objętości, uzyskane w systemie komputerowym planowania leczenia. Przeprowadzone analizy statystyczne potwierdziły fakt pogorszenia parametrów planu w miarę użycia mniejszej liczby igieł, w mniejszej objętości gruczołu [58]. Konsekwencją suboptymalnych parametrów dawek w obrębie gruczołu oraz możliwe przesunięcia punktów o wysokiej dawce w obręb narządów krytycznych, może być wyższy odsetek powikłań popromiennych. W światowym piśmiennictwie autorzy szeroko analizują wpływ wysokości dawek i objętości na wyniki leczenia pacjentów i prawdopodobieństwo wystapienia u nich poważnych powikłań po brachyterapii HDR. Nie opublikowano natomiast 
analiz statystycznych porównujących parametry dawek w obrębie gruczołu krokowego, cewki moczowej i odbytnicy w zależności od różnych schematów leczenia. Interesującym celem badań wydaje się być ocena wpływu czynników diagnostycznych na parametry planu leczenia w odmiennych schematach frakcjonowania. Stanowi to cel niniejszej pracy. 


\section{CELE PRACY}

1. Porównanie wybranych wartości dawek i parametrów objętości leczonych techniką HDR-BRT w trzech schematach frakcjonowania, z uwzględnieniem dawek biologicznych.

2. Ocena wpływu wybranych czynników prognostycznych na uzyskane wartości dawek i parametrów objętości, w zależności od różnych schematów brachyterapii HDR. 


\section{MATERIAŁ I METODYKA BADAŃ}

\subsection{Kwalifikacja do badania i kryteria wyłączenia.}

Pacjenci leczeni w Zakładzie Brachyterapii Wielkopolskiego Centrum Onkologii kwalifikowani byli do brachyterapii według kryteriów przyjętych przyjętych przez Europejskie Towarzystwo Radioterapii Onkologicznej i Europejskie Towarzystwo Urologiczne (GEC/ESTRO - EAU) [59].

Kryteria kwalifikacji do leczenia skojarzonego z EBRT były następujące:

1. Potwierdzony histopatologicznie rak gruczołu krokowego w każdym stopniu zróżnicowania komórkowego (skala GS 2-10).

2. Stopień zaawansowania klinicznego T1-T3b.

3. Każda wartość poziomu PSA (iPSA).

4. Brak przerzutów w regionalnych węzłach chłonnych oraz przerzutów odległych (TxNOM0).

5. Zgoda pacjenta na zabieg w znieczuleniu ogólnym, potwierdzona przed każdą frakcją leczenia na piśmie.

Kryteria kwalifikacji do samodzielnej brachyterapii HDR pacjentów z rakiem gruczołu krokowego w grupie niskiego ryzyka były następujące:

1. Pacjenci w stopniu zaawansowania klinicznego T1b-T2b.

2. Stopień zróżnicowania komórkowego w skali GS poniżej 6 punktów.

3. Wstępny poziom PSA poniżej $10 \mathrm{ng} / \mathrm{ml}$.

Wyodrębniono przeciwwskazania do brachyterapii HDR związane $\mathrm{z}$ techniką leczenia oraz sposobem znieczulenia w trakcie zabiegu.

Względne:

1. Rozległy zabieg TURP poprzedzający brachyterapię w czasie krótszym niż 6 miesięcy.

2. Objawy utrudnienia oddawania moczu wynikające $\mathrm{z}$ obstrukcji dróg moczowych w odcinku podpęcherzowym.

3. Kolagenowe choroby naczyniowe.

4. Spodziewane przeżycie pacjentów poniżej 5 lat.

5. Choroby psychiczne uniemożliwiające zrozumienie charakteru leczenia brachyterapią oraz wyrażenie świadomej zgody na zaproponowaną terapię. 
6. Wady anatomiczne cewki moczowej, prącia powodujące trudności w założeniu cewnika do dróg moczowych.

Bezwzględne:

1. Choroby kardiologiczne, pulmonologiczne, neurologiczne bądź laryngologiczne uniemożliwiające przeprowadzenie zabiegu w znieczuleniu ogólnym.

2. Przerzuty odległe oraz $\mathrm{w}$ obrębie regionalnego układu chłonnego udokumentowane w badaniach obrazowych.

3. Choroby powodujące usztywnienia w stawach biodrowych oraz kręgosłupa uniemożliwiające ułożenie pacjenta w pozycji litotomicznej, na plecach.

4. Objętość gruczołu krokowego powyżej $60 \mathrm{ml}$ ze względu na duże ryzyko interferencji łuku łonowego.

\subsection{Charakterystyka pacjentów.}

Badaniem objęto 65 mężczyzn $\mathrm{z}$ rozpoznaniem raka gruczołu krokowego poddanych brachyterapii HDR, w okresie od czerwca 2006 do października 2007, w Zakładzie Brachyterapii Wielkopolskiego Centrum Onkologii w Poznaniu. 55 pacjentów leczonych było w skojarzeniu z teleradioterapią (EBRT), przy czym 37 otrzymało jedną a 18 dwie frakcje brachyterapii śródtkankowej według schematu odpowiednio: EBRT 50 Gy/ + HDR-BRT 15 Gy (grupa I) i EBRT 46 Gy/+ HDR - BRT 2 x 10 Gy (grupa II). U 10 chorych zastosowano monoterapię HDR - BRT jako metodę samodzielną, stosując 3 frakcje po 15 Gy (grupa III). Średnia wieku mężczyzn w poszczególnych grupach wynosiła: grupa I - 67, grupa II - 69,5, grupa III - 69,8 lat. U większości pacjentów (n=60, 92,3\%) rozpoznano raka w stopniu T1-2. U 5 chorych miejscowo zaawansowany nowotwór gruczołu przekraczał torebkę, obejmował naciekiem pęcherzyki nasienne, bez inwazji narządów sąsiadujących (T3). Najwyższy odsetek stanowili pacjenci z niskim stopniem złośliwości histopatologicznej w skali Gleasona. Rozpoznanie w skali GS poniżej 7 punktów zaobserwowano odpowiednio, w grupach: I 45,9\%, II - 55,6\%, III - 90\%. Najwyższa, średnią wartość wstępnego PSA (iPSA) stwierdzono w grupie I - 21,96 ng/ml (zakres 6 - 96), najniższą w grupie II - 17,88 ng/ml (zakres 0,12 -50). W grupie III średnia wartości wstępnego PSA wyniosła 19,47 ng/ml (zakres 0,95-86,6 ng/ml). Powodem włączenia do grupy samodzielnej brachyterapii dwóch pacjentów z wysokim, wstępnym wynikiem PSA była wznowa po EBRT w pierwszym przypadku i brak możliwości zastosowania innego, skutecznego leczenia w drugim przypadku (endoprotezy obu stawów biodrowych). Średnia objętość gruczołu krokowego oceniana przed 
zabiegiem w TRUS okazała się najwyższa w grupie III (29,9 ml) a najniższa w grupie I (26,1 $\mathrm{ml}$ ). Najmniejsza objętość gruczołu zakwalifikowana do leczenia to $5 \mathrm{ml}$, największa $68 \mathrm{ml}$. Średnia liczba użytych do brachyterapii aplikatorów igłowych najwyższa była w grupie, z największą objętością gruczołu (grupa samodzielnej brachyterapii - 15,6, zakres 12-18 igieł). 31 mężczyzn $(47,7 \%)$ otrzymało neoadjuwantową hormonoterapię jako uzupełnienie leczenia radykalnego. Do grupy wysokiego ryzyka zaliczono 27 chorych (41,5\%), do pośredniego 9 $(13,8 \%)$, do grupy niskiego ryzyka 29 chorych (44,6\%).6 pacjentów $(9,2 \%)$ przebyło zabieg resekcji przezcewkowej (TUR-P) w okresie 6 miesięcy poprzedzającym BRT-HDR . W tabeli 4 przedstawiono szczegółową charakterystykę grup badanych.

Tabela 4. Dane pacjentów przyporządkowanych do grup wg schematów leczenia.

\begin{tabular}{|c|c|c|c|}
\hline Cechy/ grupy & $\begin{array}{c}\text { I } \\
\text { EBRT/BRT-HDR } \\
50 \text { Gy/ 1 x } 15 \text { Gy }\end{array}$ & $\begin{array}{c}\text { II } \\
\text { EBRT/BRT-HDR } \\
46 \mathrm{~Gy} / 2 \text { x } 10 \mathrm{~Gy}\end{array}$ & $\begin{array}{c}\text { III } \\
\text { BRT-HDR } \\
3 \times 15 \text { Gy }\end{array}$ \\
\hline $\begin{array}{c}\text { Wiek, mediana (zakres) } \\
\text { [lata]. } \\
\text { TNM } \\
\text { T1 } \\
\text { T2 } \\
\text { T3 } \\
\text { Skala Gleasona } \\
2-6 \text { pkt. } \\
7 \text { pkt } \\
8-10 \text { pkt. } \\
\text { iPSA } \\
\text { < } 10 \mathrm{ng} / \mathrm{ml} \\
10-20 \mathrm{ng} / \mathrm{ml} \\
>20 \mathrm{ng} / \mathrm{ml} \\
\text { Grupa ryzyka } \\
\text { Niska } \\
\text { Srednia } \\
\text { Wysoka } \\
\text { Objętość gruczołu w } \\
\text { ml, średnia, (zakres) } \\
\text { Aplikatory metalowe } \\
\text { Średnia/frakcję, } \\
\text { (zakres) } \\
\text { Hormonoterapia } \\
\text { Tak } \\
\text { Nie }\end{array}$ & $\begin{array}{c}35,1 \%(\mathrm{n}=13) \\
54,1 \%(\mathrm{n}=20) \\
10,8 \%(\mathrm{n}=4) \\
\\
45,9 \%(\mathrm{n}=17) \\
24,3 \%(\mathrm{n}=9) \\
29,7 \%(\mathrm{n}=10) \\
\\
29,7 \%(\mathrm{n}=11) \\
43,2 \%(\mathrm{n}=16) \\
27 \%(\mathrm{n}=10) \\
32,4 \%(\mathrm{n}=12) \\
18,9 \%(\mathrm{n}=7) \\
48,7 \%(\mathrm{n}=18) \\
\\
26,1(5-60) \\
13,9(7-18)\end{array}$ & $\begin{array}{c}38,9 \%(\mathrm{n}=7) \\
55,6 \%(\mathrm{n}=10) \\
5,6 \%(\mathrm{n}=1) \\
\\
55,6 \%(\mathrm{n}=10) \\
33,3 \%(\mathrm{n}=6) \\
11,1 \%(\mathrm{n}=2) \\
27,8 \%(\mathrm{n}=5) \\
33,3 \%(\mathrm{n}=6) \\
38,9 \%(\mathrm{n}=7) \\
50 \%(\mathrm{n}=9) \\
11,1 \%(\mathrm{n}=2) \\
38,9 \%(\mathrm{n}=7) \\
\\
29,1(10-66) \\
14,4(9-18)\end{array}$ & $\begin{array}{c}70 \%(\mathrm{n}=7) \\
30 \%(\mathrm{n}=3) \\
0 \\
90 \%(\mathrm{n}=9) \\
0 \\
10 \%(\mathrm{n}=1) \\
80 \%(\mathrm{n}=8) \\
0 \\
20 \%(\mathrm{n}=2) \\
80 \%(\mathrm{n}=8) \\
0 \\
20 \%(\mathrm{n}=2) \\
29,9(13-68) \\
15,6(12-18)\end{array}$ \\
\hline
\end{tabular}




\subsection{Badania wstępne, parametry diagnostyczne.}

Kwalifikacja do zabiegu brachyterapii HDR następowała po wykonaniu badań:

1. Badanie podmiotowe i przedmiotowe.

2. Badanie histopatologiczne i określony stopień zróżnicowania komórkowego (złośliwości histologicznej) określony w skali Gleasona.

3. Badanie laboratoryjne - wartość najwyższego poziomu markera swoistego antygenu sterczowego (iPSA) oraz komplet badań laboratoryjnych krwi.

4. Badanie obrazowe - transrektalna ultrasonografia - określenie stopnia zaawansowania miejscowego (cecha T w klasyfikacji TNM) oraz objętości gruczołu krokowego.

Badania dodatkowe zlecane $\mathrm{w}$ celu wykluczenia przerzutów regionalnych (cecha N) lub odległych (M) obejmowały przede wszystkim badania obrazowe takie jak zdjęcie RTG klatki piersiowej PA i boczne, tomografię komputerową miednicy mniejszej oraz scyntygrafię koścca. W wybranych przypadkach wykonywano rezonans miednicy mniejszej zwykły lub cewką endorektalną ze spektroskopia.

Badania laboratoryjne wykonywane rutynowo przed każdym zabiegiem w znieczuleniu ogólnym, miały za zadanie ocenę stanu ogólnego pacjenta, podstawowych funkcji życiowych oraz wydolności poszczególnych narządów. Należały do nich morfologia, biochemia nerkowa (kreatynina, mocznik), biochemia wątrobowa (transaminaza asparaginowa, transaminaza alaninowa), układ krzepnięcia, białko całkowite, elektrolity (sód, chlor, wapń, potas), fosfataza zasadowa, badanie ogólne moczu oraz antygen Hbs i przeciwciała anty-HCV.

$\mathrm{Na}$ podstawie powyższych badań laboratoryjnych, obrazowych oraz danych pacjentów wyodrębniono wybrane czynniki prognostyczne będące przedmiotem dodatkowej analizy statystycznej z parametrami planu leczenia. Parametry wstępne, kwalifikujące do zabiegu takie jak zaawansowanie kliniczne (TNM), wartość wyjściowa PSA oraz stopień zróżnicowania komórkowego (GS) wydawały się być wyborem oczywistym. Czynnik objętości gruczołu krokowego był parametrem obliczanym w badaniach obrazowych jako warunek przeprowadzenia zabiegu brachyterapii HDR za pomocą najłatwiej dostępnej przezodbytniczej ultrasonografii. Powyższe badanie miało ponadto wykluczyć sytuację złej lokalizacji gruczołu krokowego w stosunku do kości miednicy (interferencja łuku łonowego), uniemożliwiająca prawidłową aplikację igieł i optymalne podanie dawki promieniowania jonizującego. Liczba aplikatorów metalowych była ściśle związana z objętością gruczołu a ich wzajemne ułożenie względem siebie oraz odległość w stosunku do narządów krytycznych miało zasadnicze znaczenie w procesie planowania leczenia. Wiek chorych jako dodatkowy 
parametr wstępny nie powinien mieć znaczącego wpływu na plan leczenia i jakość deponowanej w obrębie gruczołu krokowego dawki.

\subsection{Schematy leczenia.}

Dwie pierwsze grupy pacjentów były leczone skojarzoną metodą radioterapii (EBRT/HDRBRT). Wybór chorych do tych dwóch schematów nie wynikał jednoznacznie z przynależności do grupy ryzyka wysokiego, lecz nastepował losowo. W grupie I chorzy otrzymywali metodą EBRT dawkę 50 Gy frakcjonowaną konwencjonalnie (25 frakcji po 2 Gy dziennie przez 5 tygodni leczenia), specyfikowaną na obszar gruczołu. Pole napromieniania poszerzano na układ chłonny miednicy mniejszej w przypadku zwiększonego ryzyka jego zajęcia (> 15\%), określanego na podstawie wzorów Roacha [60]. W grupie II dwie frakcje brachyterapii poprzedzała teleradioterapia konwencjonalna, w dawce całkowitej 46 Gy (23 x 2 Gy). W przypadku kwalifikacji do napromieniania węzłów chłonnych miednicy, podawano dawkę 46 Gy od wysokości promontorium do poziomu węzłów zasłonowych. Napromienianie za pomocą wiązki zewnętrznej przeprowadzano w technice trójwymiarowej, konformalnej radioterapii (3D CRT - ang. 3-dimentional conformal radiotherapy) lub modulowanej intensywności dawki (IMRT - ang. intensity modulated radiotherapy). W I i II grupie EBRT poprzedzała brachyterapię a odstęp czasowy pomiędzy tymi metodami wynosił średnio 2 tygodnie.

Samodzielna metoda brachyterapii HDR stosowana w grupie najniższego ryzyka, składała się z trzech zabiegów w znieczuleniu ogólnym, bez udziału EBRT. W Zakładzie Brachyterapii Wielkopolskiego Centrum Onkologii pacjenci otrzymywali dawkę 45 Gy w trzech frakcjach (3 x 15 Gy) z przerwami 2-tygodniowymi. Metoda śródtkankowej brachyterapii stanowiła dla tej grupy pacjentów jedyną formę postepowania terapeutycznego, co zwiększało znaczenie prawidłowej aplikacji i planowania leczenia. W tabeli 5 przedstawiono biologiczne dawki efektywne (BED) oraz dawki ekwiwalentne (EQD2) dla powyższych trzech schematów. 
Tabela 5. Porównanie efektywnych dawek biologicznych (BED) oraz dawek ekwiwalentnych (EQD2) w różnych schematach radioterapii [57].

\begin{tabular}{|c|c|c|}
\hline Schemat frakcjonowania & BED alfa/beta 1,5 & EQD2 alfa/beta 1,5 \\
\hline $\begin{array}{c}\text { EBRT/HDR-BRT 50/ } 1 \times 15 \\
\text { Gy }\end{array}$ & $281 \mathrm{~Gy}$ & $120,7 \mathrm{~Gy}$ \\
\hline $\begin{array}{r}\text { EBRT/HDR-BRT 46/2 x } \\
\text { Gy }\end{array}$ & $260 \mathrm{~Gy}$ & $111,7 \mathrm{~Gy}$ \\
\hline HDR-BRT $3 \times 15 \mathrm{~Gy}$ & $495 \mathrm{~Gy}$ & $212,1 \mathrm{~Gy}$ \\
\hline
\end{tabular}

EBRT - radioterapia przy użyciu wiązki zewnętrznej, HDR-BRT - brachyterapia z użyciem źródeł o wysokiej mocy dawki, BED - efektywna dawka biologiczna, EQD2 - dawka ekwiwalentna do 2 Gy dawki radioterapii wiązki zewnętrznej. 


\subsection{Procedura brachyterapii HDR.}

Leczenie pacjentów z rakiem gruczołu krokowego za pomocą brachyterapii HDR wymagało hospitalizacji 48 godzinnej. W dniu przyjęcia przeprowadzano wszystkie zabiegi diagnostyczne, włącznie z konsultacjami internistyczną oraz anestezjologiczną. Zastosowanie TRUS wymagało przeczyszczenia końcowego odcinka jelita grubego w dniu przyjęcia oraz wlewów doodbytniczych w dzień zabiegu. Do dróg moczowych zakładano cewniki typu Foleya lub Tiemanna celem prewencji ostrego zatrzymania moczu w dniu zabiegu oraz wizualizacji cewki w trakcie planowania leczenia. Formę znieczulenia ogólnego wybrano ze względu na komfort pacjentów i dążenie do dokładnego i sprawnego przebiegu planowania leczenia. Całkowity czas zabiegu, począwszy od wprowadzenia pacjenta do znieczulenia po usunięcie igieł i wybudzenie trwał około 90 minut. Właściwy proces leczenia chorego napromienianie śródtkankowe, w zależności od aktualnej aktywności źródła trwał krótko i wynosił od 10 do 20 minut. Specyfika zabiegu spowodowała konieczność połączenia warunków sali operacyjnej (jałowość) z pomieszczeniem ochrony radiacyjnej (leczenie w systemie następczego ładowania źródła).

$\mathrm{W}$ trakcie tej procedury terapii promieniowaniem o wysokiej mocy dawki wykorzystywano aparat terapeutyczny microSelectron ${ }^{\circledR}$ HDR (Nucletron BV, Veenendaal, The Netherlands) wraz z systemem planowania leczenia (Nucletron SWIFT ${ }^{\circledR}$ oraz Oncentra Prostate ${ }^{\circledR}$ ). Trzecim elementem koniecznym do przeprowadzenia leczenia był ultrasonograf transrektalny (ProFocus 2202 z dwupłaszczyznową głowicą 6,0 - 12,0 MHz), połączony z systemem planowania i umożliwiający planowanie brachyterapii w czasie rzeczywistym.

Za pomocą ultrasonografu uzyskane w trakcie akwizycji (odstępy co $1 \mathrm{~mm}$ ) obrazy gruczołu przekazywane były do systemu planowania tak, aby na bieżąco (ang. on-line) móc śledzić zmianę objętości celu napromieniania (ang. target) w stosunku do aplikatorów metalowych i narządów sąsiadujących. $\mathrm{Na}$ podstawie skanów transrektalnego ultrasonografu, wykorzystując algorytm odwrotnej, ślepej optymalizacji (ang. blind inverse optimization), system planowania generował parametry, związane $\mathrm{z}$ wartościami dawki w gruczole krokowym oraz narządach krytycznych (OAR).

Stabilizatorem układu TRUS - pacjent był tzw. steper (ang. stepper), czyli wyposażony w układ dźwigni mechanicznych specjalny stojak z podłużną łódką na głowicę USG u szczytu. Steper w trakcie zabiegu był sztywno unieruchamiany do podłogi, co zabezpieczało przed możliwymi rotacjami i błędami w odczycie objętości targetu przez system planowania. Główny zakres ruchu urządzenia, wykorzystywany w trakcie zabiegu to kierunki dogłowowy 
i doogonowy, góra-dół, boki prawo-lewo oraz rotacja głowicy wokół własnej osi. Wspomniane ruchy steperem wraz z obrazowaniem trójwymiarowym ultrasonografu (obraz strzałkowy, wieńcowy, poprzeczny) dawały możliwość dokładnej identyfikacji narządów w miednicy mniejszej i dobre warunki do zaplanowania brachyterapii. Ważną funkcją stepera było także utrzymywanie specjalnej płytki celowniczej (ang. template), w układzie z głowica ultrasonografu. Płytka ta posiadała siatkę układu współrzędnych skorelowaną ze swoim odpowiednikiem w systemie planowania i wyznaczała odległości pomiędzy igłami oraz prawidłowy kierunek implantacji aplikatorów igłowych.

Szczegółowy przebieg zabiegu brachyterapii HDR przedstawiono poniżej [61]:

1. W dniu zabiegu do pęcherza moczowego lekarz zakładał cewnik Foleya a balon wypełniał solą fizjologiczną celem wizualizacji ściany pęcherza i ujścia cewki moczowej. W przypadku braku możliwości założenia miękkiego cewnika zakładano sztywny cewnik Tiemanna, bez mocującego balona.

2. Po wprowadzeniu do znieczulenia ogólnego pacjenta układano w pozycji litotomicznej, $\mathrm{z}$ nogami uniesionymi oraz zrotowanymi na zewnątrz w stawach biodrowych, zgiętymi w stawach kolanowych.

3. Następnym etapem było wykonanie akwizycji obrazu gruczołu krokowego w odstępach $1 \mathrm{~mm}$, przez lekarza przeprowadzającego zabieg. Głowicę transrektalnego USG wprowadzano do odbytnicy, umocowując ją na steperze w sztywnym położeniu względem podłogi sali zabiegowej, wraz z płytką stabilizująca, ściśle przylegającą do skóry krocza pacjenta.

4. Lekarz - radioterapeuta dokonywał następnie wyznaczenia konturów poszczególnych narządów przy użyciu dostępnych narzędzi graficznych w systemie planowania leczenia. Na podstawie tych danych fizyk medyczny ustalał wstępny plan leczenia (ang. pre-planning), proponował miejsca aplikacji igieł, ich liczbę, odstępy między igłami, głębokość implantacji.

5. W warunkach pełnej aseptyki lekarz zakładał przez skórę krocza, do miąższu gruczołu krokowego czasowe implanty igłowe, od szczytu gruczołu idąc obwodowo w kierunku podstawy, według wcześniej przygotowanego planu wstępnego.

6. Ze względu na fakt zmiany objętości i położenia gruczołu krokowego, lekarz w następnym etapie dokonywał ponownej akwizycji obrazu, według zasad opisanych $\mathrm{w}$ punkcie 3. Z tych samych powodów po raz drugi obrysowywał kontury targetu oraz narządów krytycznych (OAR). 
7. Ostateczny plan leczenia (ang. live-plan) przygotowywany przez fizyka, przy użyciu odwrotnej, ślepej optymalizacji w systemie planowania leczenia, musiał uwzględniać wartości graniczne dawek w gruczole krokowym, cewce moczowej, odbytnicy (ang. dose-volume constraints, DVC). Zadaniem radioterapeuty był wybór optymalnego planu (z wielu wygenerowanych) odnosząc go do parametrów prognostycznych pacjenta (grupy ryzyka, objętość gruczołu, wieku, chorób towarzyszących pacjenta).

8. Po akceptacji planu, spełniającego wymogi DVC aplikatory igłowe podłączane były do aparatu terapeutycznego microSelectron ${ }^{\circledR}$ HDR za pomocą łączników. Zespół opuszczał salę zabiegową, będącą jednocześnie bunkrem radioprotekcyjnym, po przesłaniu planu leczenia do konsoli w sterowni HDR.

9. W trakcie procesu napromieniania pacjent pozostawał pod ciagłym nadzorem wizualnym, dźwiękowym zespołu terapeutycznego $\mathrm{z}$ monitorowaniem funkcji życiowych. Dawka promieniowania jonizującego w brachyterapii HDR pochodziła $\mathrm{z}$ rozpadu żródła irydowego Ir-192, wprowadzanego po kolei do każdej z igieł i zatrzymywanego w określonym miejscu na określony w planie leczenia czas.

10. Po zakończeniu brachyterapii źródło automatycznie wycofywano do sejfu ochronnego. Lekarz - radioterapeuta dokonywał usunięcia igieł z miąższu gruczołu, zakładał opatrunek uciskowy, tamując ewentualne krwawienie z krocza. Końcowym etapem było wybudzenie pacjenta $\mathrm{i}$ przewiezienie go na salę chorych $\mathrm{z}$ ciagłym nadzorem funkcji oddechowych i krążeniowych chorego.

\subsection{Parametry dawek i objętości planu leczenia.}

Parametry generowane podczas procedury planowania leczenia $\mathrm{w}$ brachyterapii HDR, określają wysokości dawek podanych w konkretnej objętości gruczołu krokowego i wybranych narządach krytycznych. Niezależnie od schematu leczenia celem radioterapeuty i współpracującego z nim fizyka jest podanie dawek promieniowania jonizującego specyfikowanych na torebkę gruczołu, z marginesem (cecha T3) lub bez. Z założenia więc, dawka podana powinna być maksymalnie jednorodna i obejmować izodozą 100\% cały organ, bez obecności miejsc niedopromienionych (ang. cold spots - tzw. punkty zimne). Z istoty promieniowania, pochodzącego z rozpadu promieniotwórczego oraz faktu umieszczenia źródła wewnątrz guza nowotworowego wynika fakt niskiej homogenności dawki możliwej do 
otrzymania podczas leczenia brachyterapią HDR. W systemie planowania leczenia na konturze gruczołu wyraźnie widać miejsca punktowe, wielokrotnie przekraczające założenia planu pierwotnego (ang. hot spots - tzw. punkty gorące). Niedopromienienie celu brachyterapii (szczególnie miejsca podejrzanego o rozrost nowotworowy) może spowodować niewyleczenie pacjenta, $\mathrm{z}$ drugiej strony punkty dawek wysokich to zagrożenie powikłaniami w obrębie gruczołu i okolicznych narządów.

System planowania leczenia w brachyterapii HDR raka gruczołu krokowego po wprowadzeniu wstępnych danych (dawki referencyjne, oraz ograniczające - ang. dose-volume constraints, DVC) generuje szereg planów z różnorodnymi wartościami objętości określonej izodozy oraz dawki przy określonej objętości narządów. Zadaniem lekarza przeprowadzającego zabieg jest taki wybór planu, aby w grupie wysokiego ryzyka izodoza dawki punktowo wyższej zogniskowana była w rejonie płata obwodowego lub widocznego nacieku, przy możliwym oszczędzeniu cewki moczowej i odbytnicy. Podobnie w grupie ryzyka niskiego lub w sytuacji gdzie guz nie jest widoczny (T1), plan powinien być jednorodny, dawki punktów gorących homogenne, bardziej zbliżone do wartości 100\%, specyfikowane bez marginesu, dokładnie na torebkę narządu. Parametry dawki i objętości dotyczące gruczołu krokowego, określają normy i dokładność podania pożądanej dawki. W obrębie narządów krytycznych informują o dopuszczalnym ryzyku powikłań leczenia przy akceptacji parametrów uzyskanych dla targetu.

Ze względu na warunki anatomiczne jako narządy ryzyka wybrano cewkę moczową (przebiega przez środek napromienianego gruczołu krokowego) oraz przednią ścianę odbytnicy (styczność z płatem obwodowym i najczęstszym siedliskiem nowotworów). Nie zdecydowano się na włączenie do OAR ściany pęcherza moczowego ze względu na deponowanie w jej obrębie relatywnie niskiej dawki, wynikającej z faktu zatrzymania źródła w I pozycji w odległości $1 \mathrm{~cm}$ od końca aplikatora igłowego. Nie włączono do badań parametrów z opuszki prącia czy pęczków naczyniowo-nerwowych (zlokalizowane u podstawy i bocznie od gruczołu).

W obszarze gruczołu krokowego wyróżniono następujące parametry objętości i dawki (tabela $6)$ :

- $\mathrm{D}_{\min }(\%), \mathrm{BED}_{\min }$ (Gy) (ang. biologic effective, minimal dose, dawka biologiczna minimalna),

- $\mathrm{D}_{\max }(\%), \mathrm{BED}_{\max }$ (Gy) (ang. biologic effective, maximal dose, dawka biologiczna maksymalna), 
- $\mathrm{D}_{\text {mean }}(\%), \mathrm{BED}_{\text {mean }}$ (Gy) (ang. biologic effective, mean dose, dawka biologiczna średnia),

- $\mathrm{D}_{90}(\%), \mathrm{BED}_{90}(\mathrm{~Gy})$ (wartość dawki referencyjnej dostarczonej na $90 \%$ leczonej objętości),

- $\mathrm{V}_{100} \mathrm{~V}_{120}, \mathrm{~V}_{150}, \mathrm{~V}_{200}(\%)$ (wartość objętości otrzymującej odpowiednio $100 \%$, $120 \%, 150 \%$ i $200 \%$ dawki referencyjnej),

- $\operatorname{SD}(\%)$ (odchylenie standardowe).

W obszarze narządów ryzyka (cewka moczowa i przednia ściana odbytnicy) odpowiednio:

- $\mathrm{D}_{\min }(\%), \mathrm{BED}_{\min }(\mathrm{Gy})$,

- $\mathrm{D}_{\max }(\%), \mathrm{BED}_{\max }(\mathrm{Gy})$,

- $\mathrm{D}_{\text {mean }}(\%), \mathrm{BED}_{\text {mean }}(\mathrm{Gy})$,

- $\mathrm{D}_{10}(\%), \mathrm{BED}_{10}(\mathrm{~Gy})$, (wartość dawki referencyjnej dostarczonej do $10 \%$ objętości narządu krytycznego w trakcie leczenia),

- $\mathrm{V}_{100}(\%)$, (wartość objętości otrzymującej 100\% dawki referencyjnej),

- $\mathrm{V}_{\text {crit. }}(\%)$ (objętość narządu krytycznego otrzymująca dawkę wyższą od ograniczającej DVC; wyrażona w procentach objętości całkowitej targetu),

- $\mathrm{SD}(\%)$.

Niezależnie od grup ryzyka, wśród parametrów przyjęto wartości dawek ograniczających (DVC) dla narządów, stanowiących kryteria akceptacji planu leczenia. Wśród parametrów dawki dla gruczołu krokowego najważniejszym był $\mathrm{D}_{90}$. Wartość określająca, jaka wielkość dawki założonej została zdeponowana w 90\% objętości targetu, podawana w procentach powinna wynosić $\geq 90 \%$. Parametr objętości $V_{200}$ (informacja o objętości punktów dawki $200 \%$ - tzw. punktów gorących) nie mógł przekroczyć 15\% powierzchni gruczołu krokowego. Dawka maksymalna obserwowana punktowo w obrębie targetu to wartość możliwie najniższa w stosunku do dawki referencyjnej. Celem prewencji powikłań późnych w okolicy cewki moczowej (zwężenia popromienne) ustalono granice procentowego parametru dawki $\mathrm{D}_{10}$ na $<130 \%$ i dawki maksymalnej $<160 \%$ jako warunek akceptacji planu. Podobnie dla odbytnicy parametr $\mathrm{D}_{10}$ powinien być utrzymywany poniżej $65 \%$, natomiast dawka maksymalna poniżej $85 \%$. W tabeli 7 zebrano dawki ograniczające dla gruczołu krokowego i narządów ryzyka. 
Tabela 6. Parametry dawek i objętości dla gruczołu krokowego, cewki moczowej, odbytnicy wykorzystane w korelacjach statystycznych.

\begin{tabular}{|c|c|c|c|}
\hline Dawka/objętość & & metry optymalizac & ne \\
\hline \multirow{8}{*}{ Parametry dawki } & Prostata & Cewka moczowa & Odbytnica \\
\hline & $\mathrm{D}_{\min -\mathrm{p}}$ & $\mathrm{D}_{\min -\mathrm{u}}$ & $D_{\min -r}$ \\
\hline & $\mathrm{BED}_{\min -\mathrm{p}}$ & $\mathrm{BED}_{\min -\mathrm{u}}$ & $\mathrm{BED}_{\min -\mathrm{r}}$ \\
\hline & $\mathrm{D}_{\max -\mathrm{p}}$ & $D_{\max -u}$ & $D_{\max -r}$ \\
\hline & $\mathrm{BED}_{\max -\mathrm{p}}$ & $\mathrm{BED}_{\max -\mathrm{u}}$ & $\mathrm{BED}_{\max -\mathrm{r}}$ \\
\hline & $\mathrm{D}_{\text {mean -p }}$ & $\mathrm{D}_{\text {mean - } \mathrm{u}}$ & $\mathrm{D}_{\text {mean - } \mathrm{r}}$ \\
\hline & $\mathrm{BED}_{\text {mean -p }}$ & $\mathrm{BED}_{\text {mean - u }}$ & $\mathrm{BED}_{\text {mean - } \mathrm{r}}$ \\
\hline & SD - p & $\mathrm{SD}-\mathrm{u}$ & $S D-r$ \\
\hline \multirow{6}{*}{ Parametry objętości } & $\mathrm{D}_{90-\mathrm{p}}$ & $\mathrm{D}_{10-\mathrm{u}}$ & $\mathrm{D}_{10-\mathrm{r}}$ \\
\hline & $\mathrm{BED}_{90-\mathrm{p}}$ & $\mathrm{BED}_{10-\mathrm{u}}$ & $\mathrm{BED}_{10 \text { - r }}$ \\
\hline & $\mathrm{V}_{100-\mathrm{p}}$ & $\mathrm{V}_{\text {crit.- u }}$ & $\mathrm{V}_{\text {crit. - r }}$ \\
\hline & $\mathrm{V}_{120-\mathrm{p}}$ & $\mathrm{V}_{100-\mathrm{u}}$ & $\mathrm{V}_{100-\mathrm{r}}$ \\
\hline & & $\mathrm{V}_{150-\mathrm{p}}$ & \\
\hline & & $V_{200-p}$ & \\
\hline
\end{tabular}

Tabela 7. Dawki akceptacji planu leczenia (DVC) dla poszczególnych narządów [58].

\begin{tabular}{|c|c|c|}
\hline Gruczołu krokowego & Cewka moczowa & Odbytnica \\
\hline $\mathbf{D}_{\mathbf{9 0 - p}}>90 \%$ & $\mathbf{D}_{\mathbf{1 0 - \mathbf { u }}}<130 \%$ & $\mathbf{D}_{\mathbf{1 0 - r}}<65 \%$ \\
\hline $\mathbf{V}_{\mathbf{2 0 0 - p}}<15 \%$ & $\mathbf{D}_{\text {max-u }}<160 \%$ & $\mathbf{D}$ max-r $<85 \%$ \\
\hline $\begin{array}{c}\mathbf{D}_{\text {max-p }} \text { możliwie } \\
\text { najniższe }\end{array}$ & & \\
\hline
\end{tabular}


Na potrzeby pracy wysokość efektywnych dawek biologicznych (BED), obliczona została ze wzoru na podstawie procentowych parametrów optymalizacyjnych planu leczenia [62]:

$\mathrm{BED}=\mathrm{nd} \mathrm{x}[1+\mathrm{d} / \alpha / \beta]$

gdzie: $n$ - liczba frakcji, d - dawka frakcyjna, współczynnik $\alpha / \beta$ - zdolność naprawcza komórek.

Wartość BED wyznaczono aby w pełni przedstawić skutki działania napromieniania zewnętrznego i wewnętrznego narządów poddanych radioterapii w leczeniu raka gruczołu krokowego. Dawka efektywna jest podstawową wielkością stosowaną do oceny ryzyka powikłań przy napromienianiu narządów i tkanek, w przepisach prawnych limitująca narażenie na promieniowanie. Pomocniczo, w celu porównania dawek podawanych z teleradioterapii oraz brachyterapii HDR obliczono ponadto dawki tzw. izoefektywne (EQD2) ze wzoru [62]:

$\mathrm{EQD} 2=\mathrm{BED} /[1+2(\alpha / \beta)]$

gdzie: BED - dawka efektywna biologiczne, współczynnik $\alpha / \beta$ - zdolność naprawcza komórek.

Współczynnik $\alpha / \beta$ dla obliczeń biologicznych dawek efektywnych, deponowanych w obrębie gruczołu krokowego przyjęto za Brennerem jako 1,5, uznając tą wartość za najbardziej zbliżoną prawdzie, w badaniach na modelach radiobiologicznych [37].

\subsection{Analiza statystyczna pracy.}

Obliczenia statystyczne przeprowadzono przy użyciu programu Statistica 8.0. Podstawowym zadaniem niniejszej pracy jest porównanie średnich wartości dawek i objętości, generowanych $\mathrm{w}$ trakcie procedury planowania leczenia przez system $\mathrm{w}$ trzech różnych schematach napromieniania, $\mathrm{z}$ uwzględnieniem dawek biologicznych. Parametry objętościowe wyrażone są w procentach natomiast parametry dawki w procentach i grejach. $\mathrm{Na}$ podstawie testów statystycznych oceniono ponadto mechanizmy zmienności dawek biologicznych, w schematach o większej liczbie frakcji, ze szczególnym uwzględnieniem możliwości pogorszenia tych parametrów w obrębie narządów krytycznych. Przedstawiono wpływ wysokości dawki frakcyjnej na wartości parametrów planu leczenia, poprzez ich porównanie $w$ trzech odmiennych grupach. Dodatkowo zbadano korelację statystyczną pomiędzy wybranymi czynnikami prognostycznymi oraz parametrami dla gruczołu krokowego, cewki moczowej i odbytnicy w celu oceny czynników ryzyka eskalacji dawki dla tych narządów, w trakcie zabiegu brachyterapii. 
Parametry dawki i objętości w poszczególnych grupach o różnym frakcjonowaniu skorelowano ze sobą tak, aby możliwe było porównanie średnich parametrów uzyskanych w trakcie procesu leczenia. Wszystkie wartości liczbowe sprawdzono testem Shapiro - Wilka pod kątem cech rozkładu normalnego, opracowano statystykę opisową. Zaproponowano wykonanie analizy pomiędzy parametrami pierwszej frakcji (w tej grupie tylko jedna frakcja leczenia) oraz średnimi wartościami z odpowiednio dwóch i trzech frakcji w grupie II i III. Wartości procentowe dawek i objętości porównano we wszystkich trzech grupach leczenia za pomocą testu Kruskala - Wallisa (test K-W) dla zmiennych niezależnych. Porównanie wartości dawek biologicznych przedstawionych w grejach było możliwe tylko w grupach I i III (identyczna, średnia dawka frakcyjna - 15 Gy). W tym przypadku zastosowano test Manna - Whitneya dla porównań dwustronnych, zmiennych niezależnych. W przypadku istotności statystycznej dla potwierdzenia różnic pomiędzy poszczególnymi parametrami (I i II, II i III, I i III) zastosowano test Dunn'a. Analiza statystyczna parametrów została wykonana ponadto, pomiędzy frakcjami w II i III grupie pacjentów poddanych brachyterapii HDR. Porównania zmiennych zależnych pomiędzy dwoma frakcjami dokonano $\mathrm{w}$ teście kolejności par Wilcoxona, pomiędzy trzema frakcjami w teście Friedmanna. Korelację statystyczną pomiędzy czynnikami prognostycznymi a wartościami dawek i objętości wykonano za pomocą testu porządku rang Spearmanna. Schemat zastosowanych testów statystycznych został przedstawiony na rycinie 1 .

W ocenie możliwych zależności, przy użyciu powyższych testów, za korelację dodatnią uznano wartości z poziomem istotności statystycznej (p-value) $<0,05$. Wartości p nieznacznie powyżej 0,05, wypunktowano jako znaczące, ale nieistotne statystycznie. 
Rycina 1. Sposoby analizy statystycznej pomiędzy schematami leczenia.

TNM - klasyfikacja zaawansowania klinicznego, GS - skala Gleasona, i-PSA - najwyższe wstępna wartość PSA, EBRT - radioterapia wiązki zewnętrznej, HDR-BRT - brachyterapia HDR.

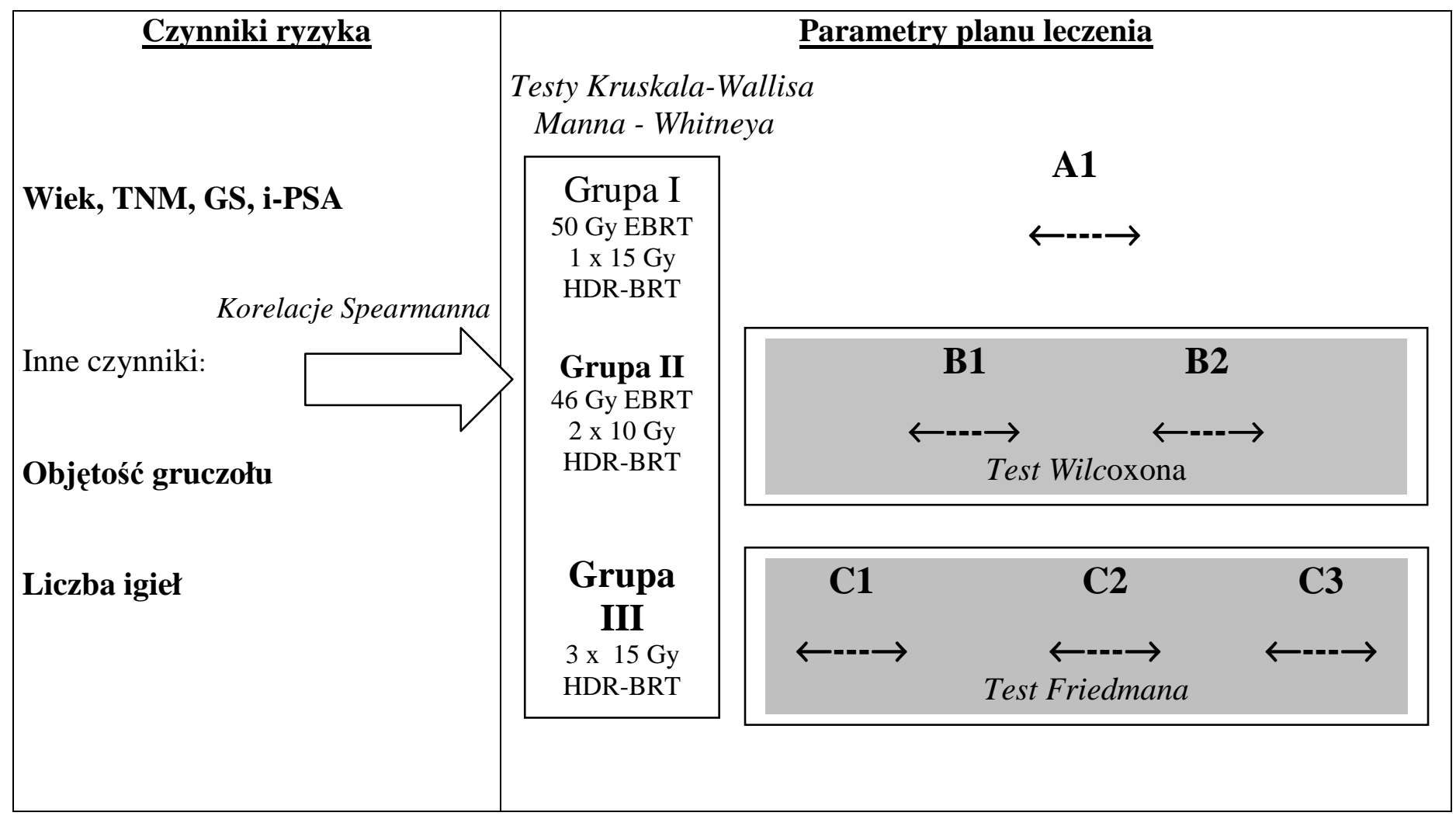

1. A1 - I frakcja w grupie I

2. B1 v B2 $-1,2$ frakcja $w$ grupie II

3. $\mathrm{C} 1 \vee \mathrm{C} 3$ v C3 $-1,2,3$ frakcja $\mathrm{w}$ grupie III 


\section{WYNIKI.}

\subsection{Wartości dawek i objętości w gruczole krokowym i narządach krytycznych.}

W analizowanym materiale najwyższą wartość parametru $D_{90-p}$ w obrębie gruczołu krokowego zaobserwowano w grupie III (mediana 94,3\%, BED=155,3 Gy) oraz w grupie I (92,1\%, 151,1 Gy). Najniższe wartości $\mathrm{D}_{90-p}$ notowane były w grupie II - najniższa wartość biologicznej dawki efektywnej dla pojedyńczej frakcji 10 Gy (mediana 87,8\%, BED=67,3 Gy). Obliczona mediana $\mathrm{D}_{90-p}$ licząc dla pojedyńczej frakcji, dla ogółu chorych wyniosła 91,4\%, w BED 124,8 Gy. Mediany dawek maksymalnych ( BED $\left._{\max -\mathrm{p}}\right)$, podane pacjentom na obszar gruczołu, w trakcie procedury leczenia wynosiły odpowiednio dla grup od I do III: 1759,6 Gy, 1390 Gy oraz 1779 Gy. Biologiczna dawka średnia (BED mean-p $_{\text {- }}$ dla wszystkich grup chorych była równa 209,1 Gy. Najwyższy parametr $\mathrm{V}_{200-p}$, informujący o punktach wysokiej dawki (ang. overdose) zaobserwowano w grupie II (średnio 15,9\%), najniższy w grupie I $(13,5 \%)$, uśredniając wartość dla pojedyńczej frakcji leczenia.

Wartość dawki podanej na $10 \%$ objętości cewki moczowej jako narządu ryzyka $\left(\mathrm{BED}_{10-\mathrm{u}}\right)$ kształtowała się średnio od 53,5 Gy w grupie II do 109,9 Gy w I, na jedną frakcję. Mediana wartości $\mathrm{BED}_{\text {mean-u }}$ dla ogółu wyniosła $67 \mathrm{~Gy}$, najwyższa wartość biologicznych dawek maksymalnych i najniższa minimalnych wyniosła odpowiednio: 130,8 Gy (grupa III) oraz 18,5 Gy (grupa II). Dla poszczególnych grup leczenia zaobserwowana objętość cewki moczowej, która otrzymała $100 \%$ wartości dawki wyjściowej $\left(\mathrm{V}_{100-\mathrm{u}}\right)$ kształtowała się odpowiednio: 46,1, 54,2 oraz 49,3\%.

Wartość $\mathrm{V}_{100-u}$ dla drugiego narządu ryzyka - odbytnicy, obliczony dla wszystkich chorych ustalono średnio na 46,9 Gy, ponownie uwzględniając niższą dawkę frakcyjną w przypadku schematu EBRT 46 Gy/BRT 2 x 10 Gy. Dawka biologiczna BED mean-r w przypadku odbytnicy najniższa okazała się w przypadku II grupy (20,1 Gy), wyższa w grupach I i III odpowiednio: 39,6, 43 Gy. Wartość średnią parametru objętościowego $\mathrm{V}_{100-\mathrm{r}}(\%)$ okazała się najwyższa dla grupy I $(0,43)$ i wyraźnie niższa była w przypadku grupy monoterapii $(0,18)$.

Efektywne dawki biologiczne (BED) dla prostaty zostały obliczone dla współczynnika $\alpha / \beta$ równego 1,5 (dawka na guz), natomiast dla organów ryzyka dla $\alpha / \beta 3$ (dawka dla późnych odczynów popromiennych). Wartości parametrów prognostycznych w trzech schematach leczenia przedstawiono w tabeli 8. Pozostałe wartości liczbowe statystyki opisowej pracy przedstawiono w tabeli 9,10 i 11 . 
Tabela 8. Statystyka opisowa parametrów prognostycznych dla gruczołu krokowego w trzech grupach.

\begin{tabular}{|c|c|c|c|c|c|c|c|}
\hline Parametr/Grupy & Jedn. & Maks. & Min. & Średnia & Mediana & SD & $\begin{array}{l}\text { Liczba } \\
\text { frakcji }\end{array}$ \\
\hline $\begin{array}{r}\text { I } \\
\text { II } \\
\text { III }\end{array}$ & lata & $\begin{array}{l}77 \\
77 \\
89\end{array}$ & $\begin{array}{l}53 \\
56 \\
59\end{array}$ & $\begin{array}{c}67 \\
69,5 \\
69,8\end{array}$ & $\begin{array}{c}67 \\
71,5 \\
69\end{array}$ & $\begin{array}{l}6,48 \\
6,23 \\
8,22\end{array}$ & $\begin{array}{l}37 \\
36 \\
30\end{array}$ \\
\hline $\begin{array}{r}\text { I } \\
\text { II } \\
\text { III }\end{array}$ & $\mathrm{ng} / \mathrm{ml}$ & $\begin{array}{c}96 \\
50 \\
86,6\end{array}$ & $\begin{array}{c}6 \\
0,12 \\
0,95\end{array}$ & $\begin{array}{l}21,96 \\
17,88 \\
19,47\end{array}$ & $\begin{array}{c}13,2 \\
10,57 \\
9,1\end{array}$ & $\begin{array}{l}22,24 \\
14,83 \\
25,55\end{array}$ & $\begin{array}{l}37 \\
36 \\
30\end{array}$ \\
\hline $\begin{array}{cc} & \text { I } \\
\text { Gleason score } & \text { II } \\
\text { III }\end{array}$ & liczba & $\begin{array}{c}10 \\
9 \\
8\end{array}$ & $\begin{array}{l}3 \\
2 \\
4\end{array}$ & $\begin{array}{c}6,66 \\
5,47 \\
5,5\end{array}$ & $\begin{array}{l}7 \\
6 \\
5\end{array}$ & $\begin{array}{l}1,37 \\
1,94 \\
1,51\end{array}$ & $\begin{array}{l}37 \\
36 \\
30\end{array}$ \\
\hline $\begin{array}{r}\text { I } \\
\text { II } \\
\text { III }\end{array}$ & $\mathrm{ml}$ & $\begin{array}{l}60 \\
66 \\
68\end{array}$ & $\begin{array}{c}5 \\
10 \\
13\end{array}$ & $\begin{array}{c}26,1 \\
29,06 \\
29,9\end{array}$ & $\begin{array}{l}25 \\
26 \\
30\end{array}$ & $\begin{array}{l}11,1 \\
15,2 \\
16,5\end{array}$ & $\begin{array}{l}37 \\
36 \\
30\end{array}$ \\
\hline $\begin{array}{lr} & \text { I } \\
\text { Aplikatory } & \text { II } \\
& \text { III }\end{array}$ & liczba & $\begin{array}{l}18 \\
18 \\
18\end{array}$ & $\begin{array}{c}7 \\
9 \\
12\end{array}$ & $\begin{array}{c}13,9 \\
14,38 \\
15,6\end{array}$ & $\begin{array}{c}13 \\
14 \\
15,5\end{array}$ & $\begin{array}{l}2,29 \\
2,79 \\
2,17\end{array}$ & $\begin{array}{l}37 \\
36 \\
30\end{array}$ \\
\hline
\end{tabular}


Tabela 9. Statystyka opisowa parametrów dawek i objętości dla gruczołu krokowego $(\alpha / \beta=1,5)$ w trzech grupach wg schematów leczenia.

\begin{tabular}{|c|c|c|c|c|c|c|c|c|}
\hline Parametr & $\begin{array}{c}\text { Grupy } \\
\text { leczenia }\end{array}$ & Jednostki & Maks. & Min. & Średnia & Mediana & SD & $\begin{array}{l}\text { Liczba } \\
\text { frakcji }\end{array}$ \\
\hline \multirow{3}{*}{$D_{90-p}$} & $\mathrm{I}$ & \multirow{3}{*}{$\%$} & 98,54 & 66,9 & 90,86 & 92,05 & 6,19 & 37 \\
\hline & II & & 98,31 & 76,59 & 88,23 & 87,76 & 6,74 & 36 \\
\hline & III & & 95,78 & 81,72 & 92,03 & 94,31 & 4,72 & 30 \\
\hline \multirow{3}{*}{$\mathrm{BED}_{90-\mathrm{p}}$} & I & \multirow{3}{*}{ Gy } & 162,59 & 110,39 & 149,92 & 151,88 & 10,21 & 37 \\
\hline & II & & 75,4 & 58,74 & 67,7 & 67,31 & 5,12 & 36 \\
\hline & III & & 158,03 & 134,83 & 151,92 & 155,31 & 7,73 & 30 \\
\hline \multirow{3}{*}{$D_{\text {max }-p}$} & I & \multirow{3}{*}{$\%$} & 2261,81 & 534,75 & 1192,46 & 1066,46 & 462,37 & 37 \\
\hline & II & & 3511,83 & 622,06 & 1906,19 & 1812,24 & 749,15 & 36 \\
\hline & III & & 2036,36 & 744,51 & 1182,16 & 1078,17 & 425,08 & 30 \\
\hline \multirow{3}{*}{$\mathrm{BED}_{\text {max-p }}$} & I & \multirow{3}{*}{ Gy } & 3731,99 & 882,34 & 1967,56 & 1759,56 & 762,91 & 37 \\
\hline & II & & 2693,57 & 477,12 & 1460,64 & 1389,99 & 574,38 & 36 \\
\hline & III & & 3360 & 1228,64 & 1950,57 & 1778,98 & 701,38 & 30 \\
\hline \multirow{3}{*}{$\mathrm{D}_{\text {min-p }}$} & I & \multirow{3}{*}{$\%$} & 64,94 & 42,83 & 56,24 & 55,76 & 5,76 & 37 \\
\hline & II & & 63,41 & 43,08 & 55,44 & 55,09 & 5,49 & 36 \\
\hline & III & & 61,89 & 50,65 & 56,97 & 58,05 & 4,19 & 30 \\
\hline \multirow{3}{*}{$\mathrm{BED}_{\text {min-p }}$} & I & \multirow{3}{*}{ Gy } & 107,2 & 70,67 & 92,8 & 92 & 9,5 & 37 \\
\hline & II & & 48,6 & 33,04 & 42,33 & 42,25 & 4,61 & 36 \\
\hline & III & & 102,1 & 83,57 & 94 & 95,78 & 6,91 & 30 \\
\hline \multirow{3}{*}{$\mathrm{D}_{\text {mean-p }}$} & I & \multirow{3}{*}{$\%$} & 197,77 & 139,1 & 155,13 & 152,81 & 11,04 & 37 \\
\hline & II & & 176,48 & 149,44 & 157,95 & 155,15 & 7,7 & 36 \\
\hline & III & & 164,99 & 143,66 & 154,90 & 155,23 & 6,99 & 30 \\
\hline \multirow{3}{*}{$\mathrm{BED}_{\text {mean-p }}$} & I & \multirow{3}{*}{ Gy } & 326,32 & 229,52 & 255,97 & 252,14 & 18,22 & 37 \\
\hline & II & & 135,36 & 114,62 & 121,21 & 119 & 5,9 & 36 \\
\hline & III & & 272,59 & 237,03 & 255,88 & 256,13 & 11,74 & 30 \\
\hline \multirow{3}{*}{$\mathrm{SD}_{-\mathrm{p}}$} & I & \multirow{3}{*}{$\%$} & 141,01 & 23,06 & 71,2 & 68,05 & 24,22 & 37 \\
\hline & II & & 149,83 & 50,54 & 95,4 & 93,28 & 27,9 & 36 \\
\hline & III & & 85,47 & 58,81 & 75,18 & 75,94 & 8,05 & 30 \\
\hline \multirow{3}{*}{$\mathrm{V}_{100-\mathrm{p}}$} & I & \multirow{3}{*}{$\%$} & 89,19 & 69,09 & 85,01 & 85,33 & 3,59 & 37 \\
\hline & II & & 88,95 & 74,13 & 82,69 & 82,5 & 4,35 & 36 \\
\hline & III & & 87,31 & 79 & 85,06 & 86,63 & 3 & 30 \\
\hline \multirow{3}{*}{$\mathrm{V}_{120-\mathrm{p}}$} & I & \multirow{3}{*}{$\%$} & 74,15 & 60,88 & 69,47 & 70,46 & 3,54 & 37 \\
\hline & II & & 73,92 & 58,92 & 66,61 & 67,62 & 4,43 & 36 \\
\hline & III & & 72,97 & 62,49 & 67,53 & 68,71 & 3,55 & 30 \\
\hline \multirow{3}{*}{$\mathrm{V}_{150-\mathrm{p}}$} & I & \multirow{3}{*}{$\%$} & 53,07 & 29,25 & 41,48 & 41,15 & 6,5 & 37 \\
\hline & II & & 49,09 & 33,34 & 40,09 & 39,35 & 4,26 & 36 \\
\hline & III & & 50,89 & 29,3 & 39,3 & 39,17 & 6,03 & 30 \\
\hline \multirow{3}{*}{$\mathrm{V}_{200-\mathrm{p}}$} & I & & 33,22 & 7,29 & 15,22 & 13,5 & 6,1 & 37 \\
\hline & II & $\%$ & 23,97 & 10,09 & 16,31 & 15,93 & 3,48 & 36 \\
\hline & III & & 22,82 & 9,5 & 14,97 & 14,71 & 4,23 & 30 \\
\hline
\end{tabular}


Tabela 10. Statystyka opisowa parametrów dawek i objętości dla cewki moczowej $(\alpha / \beta=3)$ w trzech grupach wg schematów leczenia.

\begin{tabular}{|c|c|c|c|c|c|c|c|c|}
\hline Parametr & $\begin{array}{c}\text { Grupy } \\
\text { leczenia }\end{array}$ & Jednostki & Maks. & Min. & Średnia & Mediana & SD & $\begin{array}{l}\text { Liczba } \\
\text { frakcji }\end{array}$ \\
\hline \multirow{3}{*}{$D_{10-u}$} & $\mathrm{I}$ & \multirow{3}{*}{$\%$} & 152,91 & 78,78 & 122,32 & 122,09 & 11,74 & 37 \\
\hline & II & & 131,86 & 112,88 & 124,09 & 123,48 & 5,36 & 36 \\
\hline & III & & 126,61 & 109,92 & 120,37 & 121,28 & 5,01 & 30 \\
\hline \multirow{3}{*}{$\mathrm{BED}_{10-\mathrm{u}}$} & I & \multirow{3}{*}{ Gy } & 137,62 & 70,9 & 110,09 & 109,88 & 10,56 & 37 \\
\hline & II & & 57,09 & 48,88 & 53,73 & 53,47 & 2,32 & 36 \\
\hline & III & & 113,94 & 98,92 & 108,33 & 109,15 & 4,51 & 30 \\
\hline \multirow{3}{*}{$D_{\max -u}$} & I & \multirow{3}{*}{$\%$} & 220,89 & 97,08 & 143,18 & 137,94 & 21,14 & 37 \\
\hline & II & & 178,39 & 120,69 & 144,7 & 144,38 & 14,21 & 36 \\
\hline & III & & 149,13 & 127,37 & 140,79 & 145,18 & 8,18 & 30 \\
\hline \multirow{3}{*}{$\mathrm{BED}_{\text {max }-\mathrm{u}}$} & I & \multirow{3}{*}{ Gy } & 198,8 & 87,37 & 128,86 & 124,15 & 19,03 & 37 \\
\hline & II & & 77,24 & 52,26 & 62,47 & 62,3 & 6,37 & 36 \\
\hline & & & 134,22 & 114,64 & 126,74 & 130,78 & 7,38 & 30 \\
\hline \multirow{3}{*}{$\mathrm{D}_{\text {min-u }}$} & I & \multirow{3}{*}{$\%$} & 47,43 & 18,1 & 33,28 & 32,41 & 8,09 & 37 \\
\hline & II & & 56,31 & 23,97 & 42,2 & 42,72 & 8,57 & 36 \\
\hline & III & & 44,61 & 19,28 & 36,64 & 40 & 7,19 & 30 \\
\hline \multirow{3}{*}{$\mathrm{BED}_{\text {min-u }}$} & I & \multirow{3}{*}{ Gy } & 42,69 & 16,29 & 29,95 & 29,17 & 7,28 & 37 \\
\hline & II & & 24,38 & 10,38 & 18,27 & 18,5 & 3,71 & 36 \\
\hline & III & & 40,15 & 17,19 & 32,96 & 36 & 6,51 & 30 \\
\hline \multirow{3}{*}{$\mathrm{D}_{\text {mean-u }}$} & I & \multirow{3}{*}{$\%$} & 108,11 & 69,39 & 90,23 & 89,34 & 8,88 & 37 \\
\hline & II & & 107,4 & 79,02 & 97,34 & 97,69 & 6,73 & 36 \\
\hline & III & & 101,11 & 66,63 & 86,79 & 86,96 & 10,77 & 30 \\
\hline \multirow{3}{*}{$\mathrm{BED}_{\text {mean-u }}$} & I & \multirow{3}{*}{ Gy } & 97,3 & 62,45 & 81,21 & 80,41 & 7,99 & 37 \\
\hline & II & & 46,51 & 34,22 & 42,15 & 42,3 & 2,91 & 36 \\
\hline & III & & 91 & 59,97 & 78,12 & 78,27 & 9,69 & 30 \\
\hline \multirow{3}{*}{$\mathrm{SD}_{-\mathrm{u}}$} & I & \multirow{3}{*}{$\%$} & 44,95 & 20,63 & 28,36 & 27,27 & 5,47 & 37 \\
\hline & II & & 28,94 & 18,66 & 24,02 & 24,26 & 2,99 & 36 \\
\hline & III & & 31,74 & 20,84 & 27,1 & 26,8 & 3,69 & 30 \\
\hline \multirow{3}{*}{$\mathrm{V}_{100-\mathrm{u}}$} & I & \multirow{3}{*}{$\%$} & 71,36 & 20,37 & 46 & 46,12 & 12,42 & 37 \\
\hline & II & & 67,67 & 25,63 & 53,76 & 54,20 & 9,51 & 36 \\
\hline & III & & 62,92 & 17,35 & 46,57 & 49,33 & 12,94 & 30 \\
\hline \multirow{3}{*}{$\mathrm{V}_{\text {crit-r }}$} & I & \multirow{3}{*}{$\%$} & 52,91 & 0 & 17,08 & 12,78 & 13,98 & 37 \\
\hline & II & & 31,9 & 0,04 & 19,43 & 20,19 & 9,04 & 36 \\
\hline & III & & 27,2 & 0,14 & 13,47 & 13,11 & 8,77 & 30 \\
\hline
\end{tabular}


Tabela 11. Statystyka opisowa parametrów dawek i objętości dla odbytnicy $(\alpha / \beta=3) \mathrm{w}$ trzech grupach wg schematów leczenia.

\begin{tabular}{|c|c|c|c|c|c|c|c|c|}
\hline Parametr & $\begin{array}{c}\text { Grupy } \\
\text { leczenia }\end{array}$ & Jednostki & Maks. & Min. & Średnia & Mediana & SD & $\begin{array}{l}\text { Liczba } \\
\text { frakcji }\end{array}$ \\
\hline \multirow{3}{*}{$D_{10-r}$} & I & \multirow{3}{*}{$\%$} & 98,16 & 42,41 & 62,19 & 59,69 & 13,86 & 37 \\
\hline & II & & 79,69 & 50,56 & 63,08 & 63,56 & 8,87 & 36 \\
\hline & III & & 74,52 & 53,09 & 65,21 & 66,12 & 6,82 & 30 \\
\hline \multirow{3}{*}{$\mathrm{BED}_{10-\mathrm{r}}$} & $\mathrm{I}$ & \multirow{3}{*}{ Gy } & 88,34 & 38,17 & 55,96 & 53,72 & 12,48 & 37 \\
\hline & II & & 34,51 & 21,89 & 27,31 & 27,53 & 3,84 & 36 \\
\hline & III & & 67,07 & 47,78 & 58,69 & 59,51 & 6,14 & 30 \\
\hline \multirow{3}{*}{$D_{\text {max-r }}$} & I & \multirow{3}{*}{$\%$} & 206,57 & 57,58 & 90,76 & 84,8 & 31,77 & 37 \\
\hline & II & & 132,72 & 68,39 & 90,85 & 90,95 & 19,28 & 36 \\
\hline & III & & 104,03 & 72,38 & 84,68 & 80,3 & 12,53 & 30 \\
\hline \multirow{3}{*}{$\mathrm{BED}_{\text {max-r }}$} & $\mathrm{I}$ & \multirow{3}{*}{ Gy } & 185,91 & 51,82 & 81,69 & 76,32 & 28,6 & 37 \\
\hline & II & & 57,46 & 29,61 & 39,34 & 39,38 & 8,35 & 36 \\
\hline & III & & 93,63 & 65,14 & 76,21 & 72,27 & 11,28 & 30 \\
\hline \multirow{3}{*}{$D_{\text {min-r }}$} & I & \multirow{3}{*}{$\%$} & 46,84 & 13,55 & 23,12 & 19,89 & 7,87 & 37 \\
\hline & II & & 38,57 & 16,54 & 23,39 & 21,76 & 5,49 & 36 \\
\hline & III & & 29,68 & 19,71 & 25,13 & 25,59 & 3,96 & 30 \\
\hline \multirow{3}{*}{$\mathrm{BED}_{\text {min-r }}$} & I & \multirow{3}{*}{ Gy } & 42,16 & 12,2 & 20,81 & 17,9 & 7,08 & 37 \\
\hline & II & & 16,71 & 7,17 & 10,13 & 9,43 & 2,38 & 36 \\
\hline & III & & 26,71 & 18,09 & 22,72 & 23,03 & 3,42 & 30 \\
\hline \multirow{3}{*}{$\mathrm{D}_{\text {mean-r }}$} & I & \multirow{3}{*}{$\%$} & 75,11 & 29,07 & 46,06 & 44,02 & 11,86 & 37 \\
\hline & II & & 64,4 & 35,56 & 46,27 & 46,44 & 7,21 & 36 \\
\hline & III & & 56,58 & 44,14 & 49,35 & 47,94 & 4,55 & 30 \\
\hline \multirow{3}{*}{$\mathrm{BED}_{\text {mean-r }}$} & I & \multirow{3}{*}{ Gy } & 67,6 & 26,16 & 41,46 & 39,62 & 10,68 & 37 \\
\hline & II & & 27,9 & 15,4 & 20,04 & 20,11 & 3,12 & 36 \\
\hline & III & & 50,9 & 39,73 & 44,38 & 42,97 & 4,1 & 30 \\
\hline \multirow{3}{*}{$\mathrm{SD}_{-\mathrm{r}}$} & I & \multirow{3}{*}{$\%$} & 18,69 & 7,77 & 11,59 & 11,26 & 2,692 & 37 \\
\hline & II & & 15,16 & 8,84 & 11,67 & 10,83 & 2,03 & 36 \\
\hline & III & & 14,69 & 8,99 & 12,4 & 12,83 & 2,21 & 30 \\
\hline \multirow{3}{*}{$\mathrm{V}_{100-\mathrm{r}}$} & $\mathrm{I}$ & \multirow{3}{*}{$\%$} & 8,73 & 0 & 0,43 & 0,38 & 1,68 & 37 \\
\hline & II & & 2,37 & 0 & 0,23 & 0,22 & 0,56 & 36 \\
\hline & III & & 0,89 & 0 & 0,18 & 0,2 & 0,3 & 30 \\
\hline \multirow{3}{*}{$\mathrm{V}_{\text {crit-r }}$} & I & \multirow{3}{*}{$\%$} & 25,1 & 0 & 1,98 & 1,5 & 5,41 & 37 \\
\hline & II & & 4,92 & 0 & 0,93 & 0,12 & 1,54 & 36 \\
\hline & III & & 4,27 & 0 & 1,26 & 0,24 & 1,68 & 30 \\
\hline
\end{tabular}




\subsection{Porównanie zmienności wartości dawek i objętości w obrębie grup pacjentów.}

Analizę parametrów DVH pomiędzy frakcjami dla gruczołu krokowego oraz organów otaczających, wykonano niezależnie od porównania parametrów planu leczenia zastosowanego w różnych schematach. Do obliczeń statystycznych użyto median parametrów I i II frakcji w II grupie leczenia skojarzonego oraz I, II i III w grupie samodzielnej brachyterapii HDR. W tej części nie analizowano wartości DVH dla grupy I (tylko jedna frakcja leczenia). Celem porównania parametrów planu było określenie mechanizmów zmiany wartości objętości i dawek w gruczole krokowym w trakcie stosowania dwóch i trzech frakcji i ich wpływu na parametry cewki moczowej i odbytnicy. Poszczególne wartości DVH dla gruczołu krokowego (targetu) podzielono na potrzeby analizy na trzy grupy: I odpowiadające za prawidłowe deponowanie dawki referencyjnej we właściwej objętości gruczołu ( $\mathrm{D}_{90-\mathrm{p}}, \mathrm{BED}_{90-\mathrm{p}} \mathrm{V}_{100-\mathrm{p}}, \mathrm{SD}_{-\mathrm{p}}$, $\mathrm{D}_{\text {mean-p }}$, $\mathrm{BED}_{\text {mean-p }}$ ), II - wartości dawek i objętości w tzw. punktach gorących o wartości przekraczającej dawkę referencyjną $\left(\mathrm{V}_{200-\mathrm{p}}, \mathrm{V}_{150-\mathrm{p}}, \mathrm{V}_{120-\mathrm{p}}\right.$, $\left.\mathrm{D}_{\text {max-p }}, \mathrm{BED}_{\max -\mathrm{p}}\right)$ oraz III - wartości dawek minimalnych $\left(\mathrm{D}_{\min -\mathrm{p}}, \mathrm{BED}_{\min -\mathrm{p}}\right)$ informujące o możliwym stopniu niedopromienienia gruczołu (tzw. punkty zimne). Dla organów okolicznych, takich jak cewka moczowa i odbytnica, które z założenia powinny otrzymać jak najmniejszą dawkę promieniowania podczas brachyterapii HDR, analizę parametrów skoncentrowano na wysokości dawek w ich obrębie w odniesieniu do pożądanych dawek referencyjnych targetu. Oceniono parametry podstawowe akceptacji planu leczenia jak: $\mathrm{D}_{10-}$ u,r, $\mathrm{BED}_{10-\mathrm{u}, \mathrm{r}}$ i $\mathrm{D}_{\text {max-u,r, }}, \mathrm{BED}_{\text {max-u,r }}$ oraz pomocnicze: $\mathrm{V}_{100-\mathrm{u}, \mathrm{r}}, \mathrm{D}_{\text {mean-u,r, }}, \mathrm{BED}_{\text {mean-u,r, }}, \mathrm{SD}_{\text {-u,r, }}, \mathrm{V}_{\text {crit-u,r. }}$ Wartości parametrów dawek i objętości planu leczenia w poszczególnych frakcjach z uwzględnieniem porównań statystycznych zebrano w tabeli 12 . 
Tabela 12. Porównanie parametrów dawek i objętości w zależności od liczby frakcji dla gruczołu krokowego $(\alpha / \beta=1,5)$, cewki moczowej, odbytnicy $(\alpha / \beta=3)$ w odpowiednich grupach.

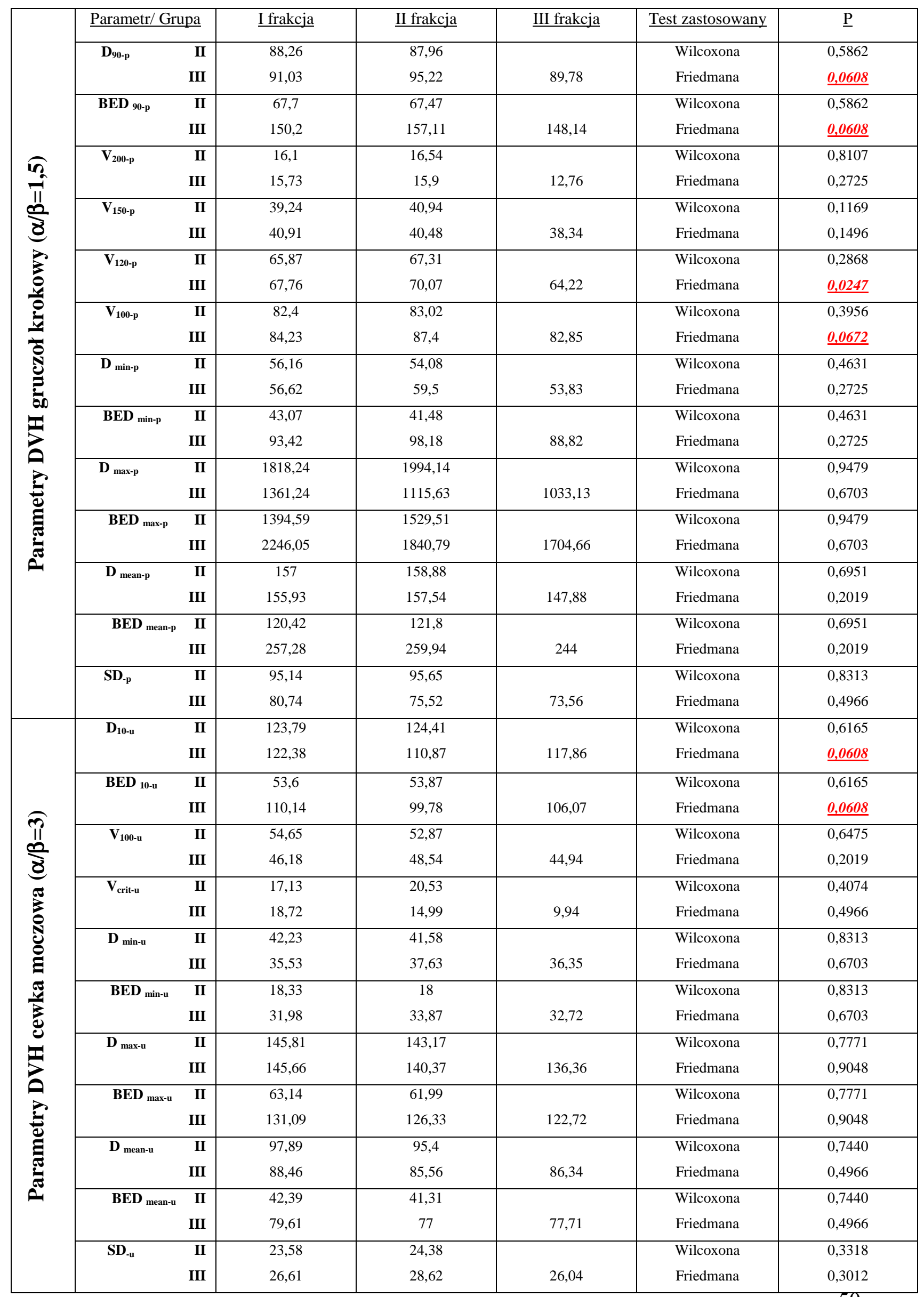




\begin{tabular}{|c|c|c|c|c|c|c|}
\hline \multirow{23}{*}{ 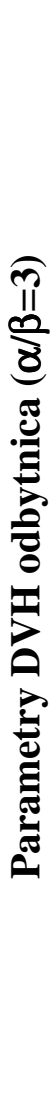 } & Parametr/ Grupa & I frakcja & II frakcja & III frakcja & Test zastosowany & $\underline{\mathrm{P}}$ \\
\hline & D $_{10-r} \quad$ II & 62,91 & 63,25 & & Wilcoxona & 0,7113 \\
\hline & III & 61,75 & 66,53 & 67,35 & Friedmana & 0,3012 \\
\hline & BED $_{10-\mathrm{r}}$ & 27,24 & 27,39 & & Wilcoxona & 0,7113 \\
\hline & III & 55,58 & 59,88 & 60,62 & Friedmana & 0,3012 \\
\hline & $V_{100-r}$ & 0,42 & 0,034 & & Wilcoxona & 0,0687 \\
\hline & III & 0,041 & 0,175 & 0,316 & Friedmana & 0,5258 \\
\hline & $\mathbf{V}_{\text {crit-r }} \quad$ II & 1,09 & 0,76 & & Wilcoxona & 0,5525 \\
\hline & III & 0,58 & 1,42 & 1,71 & Friedmana & 0,1401 \\
\hline & $D_{\text {min-r }}$ & 23,74 & 23,03 & & Wilcoxona & 0,7275 \\
\hline & III & 25,24 & 27,27 & 22,89 & Friedmana & 0,2019 \\
\hline & BED $_{\text {min-r }}$ II & 10,28 & 9,97 & & Wilcoxona & 0,7275 \\
\hline & III & 22,72 & 24,54 & 20,6 & Friedmana & 0,2019 \\
\hline & $D_{\text {max-r }}$ & 94,86 & 86,84 & & Wilcoxona & 0,4997 \\
\hline & III & 72,83 & 77,46 & 95,72 & Friedmana & 0,1496 \\
\hline & BED $_{\text {max-r }}$ II & 41,07 & 37,6 & & Wilcoxona & 0,4997 \\
\hline & III & 65,55 & 69,71 & 86,15 & Friedmana & 0,1496 \\
\hline & $\mathbf{D}_{\text {mean-r }} \quad$ II & 43,39 & 46,65 & & Wilcoxona & 0,4724 \\
\hline & III & 46,56 & 51,96 & 49,52 & Friedmana & 0,3012 \\
\hline & BED mean-r $_{\text {II }}$ II & 18,79 & 20,2 & & Wilcoxona & 0,4724 \\
\hline & III & 41,9 & 46,76 & 44,57 & Friedmana & 0,3012 \\
\hline & SD-r $_{\text {-r }}$ & 11,6 & 11,74 & & Wilcoxona & 0,6791 \\
\hline & III & 10,98 & 12,3 & 13,36 & Friedmana & 0,4966 \\
\hline
\end{tabular}

\subsubsection{Zmienność wartości dawek i objętości w grupie II.}

Wartości dawek biologicznych i objętości planu leczenia rozpatrywane pomiędzy dwiema frakcjami 10 Gy w grupie II okazały się bardzo jednorodne. Porównując ich wielkości w pierwszej i drugiej frakcji leczenia, w żadnym przypadku nie znaleziono istotnych statystycznie różnic. Wyjątkiem od tej reguły może być parametr objętości dla odbytnicy $\left(\mathrm{V}_{100-\mathrm{r}}\right)$ gdzie wartość p bliska była istotności statystycznej. Rozpatrując pierwsze frakcje brachyterapii HDR należy pamiętać o fakcie uprzedniego napromienienia pacjentów stosunkowo niską dawką z teleradioterapii (EBRT) - 46 Gy, ze stosunkowo niskimi dawkami w obrębie cewki i odbytnicy. Parametry odpowiadające za precyzję brachyterapii zmian nowotworowych w pierwszej frakcji okazały się suboptymalne. Mediana wartości parametru

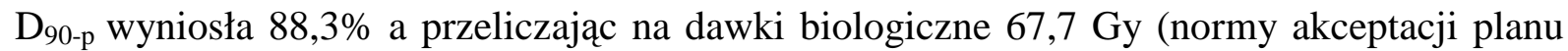
leczenia odpowiednio 90\% i 76,6 Gy). Stosunkowo niska okazała się również wartość 
objętości dawki 100\% ( $\left.\mathrm{V}_{100-p}\right)$, która wyniosła 82,4\%. Dawka średnia ( $\mathrm{D}_{\text {mean-p }}$, BED $\left.\mathrm{B}_{\text {mean-p }}\right)$ przekraczała jednak wielokrotnie zadaną dawkę referencyjną (odpowiednio 157\% oraz 120,4 Gy). Wysoka wartość odchylenia standardowego $\left(\mathrm{SD}_{-\mathrm{p}}\right)-95,1 \%$, sugerowała istnienie punktów w obrębie gruczołu krokowego o dawce odbiegającej znacząco od średniej (tzw. punkty gorące i zimne). Parametry opisujące możliwość podania zbyt wysokiej dawki w trakcie leczenia okazały się w w pierwszej frakcji nieznacznie zawyżone $\left(\mathrm{V}_{200-p}-16,1 \%\right.$, $\mathrm{V}_{150-\mathrm{p}}-39,2 \%, \mathrm{~V}_{120-\mathrm{p}}-65,9 \%, \mathrm{D}_{\text {max-p }}-1818,2 \%$, BED max-p $-1394,6$ Gy). Dawka minimalna $\left(\mathrm{D}_{\text {min-p}}, \mathrm{BED}_{\text {min-p }}\right)$, pośrednio określająca punkty o niższej niż zakładana dawce wyniosła odpowiednio 56,2\% i 43,1 Gy. Bardzo korzystny okazał się rozkład dawek w obrębie cewki moczowej, nawet bez uwzględnienia niskiej dawki frakcyjnej w tej grupie. Wartości parametrów $\mathrm{D}_{10 \text {-u }}$ oraz $\mathrm{BED}_{10 \text {-u }}(123,8 \%, 53,6 \mathrm{~Gy})$ nie przekraczały przyjętych dawek ograniczających $\left(\mathrm{D}_{10-\mathrm{u}}-130 \%\right.$ oraz $\left.\mathrm{BED}_{10-\mathrm{u}}-56,3 \mathrm{~Gy}\right)$. Dawka maksymalna wyniosła dla pierwszej frakcji 145,8\% i 63,1 Gy i nie naruszała zasad akceptacji planu brachyterapii HDR (normy odpowiednio poniżej 165\% i 71,5 Gy). Zwracała uwagę dość niska wartość odchylenia standardowego $\left(\mathrm{SD}_{-\mathrm{u}}-23,6 \%\right)$. Pozostałe wartości parametrów cewki moczowej, mniej istotne w ocenie planu $\left(\mathrm{V}_{100-\mathrm{u}}, \mathrm{D}_{\text {min-u }}, \mathrm{BED}_{\text {min-u }}, \mathrm{D}_{\text {mean-u}}, \mathrm{BED}_{\text {mean-u}}, \mathrm{V}_{\text {crit-u }}\right)$ nie odbiegały od wartości ogólnie przyjętych. Przy analizie parametrów brachyterapii HDR odbytnicy w grupie II, wyraźnie podwyższona okazała się wartość dawki maksymalnej $\left(\mathrm{D}_{\max -\mathrm{r}}-94,9 \%\right.$, $\left.\mathrm{BED}_{\text {max-r }}-41,1 \mathrm{~Gy}\right)$ przy normie odpowiednio $<85 \%$ i 36,8 Gy. Faktem świadczącym o podaniu dawki wysokiej na niewielkim obszarze odbytnicy jest niski parametr $\mathrm{SD}_{\text {-r }}(11,6 \%)$. Powodem akceptacji otrzymanych dawek była prawidłowa wartość $\mathrm{D}_{10-\mathrm{r}} \mathrm{i}$ BED $\mathrm{BE}_{10-\mathrm{r}}(62,9 \%$ i 27,2 Gy).

Pomimo faktu niskiej dawki frakcyjnej oraz najniższej, biologicznej dawki całkowitej w trzech grupach (tabela 5), wykonujący zabieg brachyterapii HDR starali się zmniejszyć w drugiej frakcji wysokość dawki w odbytnicy. Dawka maksymalna uległa zmniejszeniu do $86,8 \%$ a $\mathrm{BED}_{10-\mathrm{r}}$ do $37,6 \mathrm{~Gy}$ a zmiana ta porównując parametry w obu frakcjach nie okazała się istotna statystycznie ( $\mathrm{p}=0,4997$, w teście Wilcoxona). Kierunek dążenia radioterapeutów do redukcji dawki w odbytnicy może potwierdzać fakt granicznej istotności statystycznej porównań dla parametru objętości dawki $100 \%\left(\mathrm{~V}_{100-\mathrm{r}}\right)$. Zmiana wartości 0,4\% w pierwszej frakcji na $0,03 \% \mathrm{z}$ poziomem istotności $\mathrm{p}=0,0687$, sugeruje zmniejszenie dawki, ciągle jednak nieistotne statystycznie (rycina 2). 
Rycina 2. Porównanie wartości parametru dla odbytnicy $\mathrm{V}_{100-\mathrm{r}}$ pomiędzy dwiema frakcjami, II grupa.

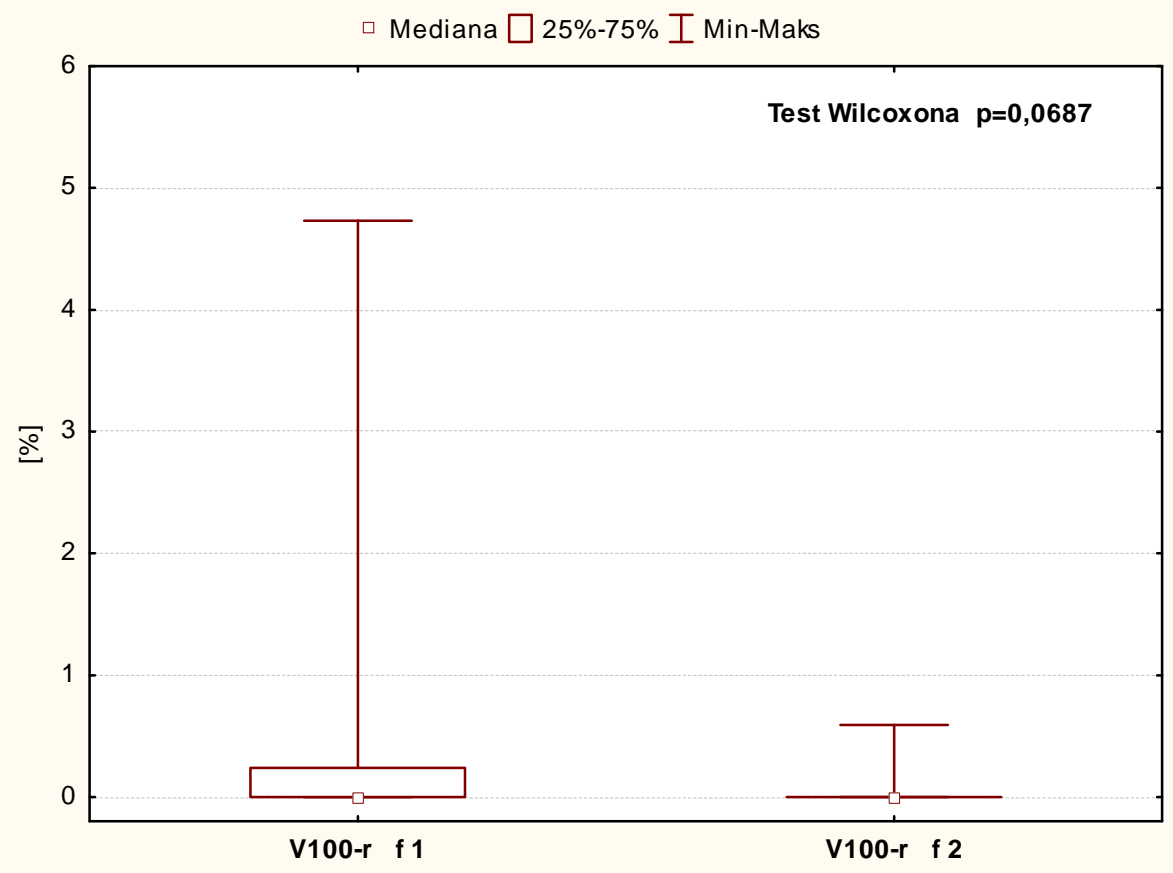

Zaobserwowana powyżej prawidłowość spowodowała nieznaczne podwyższenie parametru $\mathrm{D}_{10-\mathrm{r}} \mathrm{i} \mathrm{BED}_{10-\mathrm{r}}$ do odpowiednio 63,3\% i 27,4 Gy w sposób nieistotny statystycznie ( $\mathrm{p}=0,7113$ ). Podwyższeniu uległa ponadto dawka średnia $\left(\mathrm{D}_{\text {mean-r }}, \mathrm{BED}_{\text {mean-r }}\right)$ do 46,7\% i 20,2 Gy $(\mathrm{p}=0,4724)$, mniejsza natomiast okazała się wartość objętości krytycznej, przekraczającej założenia systemu planowania leczenia $\left(\mathrm{V}_{\text {crit-r }}-0,8 \%\right)$, przy współczynniku $\mathrm{p}=0,5525$.

Kosztem tej nieistotnej statystycznie poprawy wartości dawek w odbytnicy było nieznaczne pogorszenie parametrów w obrębie gruczołu krokowego. Spadek $\mathrm{D}_{90-\mathrm{p}}$ i BED 90-p $_{\text {do }}$ odpowiednio $88 \%$ i 67,5 Gy był niewielki i nieistotny ( $\mathrm{p}=0,6852)$. Parametry punktów dawek o wyższych wartościach niż zakładane w II frakcjach okazały się wyższe, odpowiednio dla każdego z nich: $\mathrm{V}_{200-\mathrm{p}}-16,5 \%(\mathrm{p}=0,8107), \mathrm{V}_{150-\mathrm{p}}-40,9 \%(\mathrm{p}=0,1169), \mathrm{V}_{120-\mathrm{p}}-67,3 \%$ $(\mathrm{p}=0,2868)$ oraz $\mathrm{D}_{\max -\mathrm{p}}-1994,1 \%, \mathrm{BED}_{\max -\mathrm{p}}-1529,5 \mathrm{~Gy}(\mathrm{p}=0,7771)$.

Obniżeniu ponadto uległa dawka minimalna $\mathrm{D}_{\text {min-p }}$ oraz $\mathrm{BED}_{\text {min-p }}$, także przy braku istotności statystycznej testu Wilcoxona $(\mathrm{p}=0,4631)$.

Zmniejszenie dawek w odbytnicy powoduje oszczędzenie cewki moczowej jako organu ryzyka. Zauważono zmniejszenie dawek maksymalnych $\mathrm{D}_{\max -\mathrm{u}}, \mathrm{BED}_{\max \text {-u }}(143,2 \%, 62 \mathrm{~Gy})$, $\mathrm{V}_{100-\mathrm{u}}(52,9 \%)$ oraz $\mathrm{D}_{\text {mean-u }}, \mathrm{BED}_{\text {mean-u }}(95,4 \%$ i 41,3 Gy) ponownie, bez wykazania istotności statystycznej (odpowiednio: $\mathrm{p}=0,7771,0,6475,0,7440$ ). 


\subsubsection{Zmienność wartości dawek i objętości w grupie III.}

W odróżnieniu od grupy II, brachyterapia HDR złożona z wysokich dawek frakcyjnych stanowiła tutaj jedyną formę leczenia promieniowaniem jonizującym (BED=495 Gy). $\mathrm{Z}$ drugiej strony do grupy monoterapii HDR-BRT, oprócz nielicznych wyjątków, zakwalifikowani zostali pacjenci o niskim zaawansowaniu klinicznym i dobrym rokowaniu. Zachodziła więc szczególna konieczność uwagi na wysokości dawek w obrębie gruczołu krokowego oraz narządów krytycznych aby uniknąć późnych powikłań popromiennych w obrębie tych narządów.

Rozpatrując parametry istotne dla prawidłowego deponowania dawki na guz nowotworowy określono w dwóch pierwszych frakcjach wartości $\mathrm{D}_{90-\mathrm{p}}$ oraz $\mathrm{BED}_{90-\mathrm{p}}$ jako akceptowalne dla planu leczenia (odpowiednio 91\%, 95,2\% oraz 150,2 Gy, 157,1 Gy). Wartości procentowe objętości dawki $100 \%\left(\mathrm{~V}_{100-p}\right)$ w porównaniu z grupą II były nieznacznie korzystniejsze i wynosiły $84,2 \%$ i $87,4 \%$. W pierwszych frakcjach monoterapii HDR zaobserwowano ponadto mniejsze parametry odchylenia standardowego $\mathrm{SD}_{-\mathrm{p}}(80,7 \%$ i $75,5 \%)$, bardziej jednorodną dawkę promieniowania $\mathrm{w}$ obrębie targetu, w porównaniu $\mathrm{z}$ grupą poprzednią. Dawka BED $_{\text {mean-p }}$ wyniosła dla każdej z frakcji odpowiednio 257,3 Gy i 259,9 Gy, przekraczając założoną dawkę referencyjną (Dref 100\% - 165 Gy). Wysokie objętości dawek w punktach gorących okazały się akceptowalne granicznie pod kątem planu leczenia $\left(\mathrm{V}_{200-p}=15,7 \%\right.$ i $15,9 \%, \mathrm{~V}_{150-\mathrm{p}}=40,9 \%, 40,5 \%, \mathrm{~V}_{120-\mathrm{p}}=67,8 \%$ i 70,1\%). Dawka maksymalna, wyraźnie niższa procentowo $\left(\mathrm{D}_{\text {max }-\mathrm{p}}=1361,2 \%\right.$ i $1115,6 \%, \mathrm{BED}_{\max -\mathrm{p}}=2246,1$ Gy i $\left.1840,8 \mathrm{~Gy}\right) \mathrm{z}$ racji 15 Gy dawki frakcyjnej okazała się wysoka, w porównaniu z grupą II. Dawka minimalna $\left(\mathrm{D}_{\text {min-p }}\right)$ nie odbiegała od wyników obserwowanych w poprzedniej analizie i wynosiła odpowiednio dla I i II frakcji leczenia 56,6\% i 59,5\%. Korzystne parametry optymalizacyjne w obrębie cewki moczowej nie powodowały konieczności korekty w trzeciej frakcji brachyterapii. Kluczowy parametr $\mathrm{D}_{10-\mathrm{u}}$ oraz $\mathrm{BED}_{10 \text {-u }} \mathrm{w}$ każdej z frakcji okazał się poniżej normy $(122,4 \%, 110,9 \% \mathrm{i}$ 110,1 Gy, 99,8 Gy), parametr dawki maksymalnej $\mathrm{D}_{\max -\mathrm{u}}$, $\operatorname{BED}_{\max -\mathrm{u}}(145,7 \%, 140,4 \%$ i 131,1 Gy, 126,3 Gy) umożliwiał akceptację planu. W obrębie tego narządu krytycznego uwagę zwraca niska procentowo dawka średnia ( $D_{\text {mean-u }} 88,5 \%$ i 85,6\%), niska objętość $V_{100-u} 46,2 \%$ i 48,5\%), wyższa wartość odchylenia standardowego $\left(\mathrm{SD}_{-\mathrm{u}} 26,6 \%\right.$ i $\left.28,6 \%\right)$ w porównaniu z grupą leczenia skojarzonego. Wartości parametrów $\mathrm{D}_{10-\mathrm{r}}$ i $\mathrm{BED}{ }_{10-\mathrm{r}}$ dla odbytnicy z frakcji na frakcję wzrastały (61,8\% i 66,6\% oraz 55,6 Gy i 59,9 Gy), przekraczając nieznacznie dopuszczalne wielkości dawek. Zaobserwowane dawki maksymalne skłaniały jednak do akceptacji i kontynuowania leczenia $\left(D_{\text {max-r }} w\right.$ obu frakcjach poniżej $85 \%$ dawki 
referencyjnej). Wraz z kluczowymi parametrami rosły także dawka średnia - $B D_{\text {mean-r }}(41,9$ Gy - 46,8 Gy), $\mathrm{V}_{100-\mathrm{r}}\left(0,04 \%\right.$ - 0,2\%), $\mathrm{V}_{\text {crit-r }}(0,6 \%$ - 1,4\%).

Analizując statystycznie zmienność w grupie samodzielnej brachyterapii, zauważono w trzeciej frakcji wyraźnie niższe wartości parametrów odpowiadających za punkty dawek wysokich. Objętość dawki 200\% ( $\left.\mathrm{V}_{200-p}\right)$ zmniejszyła się do 12,8\%, ale porównując testem Friedmana wszystkie trzy frakcje leczenia, zmiana nie była istotna statystycznie $(p=0,2725)$. Pozostałe parametry punktów gorących także nie osiągnęły istotności pomimo niższych wartości w ostatniej frakcji $\left(\mathrm{V}_{150-\mathrm{p}}=38,3 \%\right.$ - p=0,1496, $\mathrm{D}_{\text {max-p }}=1033,1 \%, \mathrm{BED}_{\max -\mathrm{p}}=1704,7 \mathrm{~Gy}$ - $\mathrm{p}=0,6703)$. Potwierdzeniem statystycznym zaobserwowanej prawidłowości jest parametr objętości dawki 120\% ( $\left.\mathrm{V}_{120-\mathrm{p}}\right)$, który okazał się istotny w teście Friedmana (rycina 3).

Rycina 3. Porównanie wartości parametru dla $\mathrm{V}_{120-\mathrm{p}} \mathrm{W}$ trzech frakcjach, III grupa.

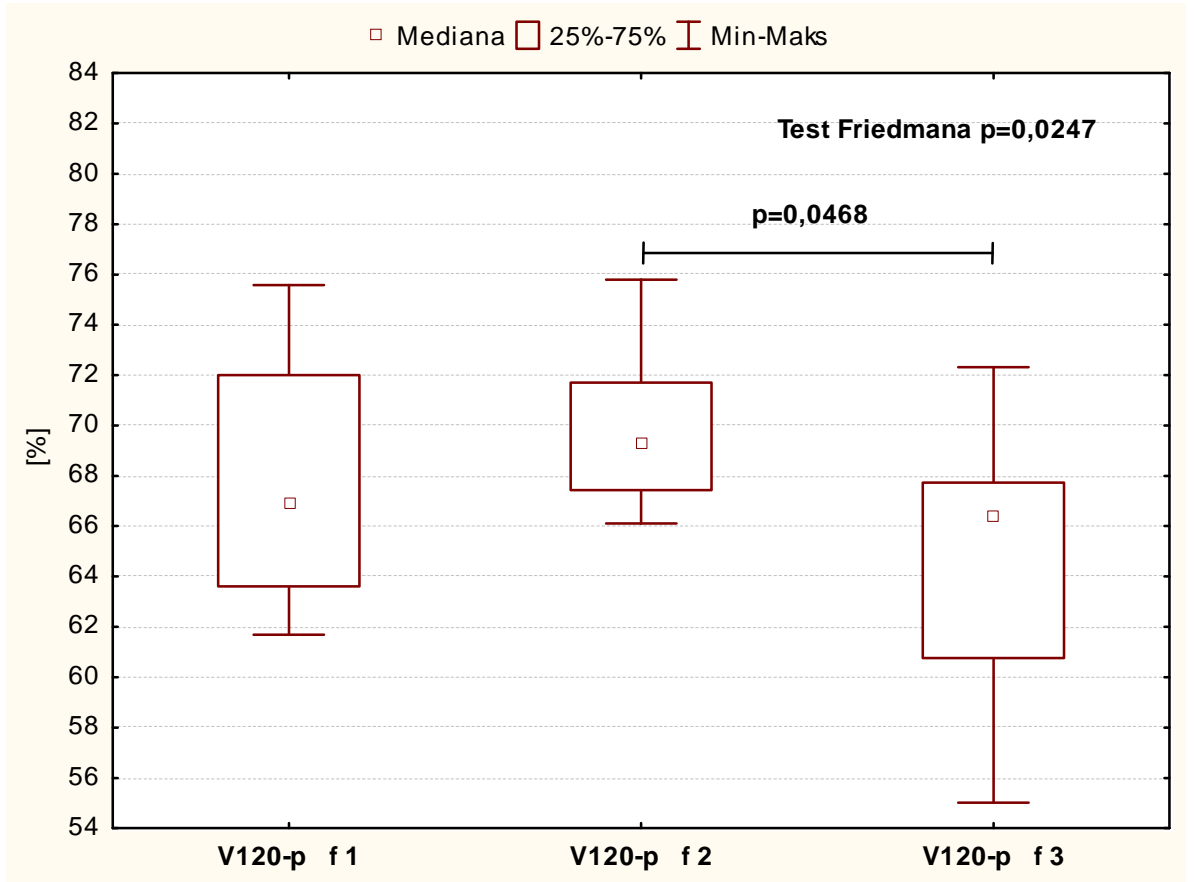

Zmniejszona wartość jednego z tych parametrów objętościowych, w grupie leczenia bardzo wysokimi dawkami frakcyjnymi może świadczyć o tendencji do świadomej korekty planów w trzeciej frakcji celem uniknięcia poważnych powikłań popromiennych. Aby potwierdzić zmienność pomiędzy parametrami w konkretnych frakcjach wykonano test wielokrotnych porównań Dunn'a, który potwierdził istotność statystyczną zmian z drugiej na trzecią frakcję - tabela $13(\mathrm{p}<0,05)$. 
Tabela 13. Porównanie zmienności parametru $\mathrm{V}_{120-\mathrm{p}} \mathrm{W}$ trzech frakcjach brachyterapii, dla III grupy w teście Dunn'a.

\begin{tabular}{|c|c|c|c|}
\hline Porównanie frakcji & Suma & Różnica & Wartość p \\
\hline C1 v C2 & $\begin{array}{l}\text { C1 - 23,00 } \\
\text { C2 - 24,00 }\end{array}$ & $-1,00$ & $>0,05$ \\
\hline $\mathrm{C} 1$ v C3 & $\begin{array}{l}\text { C1 - 23,00 } \\
\text { C3 - 13,00 }\end{array}$ & 10,00 & $>0,05$ \\
\hline $\mathrm{C} 2 \mathrm{v} \mathrm{C3}$ & $\begin{array}{l}\text { C2 - 24,00 } \\
\text { C3 - 13,00 }\end{array}$ & 11,00 & $<0,05$ \\
\hline
\end{tabular}

Dążenie do zmniejszenia objętości dawek wysokich miało wpływ jednocześnie na zmniejszenie wartości parametrów akceptacji dawek na guz nowotworowy, z których najbliżej istotności statystycznej okazały się $\mathrm{D}_{90-p}$ oraz $\mathrm{BED}_{90-\mathrm{p}}$ oraz objętość dawki $100 \%$ $\mathrm{V}_{100-p}$. Wartości dawek obniżyły się nieznacznie poniżej normy prawidłowego planu leczenia (89,8\% i 148,1 Gy w trzeciej frakcji), bez istotności statystycznej (ryciny 4,5). Podobnie $\mathrm{V}_{100-}$ p okazał się najniższy w trzeciej frakcji leczenia (82,9\%), w teście Friedmana porównanie nieistotne statystycznie (rycina 6).

Rycina 4. Porównanie wartości parametru dla $\mathrm{D}_{90-\mathrm{p}} \mathrm{W}$ trzech frakcjach, III grupa.

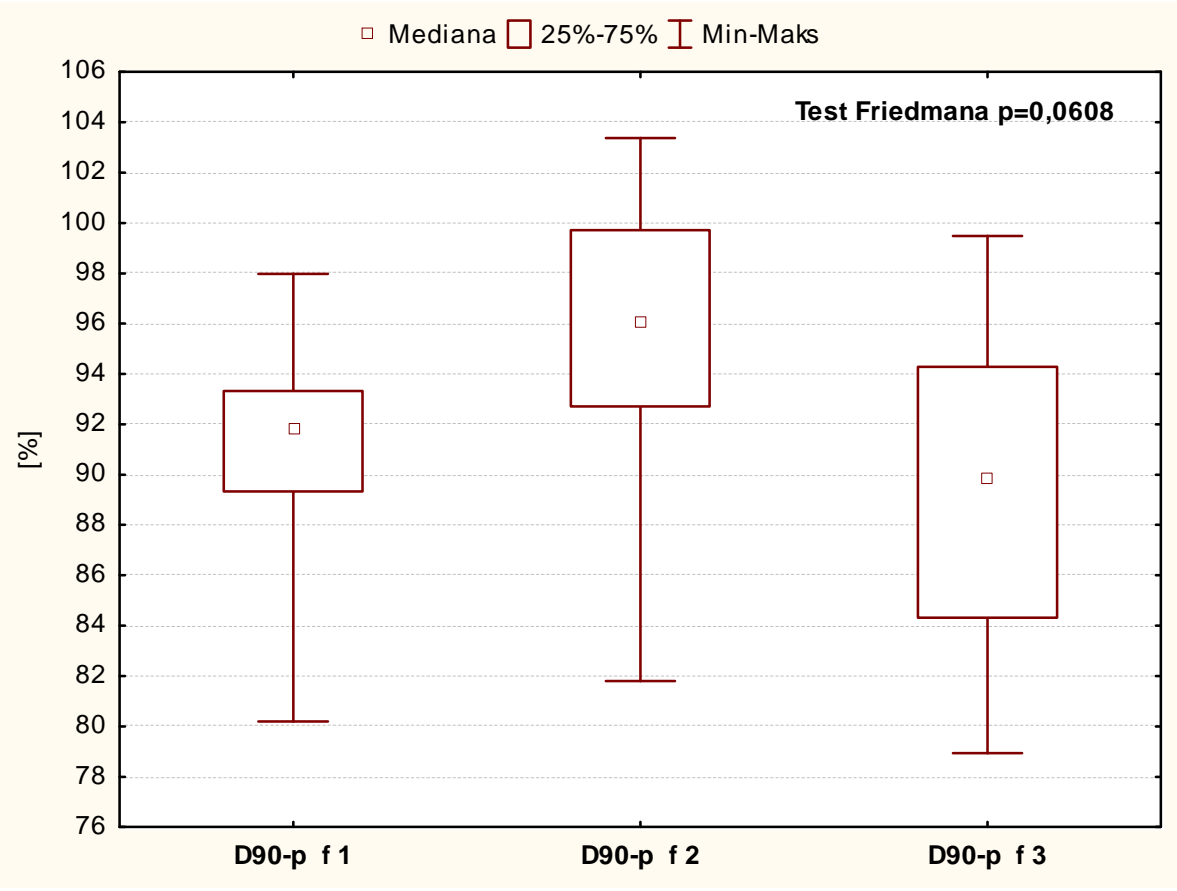


Rycina 5. Porównanie wartości parametru dla $\mathrm{BED}_{90-\mathrm{p}} \mathrm{w}$ trzech frakcjach, III grupa.

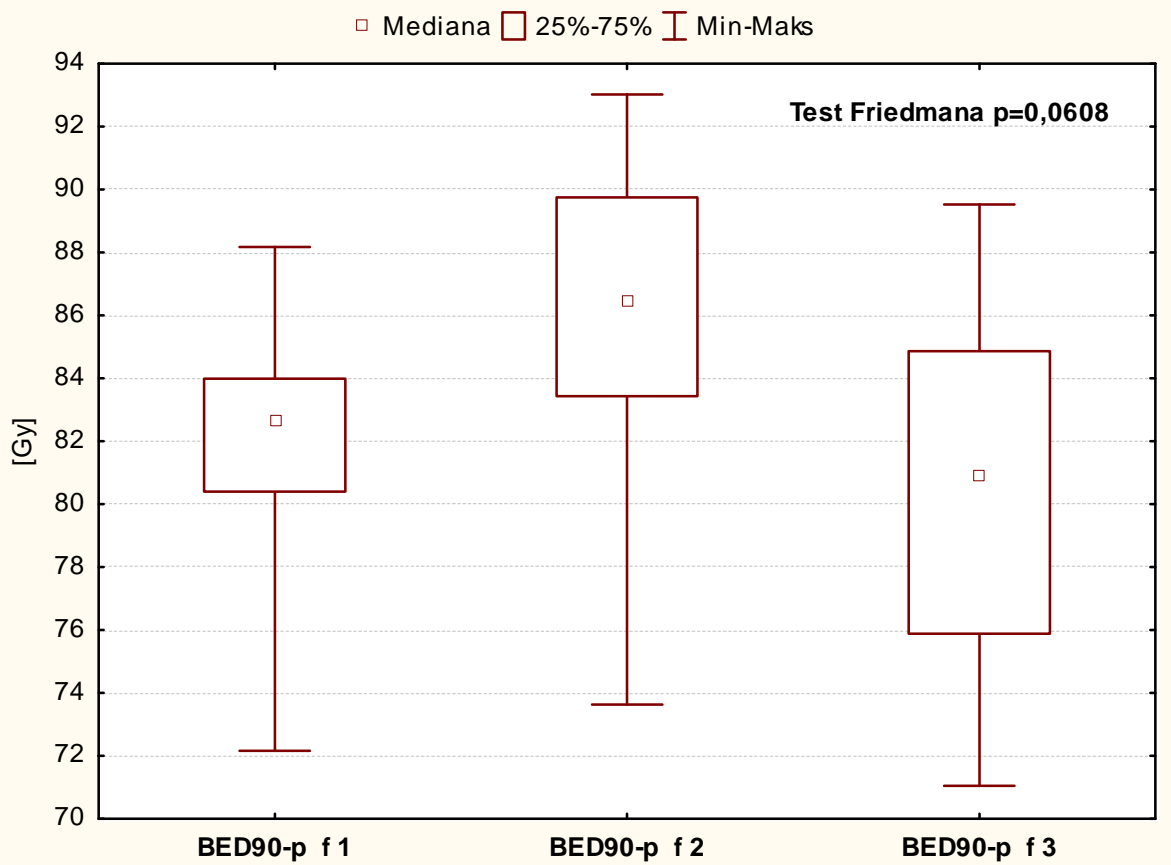

Rycina 6. Porównanie wartości parametru dla $\mathrm{V}_{100-\mathrm{p}} \mathrm{W}$ trzech frakcjach, III grupa

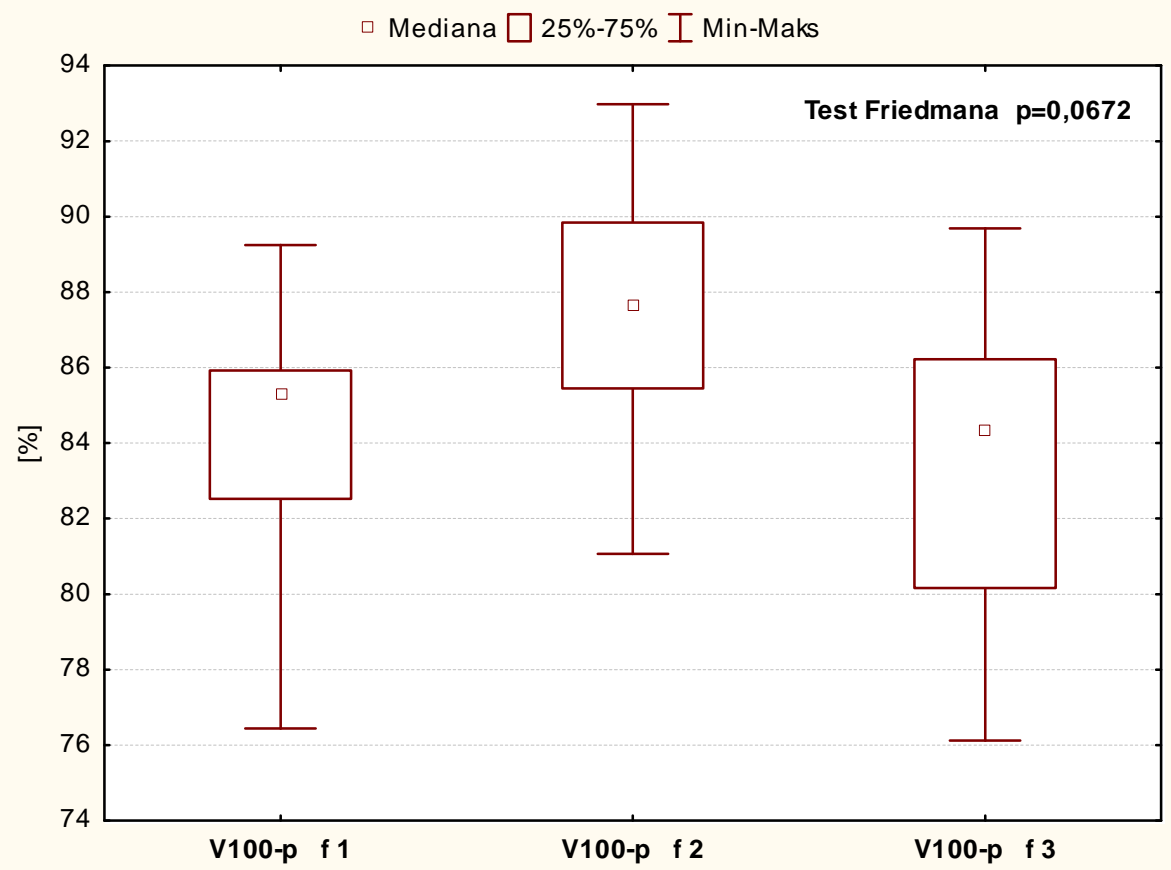


Niezależnie od powyższej próby korekty dawki w obrębie gruczołu krokowego zmniejszały się wartości dawki średniej (147,9\% i 244 Gy) oraz parametr $\mathrm{SD}_{-p}$ (73,6\%) w sposób nieistotny statystycznie (odpowiednio $\mathrm{p}=0,2019$ i 0,4966).

Wartości parametrów dla cewki moczowej zmniejszały się w trzeciej frakcji leczenia, zbieżnie ze spadkiem całkowitej dawki w obrębie gruczołu krokowego. Wartość parametrów $\mathrm{D}_{10 \text {-u }}$ oraz $\mathrm{BED}_{10 \text {-u }}$ obniżyły się $(117,9 \%, 106,1 \mathrm{~Gy})$ różniąc się między sobą, bez istotności statystycznej $(p=0,0608)$. Ryciny 7,8 przedstawiają porównanie median dawek procentowych i biologicznych parametru $\mathrm{D}_{10}$ dla cewki moczowej. Spadek wysokości dawek w obrębie tego organu ryzyka zauważono ponadto $\mathrm{w}$ przypadku $\mathrm{V}_{100-\mathrm{u}}(44,9 \%, \mathrm{p}=0,2019), \mathrm{D}_{\max -\mathrm{u}}, \mathrm{BED}_{\max -\mathrm{u}}$ $(136,4 \%, 122,7 \mathrm{~Gy}, \mathrm{p}=0,9048)$, objętości krytycznej $\mathrm{V}_{\text {crit-u }}(9,9 \%, \mathrm{p}=0,4966)$.

Przeciwnie do cewki moczowej zmniejszenie objętości tzw. punktów gorących w obrębie gruczołu, spowodowało wzrost dawek w odbytnicy. $\mathrm{D}_{10-\mathrm{r}}$ oraz $\mathrm{BED}_{10-\mathrm{r}}$ pozostały na granicznym, wysokim poziomie pod względem akceptacji planu leczenia $(67,4 \%$ oraz 60,6 Gy). W sposób nieistotny statystycznie w teście Friedmana wzrosły: $\mathrm{V}_{100-\mathrm{r}}$ (do 0,3\%), $\mathrm{D}_{\text {max-r }}$ oraz $\mathrm{BED}_{\max -\mathrm{r}}$ (odpowiednio do 95,7\% i 86,2 Gy), $\mathrm{V}_{\text {crit-r }}$ (do 1,7\%). Wartości $\mathrm{p}$ w zastosowanym teście dla powyższych parametrów kształtowały się następująco: $\mathrm{V}_{100-\mathrm{r}}$ $0,5258, \mathrm{D}_{\text {max-r }}, \mathrm{BED}_{\text {max }-\mathrm{r}}-0,1496, \mathrm{~V}_{\text {crit-r }}-0,1401$.

Rycina 7. Porównanie wartości parametru $\mathrm{D}_{10-\mathrm{u}}$ dla cewki moczowej w trzech frakcjach, III grupa.

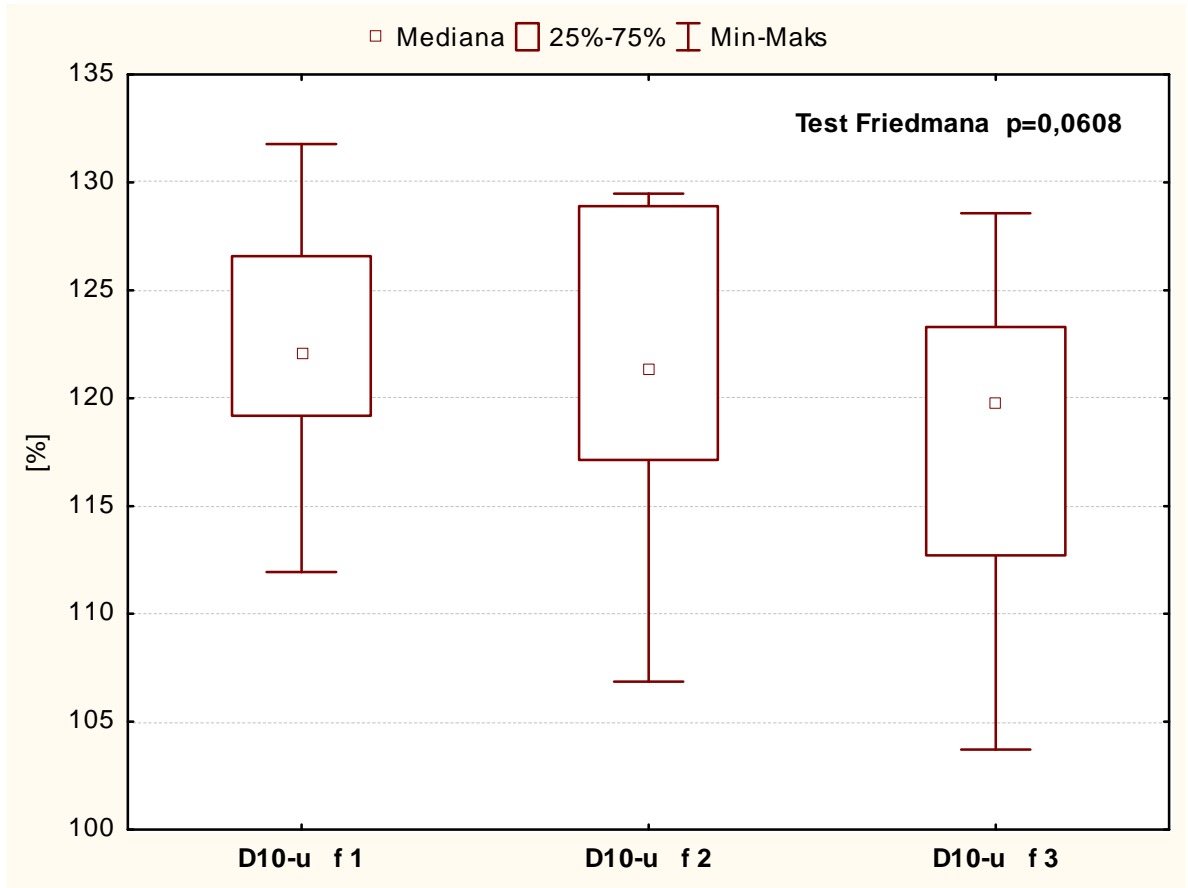


Rycina 8. Porównanie wartości parametru $\mathrm{BED}_{10-\mathrm{u}}$ dla cewki moczowej w trzech frakcjach, III grupa.

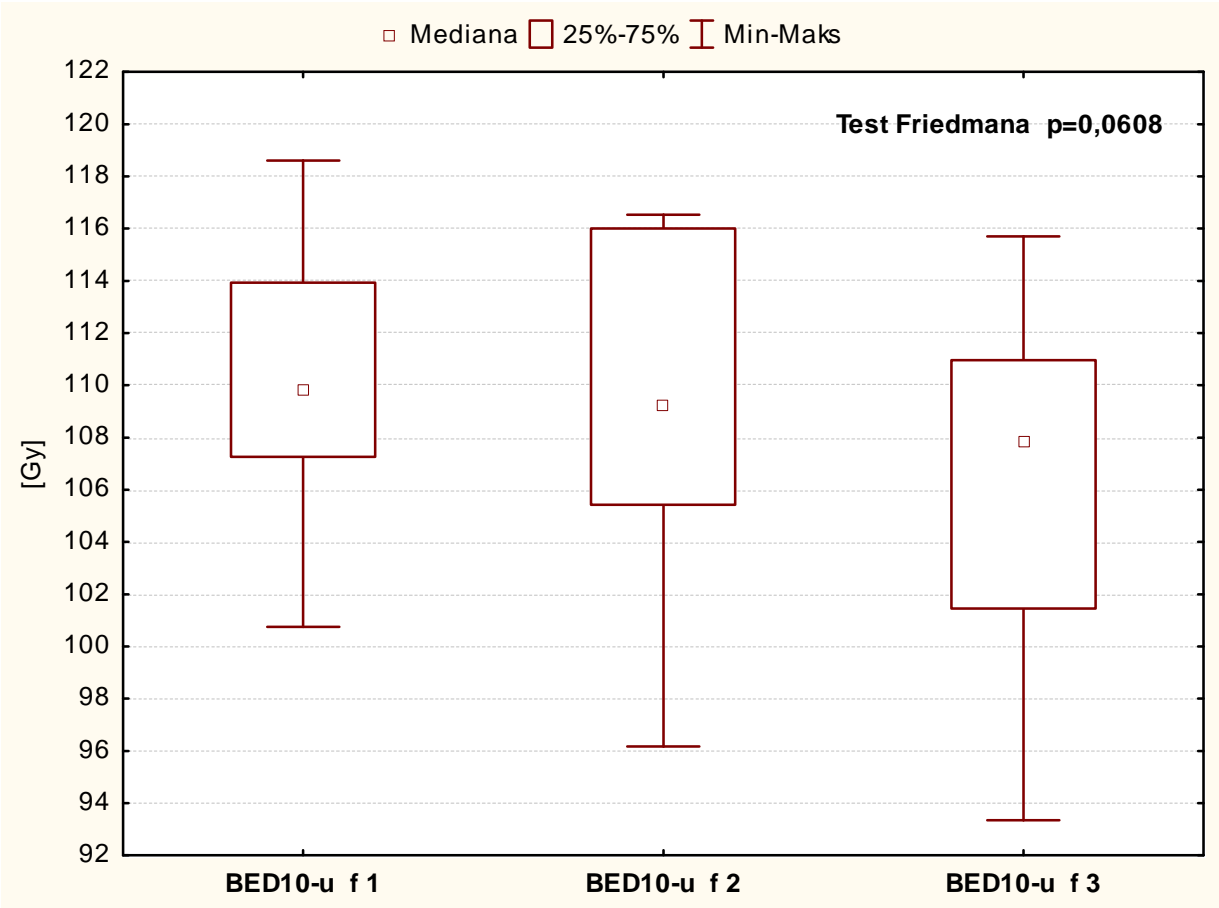




\subsection{Porównanie zmienności średnich wartości dawek i objętości między}

grupami pacjentów.

Tabela 14. Porównanie parametrów dawek i objętości w zależności od schematu brachyterapii HDR dla gruczołu krokowego $(\alpha / \beta=1,5)$, cewki moczowej $(\alpha / \beta=3)$.

\begin{tabular}{|c|c|c|c|c|c|c|c|}
\hline \multirow{14}{*}{ 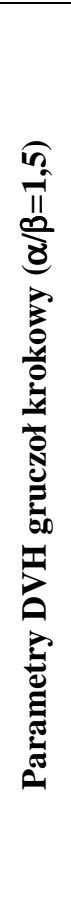 } & Parametr/ Jedn. & I schemat & II schemat & III schemat & & & $\mathbf{P}$ \\
\hline & $D_{90-p}$ & 92,05 & 87,76 & 94,31 & Kruskal-Wallis & & 0,2733 \\
\hline & BED 90-p $_{\text {90 }}$ Gy & 157,88 & $(67,31)$ & 155,31 & Mann-Whitney & $\mathrm{I} / \mathrm{III}$ & 0,6399 \\
\hline & $\begin{array}{ll}V_{200-p} & \%\end{array}$ & 13,5 & 15,93 & 14,71 & Kruskal-Wallis & & 0,2795 \\
\hline & $\mathrm{V}_{150-\mathrm{p}} \quad \%$ & 41,15 & 39,35 & 39,17 & Kruskal-Wallis & & 0,4434 \\
\hline & $\mathrm{V}_{120-p}$ & 70,46 & 67,62 & 68,71 & Kruskal-Wallis & & $\underline{0,0264}$ \\
\hline & $\mathrm{V}_{\text {100-p }}$ & 85,33 & 82,5 & 86,63 & Kruskal-Wallis & & 0,1254 \\
\hline & $D_{\text {min-p }}$ & 55,76 & 55,09 & 58,05 & Kruskal-Wallis & & 0,8409 \\
\hline & BED $_{\text {min-p }} \mathbf{G y}$ & 92 & $(42,25)$ & 95,78 & Mann-Whitney & I/III & 0,8353 \\
\hline & $D_{\text {max-p }}$ & 1066,46 & 1812,24 & 1078,17 & Kruskal-Wallis & & $\underline{0,0011}$ \\
\hline & BED max-p $\mathbf{G y}$ & 1759,56 & $(1389,99)$ & 1778,98 & Mann-Whitney & I/III & 0,9378 \\
\hline & $D_{\text {mean-p }}$ & 152,81 & 155,15 & 155,23 & Kruskal-Wallis & & 0,2533 \\
\hline & BED $_{\text {mean-p }} \quad G y$ & 252,14 & (119) & 256,13 & Mann-Whitney & I/III & 0,6966 \\
\hline & SD $_{\text {-p }}$ & 68,05 & 93,28 & 75,94 & Kruskal-Wallis & & $\underline{0,0011}$ \\
\hline \multirow{11}{*}{ 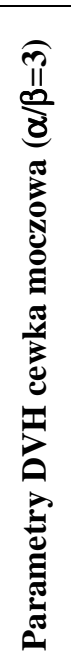 } & $\mathbf{D}_{10-\mathrm{u}}$ & 122,09 & 123,48 & 121,28 & Kruskal-Wallis & & 0,2698 \\
\hline & BED $_{10-\text { u }}$ & 109,88 & $(53,47)$ & 109,15 & Mann-Whitney & I/III & 0,4509 \\
\hline & $\begin{array}{l}V_{100-u} \\
\end{array}$ & 46,12 & 54,20 & 49,33 & Kruskal-Wallis & & 0,0360 \\
\hline & $\mathbf{V}_{\text {crit-u }}$ & 12,78 & 20,19 & 13,11 & Kruskal-Wallis & & 0,3645 \\
\hline & $D_{\text {min-u }}$ & 32,41 & 42,72 & 40 & Kruskal-Wallis & & $\underline{0,0027}$ \\
\hline & BED $_{\text {min-u }}$ & 29,17 & $(18,5)$ & 36 & Mann-Whitney & I/III & 0,2749 \\
\hline & $D_{\text {max-u }}$ & 137,94 & 144,38 & 145,18 & Kruskal-Wallis & & 0,7246 \\
\hline & BED $_{\text {max-u }} \quad$ Gy & 124,15 & $(62,3)$ & 130,78 & Mann-Whitney & $\mathrm{I} / \mathrm{III}$ & 0,9397 \\
\hline & $\mathbf{D}_{\text {mean-u }}$ & 89,34 & 97,69 & 86,96 & Kruskal-Wallis & & $\underline{0,0052}$ \\
\hline & BED $_{\text {mean-u }} \quad \mathbf{G y}$ & 80,41 & $(42,3)$ & 78,27 & Mann-Whitney & I/III & 0,3768 \\
\hline & $\mathrm{SD}_{-\mathrm{u}}$ & 27,27 & 24,26 & 26,8 & Kruskal-Wallis & & 0,0078 \\
\hline
\end{tabular}


Tabela 14 ciąg dalszy. Porównanie średnich parametrów dawek i objętości w zależności od schematu brachyterapii HDR dla odbytnicy $(\alpha / \beta=3)$.

\begin{tabular}{|c|c|c|c|c|c|c|c|}
\hline \multirow{12}{*}{ 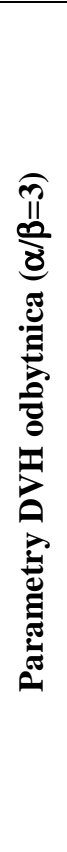 } & Parametr/ Jedn. & \multirow{2}{*}{$\begin{array}{c}\text { I schemat } \\
59,69\end{array}$} & \multirow{2}{*}{$\begin{array}{c}\text { II schemat } \\
63,56\end{array}$} & \multirow{2}{*}{$\begin{array}{c}\text { III schemat } \\
66,12\end{array}$} & \multirow{2}{*}{$\begin{array}{c}\text { Test } \\
\text { zastosowany } \\
\text { Kruskal-Wallis }\end{array}$} & \multicolumn{2}{|c|}{$P$} \\
\hline & $\mathbf{D}_{10-\mathrm{r}}$ & & & & & & 0,5005 \\
\hline & BED $_{10-\mathrm{r}} \quad$ Gy & 53,72 & $(27,53)$ & 59,51 & Mann-Whitney & I/III & 0,2121 \\
\hline & $\mathbf{V}_{100-\mathrm{r}}$ & 0 & 0 & 0 & Kruskal-Wallis & & 0,1359 \\
\hline & $\mathbf{V}_{\text {crit-r }}$ & 0 & 0,12 & 0,24 & Kruskal-Wallis & & 0,2441 \\
\hline & $D_{\text {min-r }}$ & 19,89 & 21,76 & 25,59 & Kruskal-Wallis & & 0,2427 \\
\hline & BED $_{\text {min-r }} \quad \mathbf{G y}$ & 17,9 & $(9,43)$ & 23,03 & Mann-Whitney & I/III & 0,1316 \\
\hline & $D_{\text {max-r }}$ & 84,8 & 90,95 & 80,3 & Kruskal-Wallis & & 0,7118 \\
\hline & BED $_{\text {max-r }}$ Gy & 76,32 & $(39,38)$ & 72,27 & Mann-Whitney & I/III & 0,1200 \\
\hline & $D_{\text {mean-r }}$ & 44,02 & 46,44 & 47,94 & Kruskal-Wallis & & 0,2239 \\
\hline & $\begin{array}{l}\text { BED }_{\text {mean-r }} \\
\\
\text { Gy }\end{array}$ & 39,62 & $(20,11)$ & 42,97 & Mann-Whitney & I/III & 0,1070 \\
\hline & $\mathbf{S D}_{-\mathrm{r}}$ & 11,26 & 10,83 & 12,83 & Kruskal-Wallis & & 0,4337 \\
\hline
\end{tabular}

Porównanie parametrów dawek i objętości pomiędzy schematami leczenia zostało przeprowadzone podobnie jak w przypadku ich analizy wewnątrz grup. Parametry dotyczące gruczołu krokowego podzielono, biorąc pod uwagę fakt prawidłowego podania dawki na okolicę targetu, obecność punktów wysokich dawek jak i miejsc niedopromienionych. Parametry cewki moczowej i odbytnicy wyodrębniono do analizy wysokości dawek podanych na te narządy krytyczne.W porównaniu dawek w schematach leczenia uwzględniono fakt różnych wysokości dawek frakcyjnych (15 Gy w I i III grupie oraz 10 Gy w II). Z tego względu wartości procentowe dawek przeanalizowano testem dla porównań wielokrotnych, zmiennych niezależnych Kruskala-Wallisa (K-W) we wszystkich trzech schematach brachyterapii HDR. Dawki biologiczne zostały porównane testem Manna - Whitneya tylko w grupach z dawką $15 \mathrm{~Gy} /$ frakcję (I i III grupa), ponownie dla zmiennych niezależnych. Różnica w wysokości dawki frakcyjnej może wpływać na parametry dawek i objętości otrzymanych w każdym ze schematów leczenia. Porównanie parametrów $\mathrm{D}_{90-\mathrm{p}}, \mathrm{V}_{100-\mathrm{p}}, \mathrm{SD}_{-\mathrm{p}}$ ujawniło mniej korzystne wartości procentowe dla grupy o niższej dawce frakcyjnej pod kątem prawidłowej dawki podanej na zmianę nowotworową. Średnia $\mathrm{D}_{90-\mathrm{p}} \mathrm{W}$ poszczególnych schematach wynosiła 92,1\%, 87,8\%, 94,3\% a ich zmiana nie okazała się istotna statystycznie w teście $\mathrm{K}-\mathrm{W}(\mathrm{p}=0,2733)$. Podobnie najniższą wartość zaobserwowano w przypadku $\mathrm{V}_{100-\mathrm{p}}$ (grupa II - 82,5\%), w trzeciej grupie nie stwierdzono różnicy $(\mathrm{p}=0,1254)$. Odchylenie 
standardowe dawek $\mathrm{SD}_{-\mathrm{p}} \mathrm{w}$ obrębie guza było najwyższe w grupie dawki 10 Gy (rycina 9), stanowiąc najmniej korzystną wartość z analizowanych (I - 68,5\%, II - 93,3\%, III - 75,9\%). W przypadku tego parametru wykazano istotność w teście Kruskala-Wallisa $(\mathrm{p}=0,0011)$, potwierdzona w teście wielokrotnych porównań Dunn’a dla I i II schematu (tabela 15).

Rycina 9. Porównanie wartości parametru dla $\mathrm{SD}_{-\mathrm{p}} \mathrm{w}$ trzech schematach brachyterapii HDR.

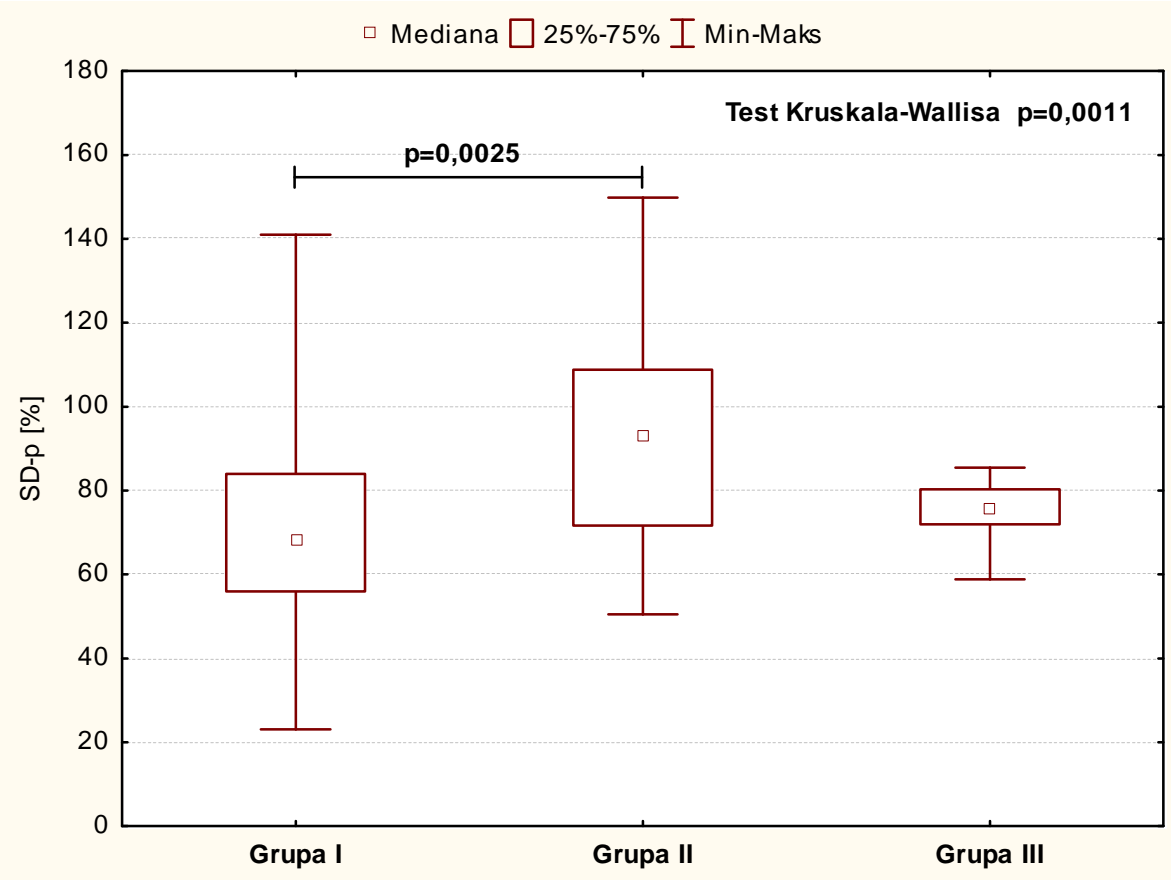

Tabela 15. Porównanie zmienności parametru $\mathrm{SD}_{-\mathrm{p}}$ w trzech schematach brachyterapii HDR w teście Dunn'a.

\begin{tabular}{|c|c|c|c|}
\hline Porównanie schematów & Suma & Różnica & Wartość p \\
\hline I v II & $\begin{array}{c}\text { I - 26,95 } \\
\text { II }-45,11\end{array}$ & $-18,16$ & $<0,05$ \\
\hline II v III & $\begin{array}{l}\text { II }-45,11 \\
\text { III }-33,6\end{array}$ & 11,51 & $>0,05$ \\
\hline I v III & $\begin{array}{l}\text { I }-26,95 \\
\text { III }-33,6\end{array}$ & $-6,65$ & $>0,05$ \\
\hline
\end{tabular}

Analiza tzw. punktów gorących w trzech schematach leczenia nie daje jednoznacznych wniosków. Biorąc pod uwagę parametry procentowe $\mathrm{V}_{150-\mathrm{p}}, \mathrm{V}_{120-\mathrm{p}}$, najniższe w przypadku II schematu można wnioskować o korzystniejszych warunkach leczenia. Istotność statystyczną 
różnic wykazano jedynie między wartościami $\mathrm{V}_{120-p}(\mathrm{I}-70,5 \%$, II - 67,6\%, III - 68,7\%) z $\mathrm{p}=0,0264 \mathrm{w}$ teście K-W (rycina 10). Zastosowany dodatkowo test Dunn'a wykazał istotność zmian parametrów pomiędzy I i II schematem leczenia (tabela 16).

Rycina 10. Porównanie wartości parametru dla $\mathrm{V}_{120-\mathrm{p}} \mathrm{W}$ trzech schematach brachyterapii HDR.

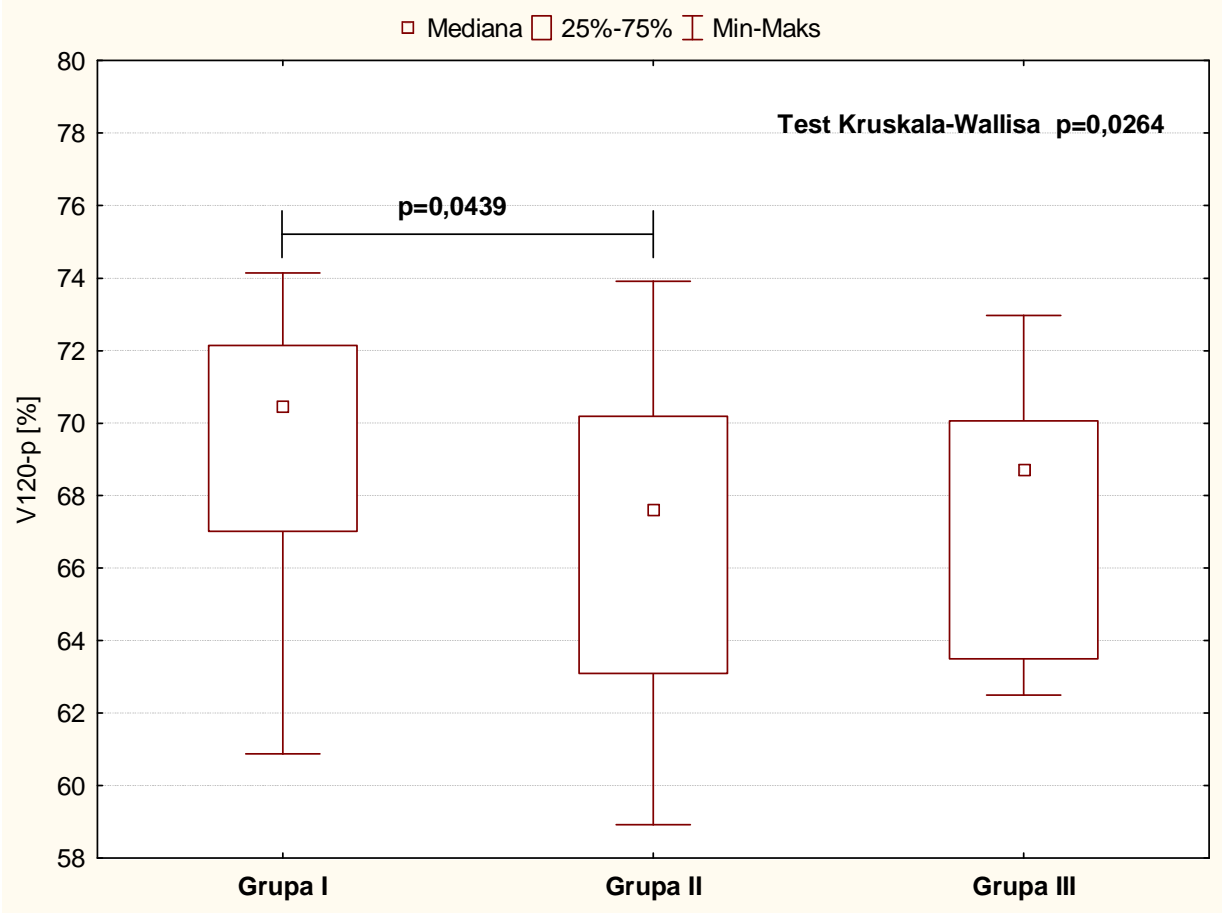

Tabela 16. Porównanie zmienności parametru $\mathrm{V}_{120-\mathrm{p}} \mathrm{W}$ trzech schematach brachyterapii HDR w teście Dunn'a.

\begin{tabular}{|c|c|c|c|}
\hline Porównanie schematów & Suma & Różnica & Wartość p \\
\hline I v II & $\begin{array}{c}\text { I - 38,49 } \\
\text { II }-25,22\end{array}$ & 13,27 & $<0,05$ \\
\hline II v III & II $-25,22$ & $-1,48$ & $>0,05$ \\
\hline III $-26,7$ & I $-38,49$ \\
III $-26,7$ & 11,79 & $>0,05$ \\
\hline
\end{tabular}

$\mathrm{Z}$ drugiej strony, ważniejsze parametry punktów dawek wysokich takie jak $\mathrm{D}_{\text {max-p }}, \mathrm{V}_{200-\mathrm{p}} \mathrm{a}$ ponadto $D_{\text {mean-p }}$ okazały się procentowo najwyższe w grupie II. Pozwalają one uznać parametry punktów gorących jako najmniej korzystne, porównując wszystkie schematy. Wartość $\mathrm{V}_{200-p}$ przekroczyła limit akceptacji planu (15,9\%) w schemacie brachyterapii 2 x 10 
Gy ( $\mathrm{p}=0,2795 \mathrm{w} \mathrm{K}-\mathrm{W})$, parametr $\mathrm{D}_{\text {max-p }}$, procentowo był wyraźnie wyższy i co najważniejsze jego zmiana była istotna statystycznie (I - 1066,5\%, II - 1812,2\%, III - 1078,2\%, p=0,0011 w K-W). Ponownie zastosowany test Dunn'a pokazał różnicę pomiędzy I i II oraz II i III schematem brachyterapii (tabela 17). Graficzne porównanie parametrów $\mathrm{D}_{\max -\mathrm{p}} \mathrm{w}$ trzech schematach przedstawiono na rycinie 11 .

Rycina 11. Porównanie wartości parametru dla $D_{\max -p} w$ trzech schematach brachyterapii HDR.

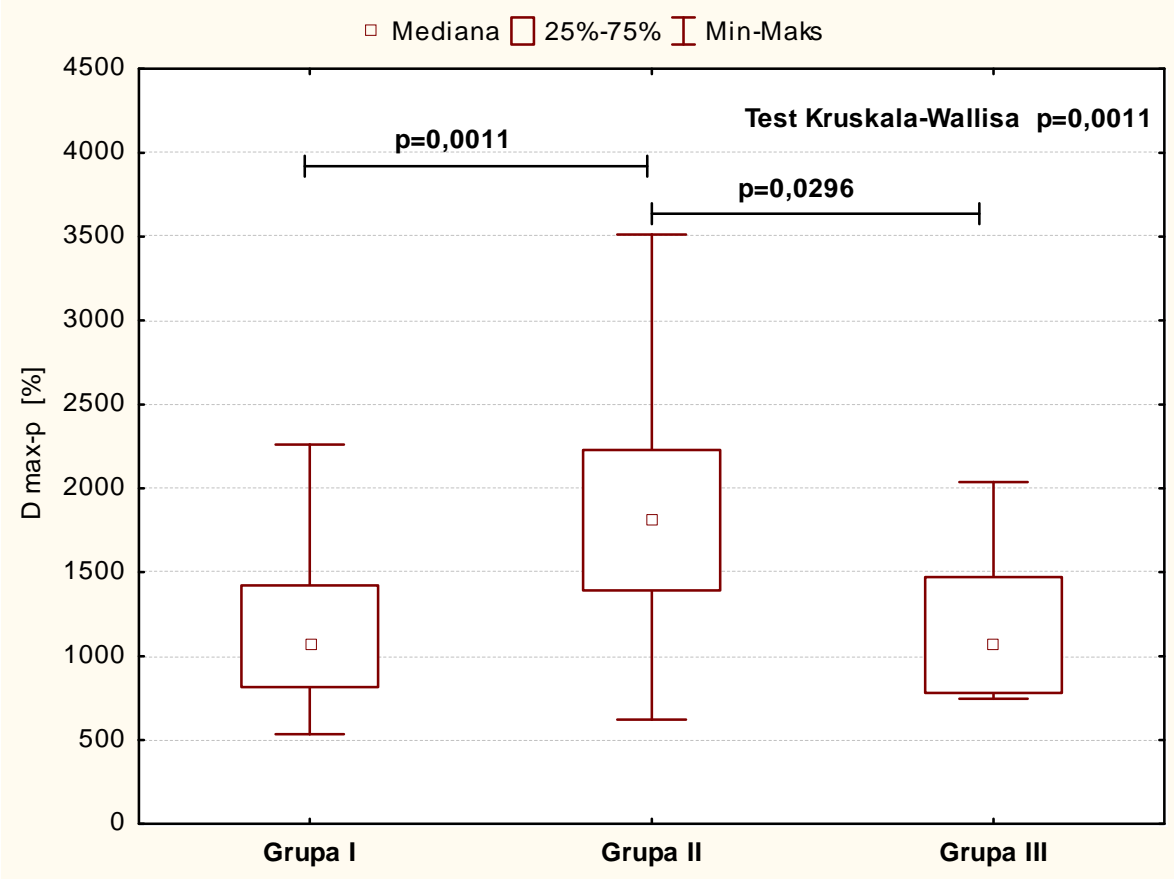

Tabela 17. Porównanie zmienności parametru $\mathrm{D}_{\text {max-p }} \mathrm{W}$ trzech schematach brachyterapii HDR w teście Dunn'a.

\begin{tabular}{|c|c|c|c|}
\hline Porównanie schematów & Suma & Różnica & Wartość p \\
\hline I v II & I $-27,65$ & $-19,3$ & $<0,05$ \\
\hline II $-46,95$ & II $-46,95$ & 19,25 & $<0,05$ \\
\hline I v III & III $-27,7$ & $-0,05$ & $>0,05$ \\
\hline
\end{tabular}

Parametry dawek w obrębie cewki moczowej wykazują wyraźny wzrost w grupie II, porównując schematy leczenia. Najwyższa wartość procentowa $\mathrm{D}_{10-\mathrm{u}}(123,5 \%)$ jeszcze nie 
różni się w sposób statystycznie istotny $(\mathrm{p}=0,2698)$ ale objętość dawki $100 \%\left(\mathrm{~V}_{100-u}\right)$ różni się istotnie (I - 46,1\%, II - 54,2\%, III - 49,3\% - test $\mathrm{K}-\mathrm{W}, \mathrm{p}=0,036)$. W teście Dunn'a ta różnica została potwierdzona pomiędzy parametrami w grupie I i II. Podobna sytuacja wystąpiła w przypadku porównań parametrów $\mathrm{D}_{\text {mean-u }}$ (II - 97,7\%, p=0,0052), $\mathrm{D}_{\text {min-u }}$ (II - 42,7\%, $\mathrm{p}=0,0027$ ). Porównanie $\mathrm{D}_{\text {min-u }}$ testem Dunn'a w cewce nie wykazało różnic między frakcjami II i III oraz I i III, natomiast dla wartości Dmean-u różnice stwierdzono jedynie między I i III. Porównanie średnich parametrów $\mathrm{D}_{\text {mean-u }}$ i $\mathrm{D}_{\text {min-u }}$, w trzech schematach przedstawiono na rycinach 12,13,14 wyniki porównań testu Dunn'a w tabelach 18,19,20.

Rycina 12. Porównanie wartości parametru dla $\mathrm{D}_{\text {mean-u }} \mathrm{W}$ trzech schematach brachyterapii HDR.

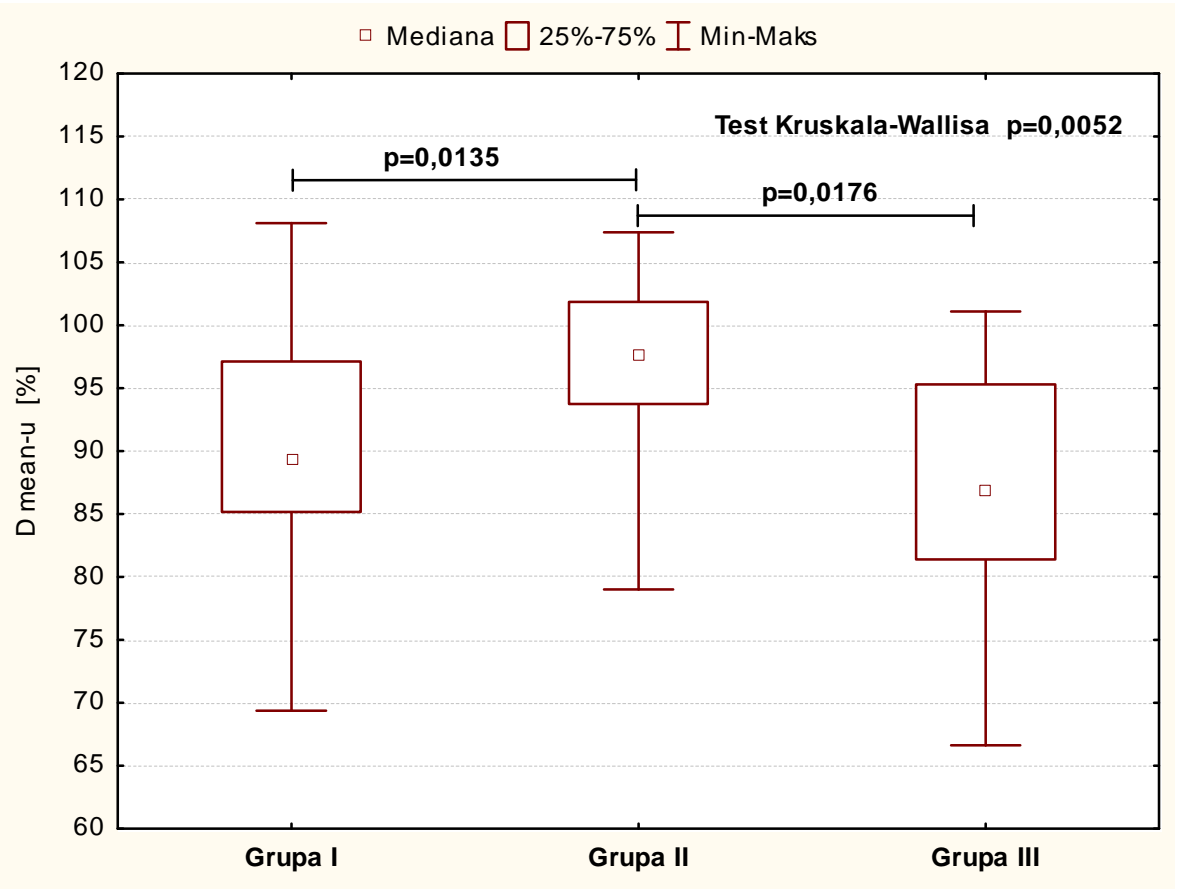

Tabela 18. Porównanie zmienności parametru $\mathrm{D}_{\text {mean-u }} \mathrm{W}$ trzech schematach brachyterapii HDR w teście Dunn'a.

\begin{tabular}{|c|c|c|c|}
\hline Porównanie schematów & Suma & Różnica & Wartość p \\
\hline I v II & $\begin{array}{l}\text { I }-29,51 \\
\text { II }-44,95\end{array}$ & $-15,44$ & $<0,05$ \\
\hline II v III & $\begin{array}{l}\text { II }-44,95 \\
\text { III }-24,4\end{array}$ & 20,55 & $<0,05$ \\
\hline I v III & $\begin{array}{l}\text { I }-29,51 \\
\text { III }-24,4\end{array}$ & 5,11 & $>0,05$ \\
\hline
\end{tabular}


Rycina 13. Porównanie wartości parametru dla $\mathrm{D}_{\text {min-u }} \mathrm{w}$ trzech schematach brachyterapii HDR.

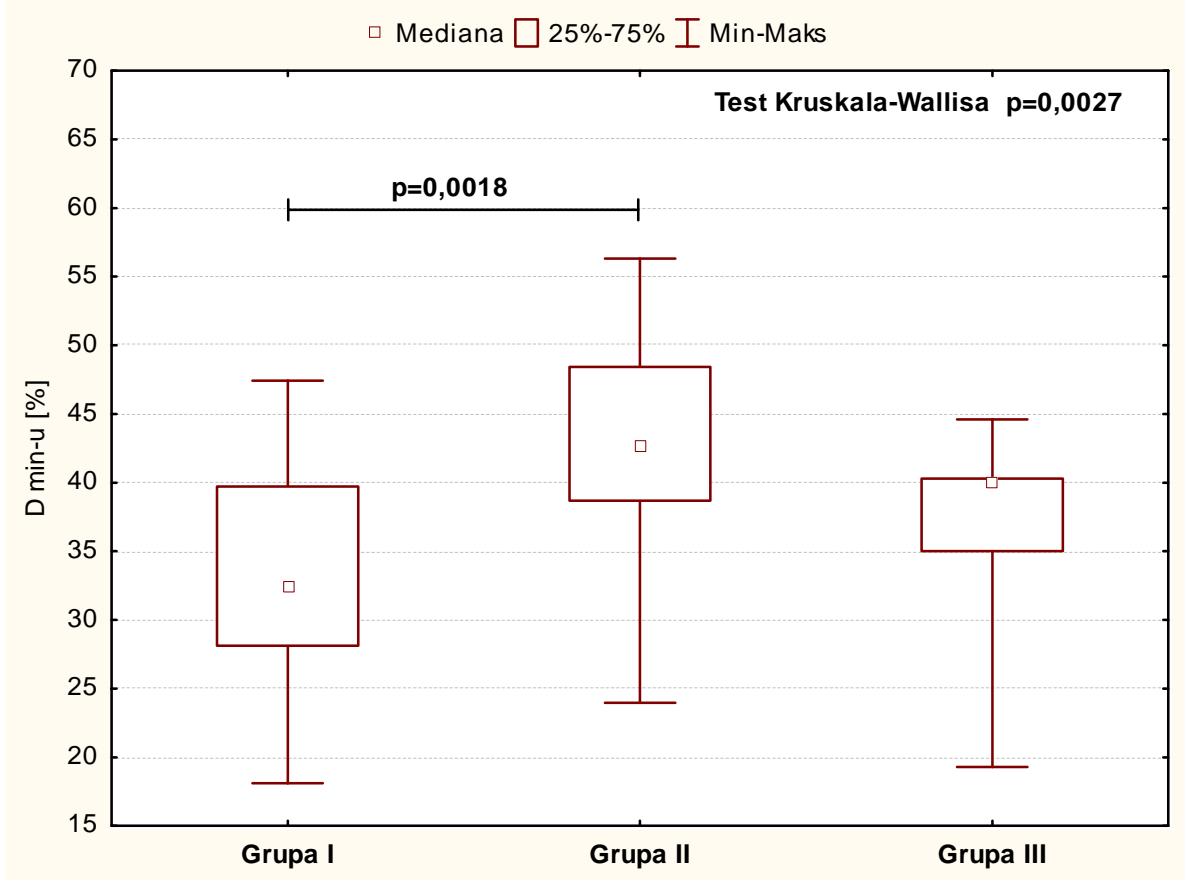

Tabela 19. Porównanie zmienności parametru $\mathrm{D}_{\text {min-u }} \mathrm{W}$ trzech schematach brachyterapii HDR w teście Dunn'a.

\begin{tabular}{|c|c|c|c|}
\hline Porównanie schematów & Suma & Różnica & Wartość p \\
\hline I v II & I $-26,65$ & $-18,63$ & $<0,05$ \\
\hline II $-45,28$ & II $-45,28$ & 10,88 & $>0,05$ \\
\hline II v III & III $-34,4$ & $-7,75$ & $>0,05$ \\
\hline
\end{tabular}


Rycina 14. Porównanie wartości parametru dla $\mathrm{V}_{100-\mathrm{u}} \mathrm{W}$ trzech schematach brachyterapii HDR.

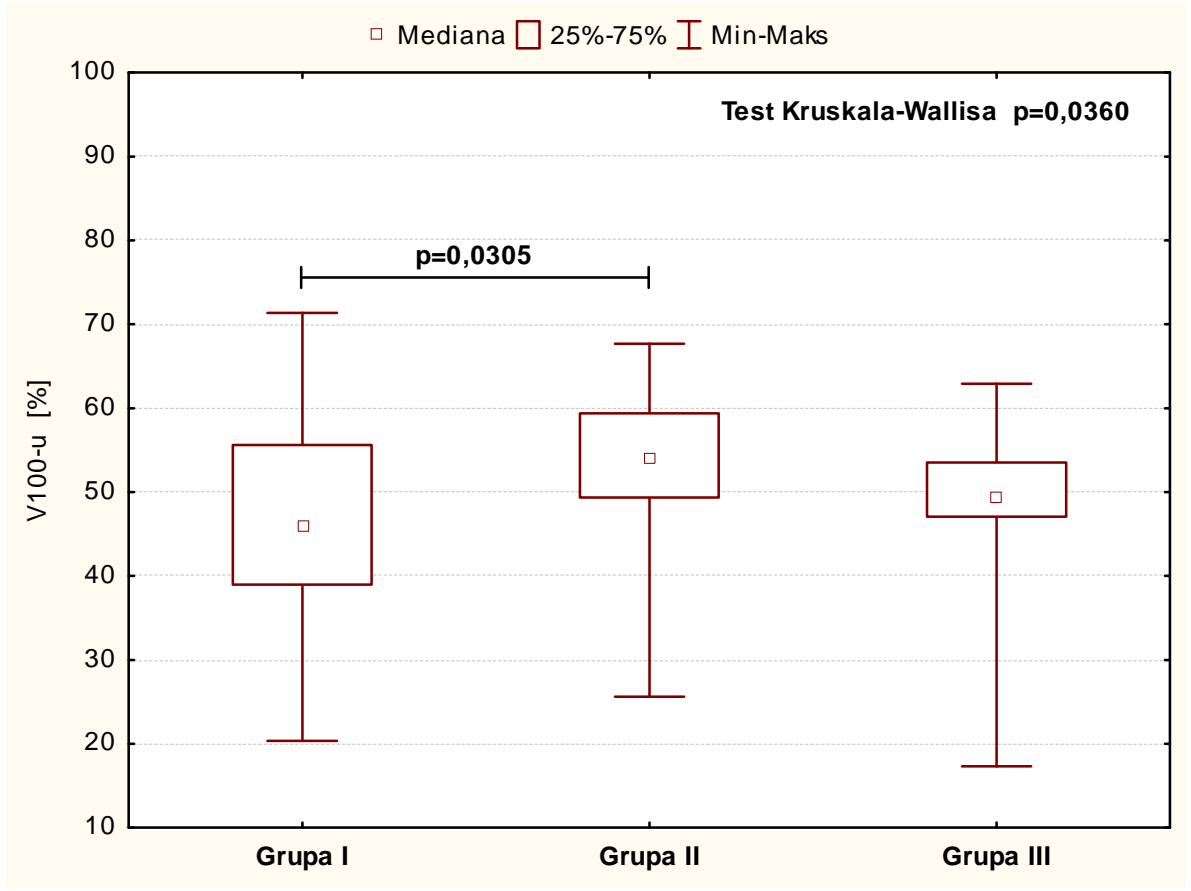

Tabela 20. Porównanie zmienności parametru $\mathrm{V}_{100-\mathrm{u}} \mathrm{W}$ trzech schematach brachyterapii HDR w teście Dunn'a.

\begin{tabular}{|c|c|c|c|}
\hline Porównanie schematów & Suma & Różnica & Wartość p \\
\hline I v II & I $-28,65$ & $-13,69$ & $<0,05$ \\
\hline II $-42,61$ & II $-42,61$ & 10,81 & $>0,05$ \\
\hline III $-31,8$ & I $-28,65$ & $-3,15$ & $>0,05$ \\
\hline
\end{tabular}

Dodatkowo parametr odchylenia standardowego wyników dawek $\left(\mathrm{SD}_{-\mathrm{u}}\right)$ okazał się najniższy w schemacie II wskazując na fakt, że wyższe dawki w tej grupie mogą być bardziej jednorodne w cewce moczowej. Porównanie statystyczne $\mathrm{SD}_{-u}$ było istotne w teście KruskalaWallisa ( $\mathrm{p}=0,0078)$, test Dunn'a zróżnicował wartości parametrów między I i II schematem (rycina 15 , tabela 21$)$. Pozostałe parametry z grupy 2 x 10 Gy, takie jak $\mathrm{V}_{\text {crit-u }}(20,2 \%), \mathrm{D}_{\text {max-u }}$ $(144,4 \%)$, porównując $\mathrm{z}$ pozostałymi schematami nie osiągnęły $\mathrm{w}$ teście $\mathrm{K}-\mathrm{W}$ istotności (odpowiednio: $\mathrm{p}=0,3646, \mathrm{p}=0,7246$ ). 
Rycina 15. Porównanie wartości parametru dla $\mathrm{SD}_{-\mathrm{u}} \mathrm{w}$ trzech schematach brachyterapii HDR.

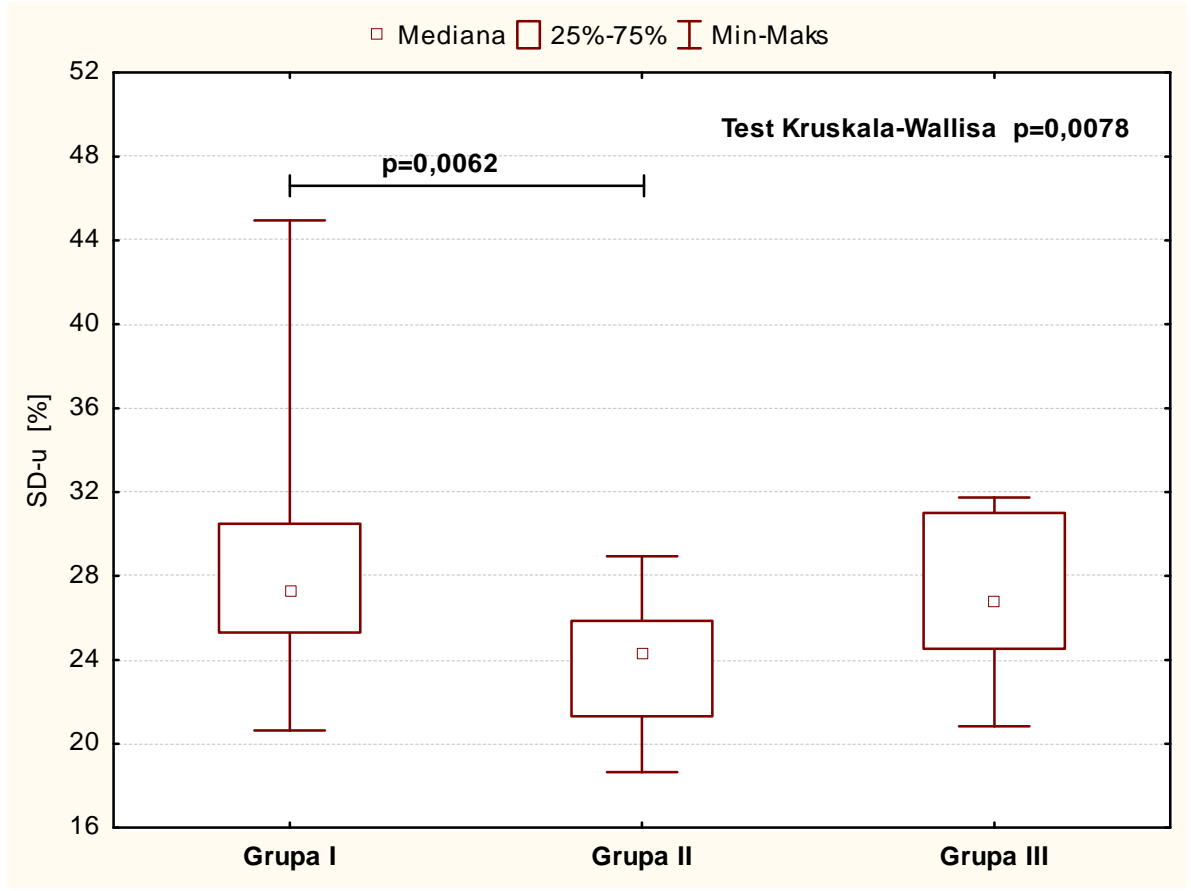

Tabela 21. Porównanie zmienności parametru $\mathrm{SD}_{-\mathrm{u}} \mathrm{W}$ trzech schematach brachyterapii HDR w teście Dunn'a.

\begin{tabular}{|c|c|c|c|}
\hline Porównanie schematów & Suma & Różnica & Wartość p \\
\hline I v II & I $-38,03$ & 16,75 & $<0,05$ \\
\hline II $-21,28$ & II $-21,28$ \\
III $-36,5$ & $-15,22$ & $>0,05$ \\
\hline I v III & I $-38,03$ & 1,53 & $>0,05$ \\
\hline
\end{tabular}

Dawki procentowe podane na ścianę odbytnicy okazały w każdym ze schematów leczenia podobne. Zastosowany test Kruskala-Wallisa nie wykazał istotności statystycznej w porównaniu parametrów objętości i dawki dla tego organu ryzyka. Analizując zmienność wartości procentowych zauważono, że wysokość dawki w obrębie odbytnicy była nieznacznie większa w obu grupach z wyższą dawką frakcyjną (I i III). Parametr $\mathrm{D}_{10-r}$ najwyższy w schemacie monoterapii HDR (III) $-66,1 \%$ (porównanie nie istotne $\mathrm{p}=0,5005$ ).

Najwyższa dla grupy III okazała się także wartość $\mathrm{D}_{\text {mean-r }}(47,9 \%, \mathrm{p}=0,2239)$. 
Dla powyższego schematu leczenia BRT-HDR zaobserwowano najwyższe $V_{\text {crit-r }}(0,2 \%$, $\mathrm{p}=0,2441)$ oraz dawkę minimalną $\mathrm{D}_{\text {min-r }}(25,6 \%, \mathrm{p}=0,2427)$. Brak wykazanych różnic $\mathrm{w}$ teście statystycznym K-W nie pozwala na wyodrębnienie schematu leczenia gdzie wartości parametrów planu leczenia są wyraźnie korzystniejsze od innych, pod kątem ochrony przedniej ściany odbytnicy.

Dawki biologiczne w tym rozdziale porównano testem Manna-Whitneya dla zmiennych niezależnych, pomiędzy grupami o podobnej wartości dawki frakcyjnej (I i III). Analizując tabele 9-11 zauważono w tych grupach podobne wysokości dawek podanych na objętość gruczołu krokowego, cewki moczowej czy odbytnicy. Zastosowany test porównawczy nie wykazał różnic istotnych statystycznie w przypadku żadnego parametru dawki schematów I i III. Najwyższe dawki maksymalne stwierdzono w grupie III (BED max-p$^{-} 1779$ Gy), dla porównania $\mathrm{BED}_{90-\mathrm{p}} \mathrm{w}$ grupie I wyniosło 1759,6 Gy. Parametr $\mathrm{BED}_{\text {mean-p }}$ był najwyższy w schemacie monoterapii - 256,1 Gy. Podobną zmienność parametrów wykazano w przypadku cewki moczowej, gdzie $\mathrm{BED}_{\text {max-u }}$ najwyższą wartość osiągnął również w grupie III (130,8 Gy), a BED ${ }_{\text {min-u }}-36$ Gy. Dla tego organu krytycznego dawka średnia BED $_{\text {mean-u }}$ była niższa dla schematu monoterapii HDR (78,3 Gy). Parametry dawek biologicznych w odbytnicy okazały się zróżnicowane: $\mathrm{BED}_{\text {max-r }}$ wyższy był w I schemacie $\left(76,3 \mathrm{~Gy}\right.$ ) natomiast $\mathrm{BED}_{10-\mathrm{r}}$

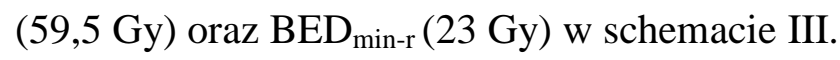

Pomimo obserwacji powyższych prawidłowości, nie wykazano zmienności dawek biologicznych pomiędzy schematami brachyterapii HDR o dawce frakcyjnej 15 Gy. Analizy statystyczne wartości objętości oraz dawek wyrażonych w procentach i grejach, w testach Kruskala-Wallisa oraz Manna-Whitneya przedstawiono w tabeli 14.

\subsection{Analiza zależności pomiędzy czynnikami prognostycznymi a wartościami} dawek i objętości planu leczenia.

Analizę statystyczną przeprowadzono, aby zidentyfikować czynniki prognostyczne, które mogą wpływać na parametry planu w trakcie brachyterapii, ułatwiając jednocześnie dobór pacjentów do odpowiednich schematów leczenia. Wśród tych czynników wybrano parametry wieku, stopnia zaawansowania klinicznego (TNM), złośliwości histologicznej wg. Gleasona, poziomu wyjściowego PSA (iPSA), objętości gruczołu oraz liczby użytych do leczenia aplikatorów igłowych. W zastosowanym teście statystycznym Spearmana użyto średnich 
Tabela 22. Wyniki analizy statystycznej testu korelacji Spearmana pomiędzy czynnikami prognostycznymi a wartościami dawek i objętości gruczołu krokowego. Poziom p<0,05 dla istotnego statystycznie współczynnika korelacji r zaznaczono kolorem czerwonym.

\begin{tabular}{|c|c|c|c|c|c|c|c|c|}
\hline & P. progt. & & $\begin{array}{c}\text { Wiek } \\
\text { (r) }\end{array}$ & $\begin{array}{c}\text { TNM } \\
(\mathbf{r})\end{array}$ & $\begin{array}{c}\text { Gleason } \\
\text { (r) }\end{array}$ & $\begin{array}{c}\text { iPSA } \\
(\mathbf{r})\end{array}$ & $\begin{array}{c}\text { Objętość } \\
\text { (r) }\end{array}$ & $\begin{array}{c}\text { Liczba igiel } \\
\text { (r) }\end{array}$ \\
\hline & D $90-p$ & I & $\begin{array}{l}-0,1980 \\
\end{array}$ & $-0,0191$ & 0,0983 & $-0,1021$ & 0,3524 & 0,4104 \\
\hline & & II & $-0,4509$ & 0,1962 & $-0,1768$ & 0,1414 & 0,5537 & 0,3682 \\
\hline & & III & -0.0793 & 0,1124 & 0,2126 & 0,2242 & $\underline{0,8146}$ & 0,5047 \\
\hline & BED $_{90-\mathrm{p}}$ & I & $-0,1977$ & $-0,0213$ & 0,0983 & $-0,1021$ & 0,3524 & 0,4104 \\
\hline & & II & $-0,4509$ & 0,1962 & $-0,1768$ & 0,1414 & $\underline{0,5537}$ & 0,3682 \\
\hline & & III & $-0,0793$ & 0,1124 & 0,2126 & 0,2242 & $\underline{0,8146}$ & 0,5047 \\
\hline & $V_{\text {200-p }}$ & I & $-0,1065$ & $-0,0100$ & 0,0008 & $-0,2035$ & $-0,2115$ & $-0,3358$ \\
\hline & & II & 0,1735 & $-0,2150$ & 0,2274 & -0.1971 & $-0,4029$ & $-0,4530$ \\
\hline & & III & 0,6220 & $-0,2550$ & $-0,2814$ & -0.2970 & -0.0182 & 0,2585 \\
\hline & $V_{150-p}$ & I & $-0,0960$ & 0,0924 & -0.1996 & -0.0142 & $-0,0209$ & $-0,0273$ \\
\hline & & II & $-0,1361$ & $-0,2796$ & $\underline{0,5583}$ & $-0,0196$ & 0,0806 & 0,0492 \\
\hline & & III & $\underline{-0,6707}$ & 0,2322 & 0,1626 & $-0,2000$ & 0,1824 & $\underline{0,6462}$ \\
\hline & $\mathbf{V}_{120-p}$ & I & $-0,2310$ & 0,2178 & $-0,2179$ & -0.0312 & $\underline{0,4327}$ & $\underline{0,3778}$ \\
\hline & & II & $-0,2868$ & $-0,0470$ & 0,3537 & 0.1785 & $\underline{0,5269}$ & 0,3986 \\
\hline II & & III & $\underline{-0,6768}$ & 0,5244 & 0,3814 & 0,1152 & 0,3526 & $\underline{0,7447}$ \\
\hline 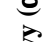 & $\mathrm{V}_{100-\mathrm{p}}$ & I & $-0,2151$ & 0,0137 & 0,0946 & -0.0377 & $\underline{0,3796}$ & $\underline{0,4632}$ \\
\hline 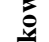 & & II & $\underline{-0,4831}$ & 0,1703 & $\underline{0,5583}$ & 0.2033 & $\underline{0,6219}$ & 0,4467 \\
\hline$\underline{ \pm}$ & & III & $-0,0732$ & 0,3970 & 0,4252 & 0,1394 & $\underline{0,7720}$ & $\underline{0,7509}$ \\
\hline ริ & $D_{\text {min-p }}$ & I & 0,0436 & 0,0088 & 0,0926 & -0.2205 & 0,1959 & 0,0878 \\
\hline$E_{0}$ & & II & $-0,4434$ & 0,2262 & $-0,3602$ & 0,1270 & $\underline{0,5349}$ & 0,3438 \\
\hline$\sum^{2}$ & & III & $-0,3781$ & -0.1348 & 0,2126 & $-0,0303$ & $\underline{0,6869}$ & 0,5785 \\
\hline 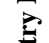 & BED $_{\text {min-p }}$ & $\mathbf{I}$ & 0,0436 & 0,0088 & 0,0926 & -0.2205 & 0,1959 & 0,0878 \\
\hline 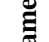 & & II & $-0,4052$ & 0.2361 & $-0,3878$ & 0,0960 & $\underline{0,5641}$ & 0,3557 \\
\hline$\approx$ & & III & $-0,3781$ & -0.1348 & 0,2126 & $-0,0303$ & $\underline{0,6869}$ & 0,5785 \\
\hline & $D_{\text {max }-\mathbf{p}}$ & I & 0,1045 & 0.0454 & 0,2298 & $-0,3087$ & $-0,0420$ & $-0,2393$ \\
\hline & & II & 0,5247 & -0.3348 & 0,1541 & $-0,2405$ & $-0,3595$ & $-0,3745$ \\
\hline & & III & $-0,2012$ & 0.4495 & 0,3064 & 0,0788 & -0.1033 & 0,1169 \\
\hline & BED $_{\text {max-p }}$ & I & 0,1045 & 0.0454 & 0,2298 & $-0,3087$ & $-0,0420$ & $-0,2393$ \\
\hline & & II & $\underline{0,5247}$ & -0.3348 & 0,1541 & $-0,2405$ & $-0,3595$ & $-0,3745$ \\
\hline & & III & $-0,2012$ & 0.4495 & 0,3064 & 0,0788 & -0.1033 & 0,1169 \\
\hline & $D_{\text {mean-p }}$ & I & $-0,0992$ & 0,0613 & 0,0489 & $-0,2779$ & -0.0873 & $-0,2299$ \\
\hline & & II & 0,3325 & -0.3265 & 0,3588 & $-0,1950$ & $-0,3316$ & $-0,3881$ \\
\hline & & III & $-0,5161$ & -0.1948 & 0,1188 & $-0,4788$ & 0,0122 & 0,5047 \\
\hline & BED $_{\text {mean-p }}$ & I & $-0,0937$ & 0,0613 & 0,0489 & $-0,2779$ & -0.0895 & $-0,2299$ \\
\hline & & II & 0,3325 & -0.3265 & 0,3588 & $-0,1950$ & $-0,3316$ & $-0,3881$ \\
\hline & & III & $-0,5610$ & -0.1948 & 0,0500 & $-0,5152$ & 0.0547 & 0,5601 \\
\hline & $\mathbf{S D}_{-\mathrm{p}}$ & I & 0,1041 & -0.1158 & 0,0608 & $-0,1692$ & $-0,2527$ & $\underline{-0,4310}$ \\
\hline & & II & 0,3553 & -0.1691 & 0,1011 & $-0,2425$ & $-0,4360$ & $-0,4226$ \\
\hline & & III & $-0,5244$ & 0,0150 & $-0,1313$ & $-0,3212$ & $-0,3587$ & $-0,0554$ \\
\hline
\end{tabular}


wartości parametrów optymalizacyjnych planu leczenia z jedną, dwoma i trzema frakcjami brachyterapii HDR, odpowiednio dla I, II, III grupy leczenia. Dla korelacji obliczono wartość współczynnika r, poziom p dla zależności statystycznie istotnych przyjęto jako $<0,05$. Wyniki przeprowadzonego testu korelacyjnego dla wszystkich parametrów, w trzech schematach leczenia przedstawiono w tabelach 22-24.

Tabela 23. Wyniki analizy statystycznej testu korelacji Spearmana pomiędzy czynnikami prognostycznymi a wartościami dawek i objętości w obrębie cewki moczowej. Poziom $\mathrm{p}<0,05$ dla istotnego statystycznie współczynnika korelacji $\mathrm{r}$ zaznaczono kolorem czerwonym.

\begin{tabular}{|c|c|c|c|c|c|c|c|c|}
\hline & P.pro & & $\begin{array}{c}\text { Wiek } \\
\text { (r) }\end{array}$ & $\begin{array}{c}\text { TNM } \\
\text { (r) }\end{array}$ & $\begin{array}{c}\text { Gleason } \\
(\mathbf{r})\end{array}$ & $\begin{array}{c}\text { iPSA } \\
(\mathbf{r})\end{array}$ & $\begin{array}{c}\text { Objętość } \\
\text { (r) }\end{array}$ & $\begin{array}{c}\text { Liczba igiel } \\
\text { (r) }\end{array}$ \\
\hline & $D_{10-u}$ & I & 0,2599 & 0,1471 & $-0,1152$ & 0,1414 & 0,0678 & $-0,2635$ \\
\hline & & II & 0,3262 & $-0,0670$ & 0,3107 & $-0,3664$ & $-0,2366$ & $-0,3808$ \\
\hline & & III & $-0,3963$ & 0,5169 & 0,0313 & 0,0545 & 0,1763 & 0,2216 \\
\hline & BED $_{\text {10-u }}$ & I & 0,2582 & 0,1449 & $-0,1177$ & 0,1379 & 0,0669 & $-0,2615$ \\
\hline & & II & 0,3262 & $-0,0670$ & 0,3107 & $-0,3664$ & $-0,2366$ & $-0,3808$ \\
\hline & & III & $-0,3963$ & 0,5169 & 0,0313 & 0,0545 & 0,1763 & 0,2216 \\
\hline & $V_{100-u}$ & $\mathbf{I}$ & 0,0239 & 0,1521 & $-0,1827$ & 0,0134 & 0,4923 & 0,0924 \\
\hline & & II & $-0,0904$ & 0,2514 & $-0,3562$ & $-0,4386$ & 0,2913 & 0,0073 \\
\hline$\pi$ & & III & 0,1890 & $\underline{0,8090}$ & 0,5002 & 0,6242 & 0,0547 & $-0,0492$ \\
\hline$\stackrel{n}{3}$ & $\mathbf{V}_{\text {crit-u }}$ & I & 0,1861 & 0,3125 & $-0,3071$ & 0,1204 & 0,4063 & $-0,0158$ \\
\hline e & & II & 0,0748 & 0,1398 & 0,1288 & -0.3829 & 0,0630 & $-0,1684$ \\
\hline 3 & & III & $-0,2134$ & 0,5993 & 0,0938 & 0.0182 & $-0,0365$ & 0,1292 \\
\hline న & $D_{\text {min-u }}$ & I & $-0,0260$ & $-0,1314$ & $-0,0904$ & 0,0231 & 0,2009 & 0,0175 \\
\hline อ르 & & II & 0,2057 & 0,0110 & $-0,3499$ & $\underline{-0,6140}$ & 0,3037 & $-0,1716$ \\
\hline$\sigma$ & & III & 0,4085 & 0,3596 & $-0,0063$ & 0,2970 & $-0,0608$ & $-0,3754$ \\
\hline 3 & BED $_{\text {min-u }}$ & I & $-0,0260$ & $-0,1314$ & $-0,0904$ & 0,0231 & 0,2009 & 0,0175 \\
\hline 8 & & II & 0,2110 & 0,0110 & $-0,3602$ & $-0,6257$ & 0,2941 & $-0,1790$ \\
\hline$\exists$ & & III & 0,4085 & 0,3596 & $-0,0063$ & 0,2970 & $-0,0608$ & $-0,3754$ \\
\hline อ & $D_{\text {max }-u}$ & I & 0,1920 & 0,1381 & 0,0546 & 0,1366 & $-0,1614$ & $-0,2437$ \\
\hline$B$ & & II & 0,4634 & $-0,1797$ & 0,3537 & $-0,3437$ & $\underline{-0,5072}$ & $\underline{-0,6099}$ \\
\hline$\Phi$ & & III & $-0,4024$ & $-0,0599$ & $-0,2439$ & $-0,2727$ & 0,0000 & 0,2216 \\
\hline 7 & BED $_{\text {max-u }}$ & I & 0,1920 & 0,1381 & 0,0546 & 0,1366 & $\begin{array}{l}-0,1614 \\
\end{array}$ & $-0,2437$ \\
\hline ש & & II & 0,4634 & $-0,1797$ & 0,3537 & $-0,3437$ & $\underline{-0,5072}$ & $\underline{-0,6099}$ \\
\hline & & III & $-0,4024$ & $-0,0599$ & $-0,2439$ & $-0,2727$ & 0,000 & 0,2216 \\
\hline & $D_{\text {mean-u }}$ & I & 0,0423 & 0,1338 & $-0,1274$ & 0,0526 & 0,4138 & 0,0445 \\
\hline & & II & 0.1455 & 0,0529 & $-0,2059$ & $\underline{-0,5521}$ & 0,2397 & $-0,1203$ \\
\hline & & III & 0,1463 & 0,4495 & 0,1313 & 0,3818 & $-0,2310$ & $-0,2646$ \\
\hline & BED mean-u & I & 0,0423 & 0,1338 & $-0,1274$ & 0,0526 & 0,4138 & 0,0445 \\
\hline & & II & 0.1455 & 0,0529 & $-0,2059$ & $\underline{-0,5521}$ & 0,2397 & $-0,1203$ \\
\hline & & III & 0,1463 & 0,4495 & 0,1313 & 0,3818 & $-0,2310$ & $-0,2646$ \\
\hline & $\mathbf{S D}_{-\mathrm{u}}$ & I & 0,1533 & 0,1895 & $-0,1640$ & $-0,0103$ & $-0,0910$ & $-0,2488$ \\
\hline & & II & $-0,1361$ & 0,0670 & 0,3790 & $\underline{0,5604}$ & $\underline{-0,4907}$ & $-0,0659$ \\
\hline & & III & $-0,2195$ & $-0,4644$ & $-0,1626$ & $-0,6242$ & $-0,0547$ & 0,2462 \\
\hline
\end{tabular}


Tabela 24.Wyniki analizy statystycznej testu korelacji Spearmana pomiędzy czynnikami prognostycznymi a wartościami dawek w obrębie odbytnicy. Poziom $\mathrm{p}<0,05$ dla istotnego statystycznie współczynnika korelacji r zaznaczono kolorem czerwonym.

\begin{tabular}{|c|c|c|c|c|c|c|c|c|}
\hline & P. propt. & & $\begin{array}{c}\text { Wiek } \\
\text { (r) }\end{array}$ & $\begin{array}{c}\text { TNM } \\
\text { (r) }\end{array}$ & $\begin{array}{c}\text { Gleason } \\
\text { (r) }\end{array}$ & $\begin{array}{c}\text { iPSA } \\
(\mathbf{r})\end{array}$ & $\begin{array}{c}\text { Objętość } \\
\text { (r) }\end{array}$ & $\begin{array}{c}\text { Liczba igieł } \\
\text { (r) }\end{array}$ \\
\hline & $D_{10-\mathrm{r}}$ & I & $-0,1109$ & 0,1079 & $\underline{-0,3773}$ & $-0,0544$ & 0,1880 & 0,0229 \\
\hline & & II & 0,0540 & 0,0258 & 0,0872 & $-0,3643$ & $\underline{0,5868}$ & 0,2417 \\
\hline & & III & $-0,4512$ & 0,2847 & 0,1813 & 0,1030 & $-0,1520$ & 0,1169 \\
\hline & BED $_{10-\mathrm{r}}$ & I & $-0,1109$ & 0,1079 & $-\underline{-0,3773}$ & $-0,0544$ & 0,1880 & 0,0229 \\
\hline & & II & 0,0540 & 0,0258 & 0,0872 & $-0,3643$ & $\underline{0,5868}$ & 0,2417 \\
\hline & & III & $-0,4512$ & 0,2847 & 0,1813 & 0,1030 & $-0,1520$ & 0,1169 \\
\hline & $V_{100-r}$ & I & 0,1239 & 0,1086 & $-0,0941$ & 0,1023 & $-0,0059$ & $-0,3896$ \\
\hline & & II & 0,0131 & $-0,0239$ & $-0,2906$ & $-0,3795$ & 0,4321 & 0,1895 \\
\hline & & III & $-0,5805$ & 0,0971 & 0,0810 & $-0,1366$ & $-0,4657$ & $-0,0173$ \\
\hline$\pi$ & $\mathbf{V}_{\text {crit-r }}$ & I & $-0,0072$ & 0,0770 & $-0,2710$ & $-0,0315$ & $-0,0736$ & $-0,1841$ \\
\hline$\stackrel{n}{=}$ & & II & 0,1333 & 0,1056 & $-0,4323$ & $\underline{-0,5496}$ & 0,4259 & 0,0412 \\
\hline 8 & & III & $-0,4985$ & 0,3006 & 0,2352 & $-0,0122$ & $-0,3079$ & 0,0772 \\
\hline שֶּ. & $\mathbf{D}_{\text {min-r }}$ & I & $-0,1405$ & 0,2850 & $-0,3774$ & $-0,0624$ & 0,2982 & 0,0457 \\
\hline & & II & $-0,0821$ & $-0,0270$ & 0,1238 & $-0,2239$ & $\underline{0,7293}$ & 0,2866 \\
\hline $\overrightarrow{0}$ & & III & $\underline{-0,6951}$ & 0,1948 & 0,1126 & 0,2848 & 0,6383 & 0,4801 \\
\hline$\underline{0}$ & BED $_{\text {min-r }}$ & I & $-0,1405$ & 0,2850 & $\underline{-0,3774}$ & $-0,0624$ & 0,2982 & 0,0457 \\
\hline$\frac{\pi}{8}$ & & II & $-0,0821$ & $-0,0270$ & 0,1238 & $-0,2239$ & $\underline{0,7293}$ & 0,2866 \\
\hline a & & III & $\underline{-0,6585}$ & 0,1948 & 0,1876 & 0,3576 & $\underline{0,6626}$ & 0,5662 \\
\hline 2 & $D_{\text {max-r }}$ & I & $-0,1156$ & 0,1688 & $-0,2776$ & 0,1226 & $-0,0203$ & $-0,2156$ \\
\hline$\stackrel{g}{g}$ & & II & 0,3408 & $-0,1398$ & $-0,1756$ & $-0,5604$ & 0,4277 & $-0,0282$ \\
\hline త్ర & & III & $-0,2622$ & 0,1798 & 0,2814 & 0,3091 & 0,0061 & 0,3200 \\
\hline ت & BED $_{\text {max-r }}$ & I & $-0,1156$ & 0,1688 & $-0,2776$ & 0,1226 & $-0,0203$ & $-0,2156$ \\
\hline & & II & 0,3408 & $-0,1398$ & $-0,1756$ & $-0,5604$ & 0,4277 & $-0,0282$ \\
\hline & & III & $-0,2622$ & 0,1798 & 0,2814 & 0,3091 & 0,0061 & 0,3200 \\
\hline & $D_{\text {mean-r }}$ & I & $-0,1550$ & 0,1764 & $\underline{-0,3795}$ & $-0,0881$ & 0,2671 & 0,0704 \\
\hline & & II & 0,0094 & 0,0458 & 0,0164 & $-0,2714$ & $\underline{0,7200}$ & 0,3002 \\
\hline & & III & $-0,4939$ & 0,4869 & 0,2939 & 0,3939 & 0,3526 & 0,4677 \\
\hline & BED mean-r $_{\text {m }}$ & I & $-0,1550$ & 0,1764 & $-0,3795$ & $-0,0881$ & 0,2671 & 0,0704 \\
\hline & & II & 0,0094 & 0,0458 & 0,0164 & $-0,2714$ & $\underline{0,7200}$ & 0,3002 \\
\hline & & III & $-0,4939$ & 0,4869 & 0,2939 & 0,3939 & 0,3526 & 0,4677 \\
\hline & SD-r & I & $-0,0345$ & $-0,0334$ & $-0,1429$ & 0,0958 & $-0,2151$ & $-0,2827$ \\
\hline & & II & 0,4675 & -0.0540 & $-0,1983$ & $\underline{-0,5129}$ & 0,2076 & $-0,0554$ \\
\hline & & III & $-0,0305$ & $-0,0749$ & 0,1813 & $-0,3455$ & $-0,4559$ & $-0,1908$ \\
\hline
\end{tabular}




\subsubsection{Zależności parametrów prognostycznych i wartości dawek oraz objętości w grupie I.}

Wykazano zależność statystyczną w teście Spearmana, pomiędzy stopniem złośliwości wg. Gleasona a parametrami dawek w obrębie odbytnicy. Wartości parametru $\mathrm{D}_{10-\mathrm{r}}(\mathrm{r}=-0,3773$, $\mathrm{p}=0,0233), \mathrm{BED}_{10-\mathrm{r}}(\mathrm{r}=-0,3773, \mathrm{p}=0,0233), \mathrm{D}_{\text {min-r }}(\mathrm{r}=-0,3774, \mathrm{p}=0,0233), \mathrm{BED}_{\text {min- } \mathrm{r}}$ $(\mathrm{r}=-0,3774, \mathrm{p}=0,0233), \mathrm{D}_{\text {mean-r }}(\mathrm{r}=-0,3794, \mathrm{p}=0,0225)$ oraz $\mathrm{BED}_{\text {mean-r }}(\mathrm{r}=-0,3794, \mathrm{p}=0,0225)$ okazały się odwrotnie proporcjonalne do wartości stopnia zróżnicowania komórkowego guza nowotworowego. $\mathrm{W}$ tej grupie wykazano także zależność statystyczną $\mathrm{w}$ przypadku parametru objętości gruczołu, a jego wartość była istotna dla parametrów $\mathrm{D}_{90-\mathrm{p}}(\mathrm{r}=0,3524$, $\mathrm{p}=0,0324), \mathrm{BED}_{90-\mathrm{p}}(\mathrm{r}=0,3524, \mathrm{p}=0,0324), \mathrm{V}_{100-\mathrm{p}}(\mathrm{r}=-0,3796, \mathrm{p}=0,0205)$ oraz $\mathrm{V}_{120-\mathrm{p}}(\mathrm{r}=0,4327$, $\mathrm{p}=0,0075)$. Objętość gruczołu krokowego przed leczeniem wpływała ponadto na parametry cewki moczowej takie jak: $\mathrm{V}_{100-u}(\mathrm{r}=0,4923, \mathrm{p}=0,002), \mathrm{V}_{\text {crit-u }}(\mathrm{r}=0,4063, \mathrm{p}=0,0126), \mathrm{D}_{\text {mean-u }}$ $(\mathrm{r}=0,4138, \mathrm{p}=0,0109)$ i BEDmean-u $(\mathrm{r}=0,4138, \mathrm{p}=0,0109)$. Zależności testu Spearmana w obu przypadkach były wprost proporcjonalne. Dla tego schematu brachyterapii nie stwierdzono zależności objętości gruczołu i wartości dawek w obrębie odbytnicy. Istotność statystyczną zaobserwowano pomiędzy liczbą zastosowanych aplikatorów igłowych a parametrami odpowiedzialnymi zarówno za prawidłowy rozkład dawki jak i za punkty wysokiej dawki. Parametry $\mathrm{D}_{90-\mathrm{p}}(\mathrm{r}=0,4104, \mathrm{p}=0,0116), \mathrm{BED}_{90-\mathrm{p}}(\mathrm{r}=0,4104, \mathrm{p}=0,0116), \mathrm{V}_{120-\mathrm{p}}$ $(\mathrm{r}=0,3778, \mathrm{p}=0,0211), \mathrm{V}_{100-\mathrm{p}}(\mathrm{r}=0,4632, \mathrm{p}=0,0039)$ były wprost proporcjonalne a $\mathrm{V}_{200-\mathrm{p}}(\mathrm{r}=-$ $0,3358, \mathrm{p}=0,0421)$ i $\mathrm{SD}_{-\mathrm{p}}(\mathrm{r}=-0,431 \mathrm{p}=0,0071)$ odwrotnie proporcjonalne. W uzyskanych wynikach zwrócono uwagę na istotną, odwrotnie proporcjonalną zależność między liczbą igieł a parametrem dawki $100 \%$ dla odbytnicy $\left(\mathrm{V}_{100-\mathrm{r}}, \mathrm{r}=-0,3896, \mathrm{p}=0,0172\right)$, jedyna, znalezioną dla tego organu ryzyka. W tej grupie (jedna frakcja brachyterapii HDR) nie znaleziono wpływu takich czynników prognostycznych jak wiek, stopień TNM oraz poziom PSA na wartości parametrów planu leczenia.

\subsubsection{Zależności parametrów prognostycznych i wartości dawek oraz objętości} w grupie II.

Jedynym czynnikiem prognostycznym, który w tym schemacie okazał się nie istotny dla planu leczenia był stopień zaawansowania klinicznego (TNM). W grupie niższej dawki frakcyjnej wykazano natomiast znamienną statystycznie zależność między wiekiem 
pacjentów a parametrami dla gruczołu krokowego: $\mathrm{V}_{100-\mathrm{p}}(\mathrm{r}=-0,4831, \mathrm{p}=0,0423), \mathrm{D}_{\max -\mathrm{p}}$ $(\mathrm{r}=0,5247, \mathrm{p}=0,0254)$ oraz $\mathrm{BED}_{\max -\mathrm{p}}(\mathrm{r}=0,5247, \mathrm{p}=0,0254)$. Stopień zróżnicowania komórkowego wg. Gleasona także okazał się być istotny dla $\mathrm{V}_{100-\mathrm{p}}(\mathrm{r}=0,5583$, p=0,0198) w tej grupie chorych. Wartość iPSA była odwrotnie proporcjonalna $\mathrm{w}$ teście korelacyjnym dla parametrów cewki moczowej: $\mathrm{D}_{\text {min-u }}(\mathrm{r}=-0,614, \mathrm{p}=0,0067), \mathrm{BED}_{\text {min-u }}(\mathrm{r}=-0,6257, \mathrm{p}=0,0055)$. $\mathrm{D}_{\text {mean-u }}(\mathrm{r}=-0,5521, \mathrm{p}=0,0175), \mathrm{BED}_{\text {mean-u }}(\mathrm{r}=-0,5521, \mathrm{p}=0,0175)$ a także odbytnicy: $\mathrm{D}_{\text {max-r }}(\mathrm{r}=-$

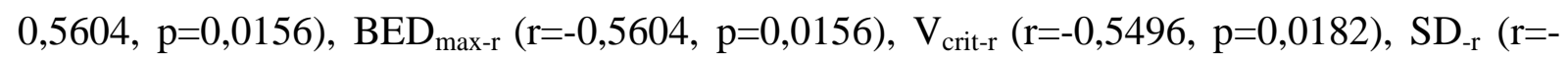
0,5129, $\mathrm{p}=0,0295)$. Wartość iPSA okazała się bez znaczenia dla objętości dawek w obrębie gruczołu krokowego. Parametrem prognostycznym najsilniej wpływającym w tej grupie na wartości planu leczenia była objętość gruczołu przed leczeniem. Zaobserwowano wpływ tego parametru zarówno na dawki gruczołu krokowego - $\mathrm{D}_{90-\mathrm{p}}(\mathrm{r}=0,5537, \mathrm{p}=0,0171), \mathrm{BED}_{90-\mathrm{p}}$ $(\mathrm{r}=0,5537, \mathrm{p}=0,0171), \mathrm{V}_{120-\mathrm{p}}(\mathrm{r}=0,5269, \mathrm{p}=0,0247), \mathrm{V}_{100-\mathrm{p}}(\mathrm{r}=0,6219, \mathrm{p}=0,0059), \mathrm{D}_{\text {min- }} \mathrm{p}$ $(\mathrm{r}=0,5349, \mathrm{p}=0,0222), \mathrm{BED}_{\min -\mathrm{p}}(\mathrm{r}=0,5641, \mathrm{p}=0,0148)$, cewki moczowej $-\mathrm{D}_{\max -\mathrm{u}}(\mathrm{r}=-0,5072$, $\mathrm{p}=0,0317), \mathrm{BED}_{\max -\mathrm{u}}(\mathrm{r}=-0,5072, \mathrm{p}=0,0317), \mathrm{SD}_{-\mathrm{u}}(\mathrm{r}=-0,4907, \mathrm{p}=0,0387)$, jak i odbytnicy $\mathrm{D}_{10-\mathrm{r}}(\mathrm{r}=0,5868, \mathrm{p}=0,0105), \mathrm{BED}_{10-\mathrm{r}}(\mathrm{r}=0,5868, \mathrm{p}=0,0105), \mathrm{D}_{\text {min-r }}(\mathrm{r}=0,7293, \mathrm{p}=0,0006)$, $\operatorname{BED}_{\text {min-r }}(r=0,7293, p=0,0006), D_{\text {mean-r }}(r=0,720 . p=0,0008), B_{\text {mean-r }}(r=0,720, p=0,0008)$. Powyższe korelacje testu Spearmana były wprost proporcjonalne dla parametrów gruczołu krokowego i odbytnicy, odwrotnie proporcjonalne dla cewki moczowej. Umiarkowanie ważnym czynnikiem prognostycznym w tej grupie okazała się liczba użytych aplikatorów igłowych. Wykazano odwrotnie proporcjonalną korelację pomiędzy liczbą igieł a $\mathrm{D}_{\max -\mathrm{u}} \mathrm{W}$ obrębie cewki moczowej ( $\mathrm{r}=-0,6099, \mathrm{p}=0,0072)$ i $\mathrm{BED}_{\max -\mathrm{u}}(\mathrm{r}=-0,6099, \mathrm{p}=0,0072)$ a nie zaobserwowano wpływu tego czynnika na wysokość dawek w gruczole krokowym i odbytnicy.

\subsubsection{Zależności parametrów prognostycznych i wartości dawek oraz objętości W grupie III.}

W grupie monoterapii HDR zwrócono uwagę na istnienie zależności statystycznej pomiędzy wiekiem pacjentów a parametrami dla gruczołu krokowego i odbytnicy. Wzrost wieku pacjentów był powiązany z obniżaniem objętości punktów wysokiej dawki: $\mathrm{V}_{150-p}(\mathrm{r}=-0,6707$, $\mathrm{p}=0,0338), \mathrm{V}_{120-\mathrm{p}}(\mathrm{r}=-0,6768, \mathrm{p}=0,0316) \mathrm{w}$ obrębie gruczołu krokowego. Zanotowano także odwrotnie proporcjonalną zależność miedzy wiekiem a wartością dawki minimalnej dla odbytnicy: $\mathrm{D}_{\text {min-r }}(\mathrm{r}=-0,6951, \mathrm{p}=0,0256)$ oraz $\mathrm{BED}_{\text {min-r }}(\mathrm{r}=-0,6585, \mathrm{p}=0,0384)$. Duży wpływ na 
parametry planu leczenia ponownie wykazano w przypadku objętości gruczołu krokowego. Wprost proporcjonalne korelacje zaobserwowano dla parametrów odpowiedzialnych za prawidłowe deponowanie dawki w obrębie targetu oraz za wartości dawek punktów niedopromienionych. Wraz ze wzrostem objętości zwiększały się wartości parametrów: $\mathrm{D}_{90-\mathrm{p}}$ $(\mathrm{r}=0,8146, \mathrm{p}=0,0041), \mathrm{BED}_{90-\mathrm{p}}(\mathrm{r}=0,8146, \mathrm{p}=0,0041), \mathrm{V}_{100-\mathrm{p}}(\mathrm{r}=0,7720, \mathrm{p}=0,0089)$ oraz $\mathrm{D}_{\text {min-p }}$ $(\mathrm{r}=0,6869, \mathrm{p}=0,0282), \mathrm{BED}_{\text {min-p }}(\mathrm{r}=0,6869, \mathrm{p}=0,0282)$. Większa objętość gruczołu krokowego była związana ze wzrostem dawki minimalnej w odbytnicy $\left(D_{\text {min-r }}, r=0,6383, p=0,0470\right.$ oraz $\left.\mathrm{BED}_{\text {min-r }}, \mathrm{r}=0,6626, \mathrm{p}=0,0368\right)$. Wpływ liczby aplikatorów igłowych ograniczył się w tym schemacie leczenia do korelacji wprost proporcjonalnej dla parametrów objętościowych gruczołu krokowego: $\mathrm{V}_{150-\mathrm{p}}(\mathrm{r}=0,6462, \mathrm{p}=0,0435), \mathrm{V}_{120-\mathrm{p}}(\mathrm{r}=0,7447, \mathrm{p}=0,0135)$ i $\mathrm{V}_{100-\mathrm{p}}$ $(\mathrm{r}=0,7509, \mathrm{p}=0,0123)$ i pozostał bez wpływu na parametry optymalizacyjne cewki moczowej i odbytnicy. Ostatnim czynnikiem prognostycznym gdzie wykazano istotną statystycznie korelację był stopień zaawansowania TNM i jego wpływ na objętość dawki 100\% w cewce moczowej $(r=0,8090, p=0,0046)$.

\section{Omówienie wyników i dyskusja.}

Wcześnie zaawansowany rak gruczołu krokowego jest nowotworem o stosunkowo dużej wyleczalności, niezależnie od rodzaju zastosowanego leczenia operacyjnego lub zachowawczego. Brachyterapia HDR w leczeniu skojarzonym raka gruczołu krokowego wykorzystywana jest przede wszystkim jako miejscowe podwyższenie dawki, po kursie teleradioterapii (ang. boost). W ostatnich latach uznanie zyskuje także samodzielna brachyterapia HDR w leczeniu pacjentów z grupy niskiego ryzyka (monoterapia HDR). Niezależnie od sposobu zastosowania brachyterapii, HDR-BRT w leczeniu raka gruczołu krokowego doskonale wpisuje się w model radiobiologiczny hipofrakcjonowania dawki, korzystny dla nowotworów o niskim współczynniku $\alpha / \beta$. Przy zastosowaniu tak wysokich dawek frakcyjnych jak 15 Gy w monoterapii szczególnie ważna jest kontrola wartości dawek, jakie otrzymują gruczoł krokowy (cel napromieniania) oraz narządy okoliczne. Wysokie, ponadnormatywne dawki w obrębie gruczołu, cewki moczowej, odbytnicy mogą skutkować późnymi, nieodwracalnymi odczynami popromiennymi, niwelując poważnie zysk terapeutyczny. Z drugiej strony obniżenie dawki w płacie obwodowym gruczołu krokowego, może skutkować nieodopromienieniem i niewyleczeniem pacjenta z nowotworu złośliwego, potencjalnie dającego przerzuty odległe. 
Niniejsza praca jest próbą analizy rozkładu dawek biologicznych w leczeniu skojarzonym oraz monoterapii, analizą zmian w nich zachodzących $\mathrm{z}$ frakcji na frakcję oraz wpływu czynników prognostycznych na otrzymane parametry planu leczenia. W światowej literaturze znajdziemy prace porównujące parametry dawki i objętości planu leczenia dla brachyterapii HDR oraz LDR [63]. Wiele uwagi poświęca się na temat wpływu objętości gruczołu oraz liczby użytych igieł $\mathrm{w}$ brachyterapii HDR na odległe wyniki leczenia oraz możliwe, towarzyszące powikłania $[64,65]$. Brak jest natomiast danych porównujących parametry planu leczenia w brachyterapii HDR oraz związku wybranych czynników prognostycznych w raku gruczołu krokowego z rozkładami dawek uzyskanych w obszarze leczonym i zdrowych narządach.

W przeprowadzonej analizie parametrów dawek i objętości nie zauważono istotnej statystycznie zmienności w schematach brachyterapii HDR złożonej z dwóch frakcji (II grupa) czy trzech frakcji leczenia (III grupa). Może to świadczyć o dość korzystnych parametrach uzyskanych we wstępnych frakcjach leczenia, które wymagają tylko nieznacznej korekty we frakcjach końcowych. W grupie o niższej dawce frakcyjnej ( 2 x 10 Gy) parametry odpowiadające za deponowanie dawki w obrębie targetu okazały się suboptymalne $\left(\mathrm{D}_{90-\mathrm{p}}\right.$ : $\left.88,26 \%, V_{100-p}: 82,4 \%\right)$ z obecnością punktów wysokiej dawki nieznacznie powyżej normy $\left(\mathrm{V}_{200-p}: 16,1 \%\right)$. Akceptacja planu wynikała $\mathrm{z}$ faktu przekroczenia ograniczeń w niewielkim stopniu, niższej dawki podanej z teleradioterapii (46 Gy) oraz niższej dawki frakcyjnej brachyterapii HDR (10 Gy). Duży wpływ na otrzymane wyniki mógł mieć ponadto stan doświadczenia personelu (do analizy włączeni zostali chorzy tuż po wprowadzeniu metody). W tej grupie ponadto korzystnie przedstawiały się parametry objętości i dawki cewki moczowej. Zauważono jednak ponadnormatywną dawkę maksymalną (obliczony dla pierwszej frakcji $\mathrm{BED}_{\text {max-r }}$ rzędu 41,1 Gy), przy prawidłowej dawce w $10 \%$ objętości $\left(\mathrm{BED}_{10-}\right.$ r: 27,1 Gy) w obrębie przedniej ściany odbytnicy. Przeprowadzający brachyterapię radioterapeuci starali się wyraźnie zmniejszyć dawkę maksymalną w tym narządzie krytycznym z dobrym efektem (BED $\mathrm{Bax}_{\text {-r }}$ drugiej frakcji: 37,6 Gy). Konsekwencją tego działania była niekorzystna, ale nieistotna statystycznie zmiana parametrów $\mathrm{D}_{10-\mathrm{r}}$, $\mathrm{BED}_{10-\mathrm{r}}$, $\mathrm{D}_{\text {mean-r }}, \mathrm{BED}_{\text {mean-r }}$ ) dla odbytnicy. Poprawę parametrów zauważono w obrębie cewki moczowej $\left(\mathrm{V}_{100-\mathrm{u}}, \mathrm{D}_{\max -\mathrm{u}}, \mathrm{BED}_{\text {max-u}}, \mathrm{D}_{\text {mean-u}}, \mathrm{BED}_{\text {mean-u }}\right)$. Kosztem ochrony odbytnicy zwiększeniu uległy dawki w punktach wysokiej dawki, natomiast dawka podana na 90\% objętości gruczołu krokowego praktycznie nie zmieniła się.

Problem korelacji pomiędzy parametrami planu leczenia a stopniem odczynów popromiennych układu pokarmowego i moczowego podniosło w swoich publikacjach szereg 
autorów. Kalakota wraz ze współpracownikami zauważył, że skojarzona radioterapia i brachyterapia raka gruczołu krokowego obciążona jest wyższym ryzykiem wystapienia odczynu popromiennego odbytnicy [66]. W okresie obserwacji 41 miesięcy, powikłania popromienne drugiego stopnia pojawiły się u około 10\% mężczyzn. Przeprowadzona analiza korelacji pomiędzy parametrami DVH a ryzykiem późnego odczynu popromiennego drugiego stopnia wykazała istotność statystyczną w przypadku $\mathrm{V}_{100-r}$. U 33\% pacjentów rozwinęły się objawy toksyczności późnej w przypadku, gdy objętość dawki $100 \%$ wynosiła $>0,05 \mathrm{~cm}^{3} \mathrm{w}$ 4-letniej obserwacji. Objętość $<0,05 \mathrm{~cm}^{3}$ dla parametru $\mathrm{V}_{100-\mathrm{r}}$ takich korelacji $\mathrm{w}$ obrębie odbytnicy nie wykazała [66]. W analizie zmian wartości dawek u pacjentów Zakładu Brachyterapii w II grupie, to właśnie $\mathrm{V}_{100-\mathrm{r}}$ okazał się parametrem najbardziej zmieniającym się z frakcji na frakcję, co może mieć znaczenie dla rozwoju powikłań w odbytnicy. Poza objętością dawki 100\% potencjalne znaczenie mają także dawki punktów gorących na powierzchni $0,1 \mathrm{~cm}^{3}$. W pracy Kalakoty zaznaczono jednak znaczenie tych korelacji jedynie w przypadku leczenia skojarzonego z EBRT. Autor wysunął ponadto hipotezę, że ryzyko śmiertelności po leczeniu brachyterapią może być zminimalizowane poprzez restrykcyjne zachowanie zasad akceptacji planu na podstawie DVH [66]. W innej publikacji Ghadjar

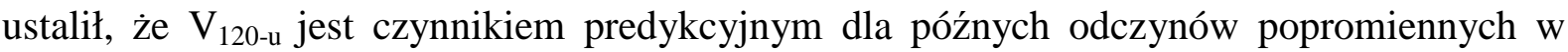
obrębie cewki moczowej w leczeniu skojarzonym BRT-HDR z IMRT [67]. Powikłania późne trzeciego i czwartego stopnia, zaobserwowane po brachyterapii u chorych wyniosły odpowiednio w 10,9\% i 1,6\%. Pinkawa wraz ze współpracownikami określił wpływ podanych dawek w obrębie narządów krytycznych na śmiertelność pacjentów w leczeniu raka gruczołu krokowego [68]. W tej grupie 50,4 Gy podawano z teleradioterapii na okolicę gruczołu a następnie brachyterapię HDR w dwóch frakcjach - 2 x 9 Gy. W wyniku korelacji statystycznej ustalono ryzyko śmiertelności z powodu powikłań dla dawki podanej na $1 \%$ powierzchni cewki moczowej i odbytnicy (D1). Aby zmniejszyć częstotliwość powikłań zagrażających życiu, D1 dla cewki powinien być niższy od 15 Gy a dla odbytnicy wynosić poniżej 6 Gy [68]. Wykazano ponadto zwiększoną tolerancję leczenia w przypadkach dłuższego czasu trwania EBRT, większej objętości gruczołu krokowego i liczby aplikatorów igłowych użytych w brachyterapii. W świetle powyższych rozważań nie dziwi zatem fakt, że w analizowanych przypadkach starano się zmniejszyć dawkę w obrębie odbytnicy, pomimo niskiej dawki frakcyjnej zastosowanego leczenia.

Porównując wartości parametrów dla grupy III (monoterapia HDR) przeważnie nie obserwowano zmian istotnych statystycznie. Grupa chorych z niskiej grupy ryzyka, o dobrym rokowaniu, otrzymała wysokie dawki frakcyjne (15 Gy) będąc w większym stopniu 
potencjalnie narażona na skutki obecności punktów wysokiej dawki. W pierwszych dwóch frakcjach monoterapii HDR parametry w obrębie gruczołu krokowego utrzymywały się w granicach akceptacji planu leczenia. Wartości $\mathrm{D}_{90-\mathrm{p}}$ oraz $\mathrm{BED}_{90-\mathrm{p}} \mathrm{w}$ dwóch pierwszych frakcjach wynosiły odpowiednio 91 i 95,2\% oraz 148,5 i 156,6 Gy, natomiast objętości punktów gorących nieznacznie tą granicę przekraczały $\left(\mathrm{V}_{200-\mathrm{p}}: 15,7 \%\right.$ i 15,9\%). Parametry odpowiedzialne za informacje o wysokości dawek w obrębie narządów krytycznych nie powodowały konieczności korekty planu w ostatniej frakcji brachyterapii HDR (wyjątek $\mathrm{D}_{10-\mathrm{r}}$ $>65 \%$ w II frakcji leczenia). Natomiast ze względu na ryzyko martwicy popromiennej wynikającej z wyższej objętości dawki 200\%, przy biologicznej dawce frakcyjnej 165 Gy taka korekta była konieczna. W wyniku rygorystycznej kontroli parametrów $\mathrm{V}_{200-\mathrm{p}}, \mathrm{V}_{150-\mathrm{p}}$, $\mathrm{V}_{120-p} \mathrm{w}$ trzeciej frakcji uzyskano ich niższe wartości, przy czym istotność statystyczną zaobserwowano tylko w przypadku $\mathrm{V}_{120-\mathrm{p}}(\mathrm{p}=0,0247)$. Zmniejszyły się także parametry dawki

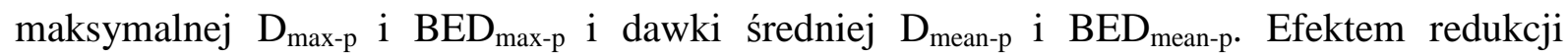
wysokich dawek w obszarze gruczołu krokowego okazał się spadek D90-p $_{9}$ i BED90-p w trzeciej frakcji, nieznacznie poniżej normy. Wpływ zmian na parametry dawek i objętości narządów okolicznych nie był istotny pod względem statystycznym. Korzystniejsze wartości parametrów dla cewki moczowej zaobserwowano w przypadku $\mathrm{D}_{\max -\mathrm{u}}, \mathrm{BED}_{\max -\mathrm{u}}, \mathrm{V}_{100-\mathrm{u}}, \mathrm{V}_{\text {crit- }}$ u. Odwrotny efekt uzyskano dla odbytnicy, gdzie parametry $\mathrm{D}_{10-\mathrm{r}}, \mathrm{BED}_{10-\mathrm{r}}, \mathrm{V}_{100-\mathrm{r}}, \mathrm{V}_{\text {crit-r }}, \mathrm{D}_{\text {max- }}$ r, BED $D_{\max -\mathrm{r}}$, uległy wyraźnemu pogorszeniu. W porównaniu parametrów pomiędzy frakcjami tych dwóch grup pacjentów widać zależność między wysokością dawek w odbytnicy i objętością dawek w punktach gorących obszaru gruczołu krokowego. Istotność statystyczna zmian prawdopodobnie zostanie osiągnięta po zwiększeniu liczebności grup kontrolnych.

Problem wpływu objętości punktów wysokiej dawki na późniejsze powikłania był poruszany w literaturze. Duchesne wraz ze współpracownikami zauważył, że nie wysokości dawek w narządach krytycznych, ale właśnie parametr $V_{200-p}$ koreluje ze zwiększonym ryzykiem późnych powikłań i śmierci u pacjentów po brachyterapii HDR [69]. Autor ustalił górną wartość parametru $\mathrm{V}_{200-p}$ na $15 \%$, zaznaczając fakt występowania powikłań popromiennych powyżej tej granicy, pomimo potencjalnego zysku w ilości zabitych komórek nowotworowych. Yoshioka badał toksyczność samodzielnej brachyterapii HDR u pacjentów ze wszystkich grup ryzyka, podając 54 Gy w 9 frakcjach, w ciagu 5 dni leczenia [70]. Przedstawiona częstotliwość występowania ostrych odczynów popromiennych w skali RTOG/EORTC wyniosła: 1 - 19\%, 2 - 28\%, 4- 2\%. U 5 pacjentów rozwinął się późny odczyn popromienny ze strony odbytnicy ( $1 \mathrm{z}$ owrzodzeniem, $4 \mathrm{z}$ krwawieniem $\mathrm{z}$ odbytu). Autor ustalił, że parametr $\mathrm{V}_{100-p}$ jest czynnikiem wpływającym na obecność ostrych i późnych 
odczynów popromiennych w monoterapii HDR [70]. Wpływ parametrów optymalizacyjnych na toksyczność późną w obrębie cewki i odbytnicy badali także Konishi i współpracownicy ze szpitala w Osace [71]. Pacjentów poddano samodzielnej brachyterapii HDR do dawki całkowitej 54 Gy w 9 frakcjach w ciagu 5 dni. Zaobserwowano wyższe wartości takich parametrów jak $\mathrm{V}_{20}, \mathrm{~V}_{40}, \mathrm{~V}_{50}, \mathrm{~V}_{60}, \mathrm{~V}_{70} \mathrm{w} \mathrm{cm}^{3}$ oraz $\mathrm{D}_{1} \mathrm{~cm}^{3}, \mathrm{D}_{2} \mathrm{~cm}^{3}, \mathrm{D}_{5} \mathrm{~cm}^{3}, \mathrm{D}_{10} \mathrm{~cm}^{3} \mathrm{~Gy}$ dotyczących odbytnicy, u 18 pacjentów, u których wystapiły krwawienia z dolnego odcinka przewodu pokarmowego $(27,7 \%)$. Istotność statystyczna najsilniej wyrażona była w przypadku $\mathrm{V}_{40}$ i $\mathrm{D}_{5} \mathrm{~cm}^{3}$. Częstotliwość występowania późnych odczynów popromiennych ze strony odbytnicy była wyższa, gdy $\mathrm{V}_{40}>8 \mathrm{~cm}^{3}(42 \%)$ oraz $\mathrm{D}_{5} \mathrm{~cm}^{3}>27 \mathrm{~Gy}(50 \%)$ [71]. Nie znaleziono istotnych korelacji pomiędzy parametrami planu leczenia dla cewki moczowej a występowaniem powikłań popromiennych tego organu ryzyka. W podsumowaniu pracy autorzy zaproponowali zastosowanie powyższych parametrów jako wartości ograniczających w akceptacji planu leczenia. W konkluzji cytowanej pracy stwierdzono, że w samodzielnej brachyterapii HDR pacjentów w celu uniknięcia poważnych powikłań, muszą być brane pod uwagę przede wszystkim parametry objętości dawek w gruczole krokowym oraz odbytnicy w mniejszym stopniu parametry cewki moczowej.

W rozprawie porównano parametry dawek i objętości w trzech schematach brachyterapii HDR w celu oceny jakości planowania leczenia i w zależności od wyników, propozycji zmian na przyszłość w poszczególnych schematach. Porównując wartości procentowe parametrów $\mathrm{D}_{90-\mathrm{p}}$ oraz $\mathrm{V}_{100-\mathrm{p}}$ zauważono ich niższe wartości dla gruczołu krokowego w schemacie EBRT 46 Gy/ BRT 2 x 10. Jednocześnie stosunkowo wysoka wartość parametru SD-p sugerowała w obrębie gruczołu krokowego dawkę mniej jednorodną, $\mathrm{z}$ obecnością większej objętości punktów nisko i wysokodawkowych. Nie dziwił zatem fakt, że wartości $\mathrm{V}_{200-p}$ oraz $\mathrm{D}_{\text {max-p }} \mathrm{dla}$ II grupy okazały się wyższe. Parametry dla grupy o niższej dawce frakcyjnej w cewce moczowej także różniły się na niekorzyść, w porównaniu ze schematami I i III. W odbytnicy niewielkie różnice pomiędzy wartościami oraz brak istotności statystycznej testów porównawczych nie pozwala na jednoznaczne wyciągnięcie wniosków w schemacie II. Stosując test Kruskala-Wallisa dla wartości procentowych (grupy I-III) czy Manna-Whitneya dla wartości dawek biologicznych (I i III) nie zauważono istotnych różnic u pacjentów z wysoką dawką frakcyjną - 15 Gy. Rozpatrując parametry wartości dawek i objętości planu leczenia, niezależnie od schematu należy pamiętać, że niosą one dla radioterapeuty określone informacje. Wyższe wartości punktów wysokiej dawki czy wyższe dawki w cewce moczowej dla grupy II nie muszą być problemem z powodu niskiej dawki fizycznej - 10 Gy, podawanej pacjentom. Natomiast niższa dawka w połączeniu z ryzykiem niedopromienienia $\left(\mathrm{D}_{90-\mathrm{p}}, \mathrm{V}_{100-\mathrm{p}}\right.$ 
poniżej normy) może doprowadzić do spadku prawdopodobieństwa kontroli miejscowej i niewyleczenia chorego. Dla pomyślnego wyniku brachyterapii HDR ważne okazuje się zatem aby w grupie z niską dawką frakcyjną zwrócić szczególną uwagę na odpowiednią objętość dawki 90\% w obrębie gruczołu, nawet kosztem zwiększonia wartości dawek w narządach okolicznych. W schemacie leczenia z zastosowaniem 15 Gy na frakcję koniecznością staje się kompromis z powodu wysokich dawek i znacznego ryzyka późnych, nieodwracalnych powikłań popromiennych. Powyższe wnioski może potwierdzać praca D’Souzy i współpracowników. Wyodrębnili oni czynniki planu leczenia takie jak: parametry $\mathrm{D}_{90-\mathrm{p}}, \mathrm{V}_{100-}$

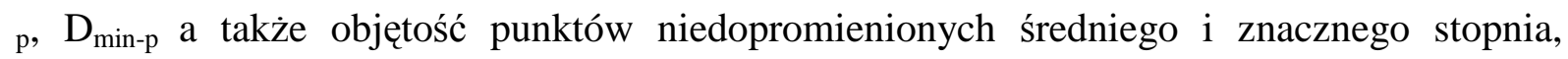
dokonując ponadto oceny ich wpływu na prawdopodobieństwo kontroli miejscowej (ang. tumor control probability - TCP) [72]. Tylko dawka podana na 90\% objętości i dawka minimalna okazały istotne statystycznie i wpływały wprost proporcjonalnie na TCP. W jednym z wniosków końcowych zaznaczono, że powyższe prawdopodobieństwo może być większe, gdy punkty znacznie niedopromienione są skupione na małej powierzchni niż w sytuacji występowania dawek nieznacznie poniżej normy na dużym obszarze. Podkreślono, że parametry $\mathrm{D}_{90-\mathrm{p}}$ i $\mathrm{V}_{100-\mathrm{p}}$ oznaczają różne dane na temat rozmieszczenia dawki w objętości gruczołu i nie można traktować ich równorzędnie [72]. Wpływu parametrów planu leczenia na powikłania po brachyterapii HDR w dawce frakcyjnej $10 \mathrm{~Gy}$, próbowali szukać Frohlich ze współpracownikami z ośrodka w Budapeszcie [73]. Ustalili oni, że parametry $\mathrm{D}_{2}$ dla odbytnicy oraz $\mathrm{D}_{1}$ dla cewki moczowej (dawki podane w 2 i $1 \%$ objętości) dobrze korelują z późniejszymi powikłaniami popromiennymi w tych narządach. W materiale przedstawionym wartości powyższych parametrów wynosiły odpowiednio: 49\% i 143\%. Dawki tolerancji dla narządów krytycznych nie zostały przekroczone a średnie dawki przedstawiały się dla odbytnicy i cewki następująco: 75\% i 120\% (założone pierwotnie 80\% i 125\%). Porównując dane uzyskane podczas brachyterapii pacjentów w Wielkopolskim Centrum Onkologii zwracają uwagę wyższe, maksymalne dawki w narządach okolicznych (odbytnica $-\mathrm{D}_{\max -\mathrm{r}} 84$ - 90\%, cewka $\mathrm{D}_{\max -u} 140$ - 144\%). Wynika to prawdopodobnie z wyboru różnych punktów akceptacji planu leczenia (w WCO jest to parametr $\mathrm{D}_{10-\mathrm{r}}$ i $\mathrm{D}_{10-\mathrm{u}}$ ). Niższe okazały się wartości parametru $\mathrm{D}_{90-\mathrm{p}}$ wynosząc dla ośrodka węgierskiego średnio 107\% (WCO to $88-92 \%$ ). Trudno powiedzieć, jakie przełożenie na wyniki leczenia może mieć wyższa, średnia objętość dawki podanej na $90 \%$ objętości gruczołu krokowego, akurat u tych chorych. Nie było to tematem powyższej publikacji [73]. Z wielu doniesień światowych wiadomo, że im wyższa dawka podana na obszar targetu, tym wyższe prawdopodobieństwo kontroli miejscowej. Swoistej metaanalizy dokonał Pieters, porównując wyniki samodzielnej EBRT i skojarzonej z 
brachyterapią HDR lub LDR, przedstawione w 40 publikacjach [74]. Wyniki jednoznacznie potwierdziły przewagę schematu leczenia z udziałem brachyterapii o wysokiej mocy dawki pod kątem kontroli biochemicznej oraz przeżycia całkowitego. Biorąc pod uwage powyższe prace, w radioterapii raka gruczołu krokowego należy możliwie zwiększać dawkę frakcyjną i dążyć do jak najwyższych parametrów objętości dawki referencyjnej, nawet kosztem większej dawki w narządach okolicznych. Autorzy poruszyli ponadto temat wpływu czynników prognostycznych na wyniki leczenia mężczyzn z rakiem w tej lokalizacji [74].

Przeprowadzona analiza korelacji czynników prognostycznych i parametrów dawek oraz objętości planu leczenia u mężczyzn leczonych w Zakładzie Brachyterapii miała na celu identyfikację czynników szczególnie wpływających na wysokości dawek w poszczególnych grupach i ułatwić dobór pacjentów do schematów leczenia. Czynnik wieku ważny okazał się w grupach II i III gdzie wpływał na parametry dawki w gruczole krokowym. W schemacie II starszy wiek obniżał wartość objętości dawki 100\%, w grupie III obniżał objętości dawek punktów gorących. Z punktu widzenia klinicznego, pomijając fakt towarzyszącego wzrostu dawki maksymalnej (niska dawka frakcyjna) należy zauważyć, że u pacjentów starszych w tej grupie istnieje ryzyko niedopromienienia objętości gruczołu, co może mieć bezpośredni wpływ na wyniki leczenia. Najsilniej korelującymi czynnikami okazały się jednak objętość gruczołu oraz liczba użytych do brachyterapii aplikatorów igłowych. Wraz ze wzrostem objętości poprawiały się parametry dawki 90\% i objętości dawki 100\%, zwiększając prawdopodobieństwo wyleczenia pacjentów we wszystkich grupach. Niejednoznaczny okazał się wpływ wzrostu objętości na wysokości dawek w cewce moczowej, w grupie I pogarszając parametry takie jak: $\mathrm{V}_{100-\mathrm{u}}, \mathrm{D}_{\text {mean-u}}, \mathrm{BED}_{\text {mean-u }}$, w II obniżając dawkę maksymalną. Korelacja w przypadku odbytnicy wykazała w grupie II wzrost dawki podanej na 10\% objętości, wzrost dawki $\mathrm{D}_{\text {min-r }}$ dla grupy III nie miał znaczenia praktycznego. Wpływ większej liczby igieł generalnie był korzystny dla procesu leczenia. Zauważono wzrost wartości $D_{90-p}$ i $V_{100-p}$, spadek $\mathrm{V}_{200-\mathrm{p}} \mathrm{W}$ grupie $\mathrm{I}$, a także poprawę parametrów odbytnicy $\left(\mathrm{V}_{100-\mathrm{r}} \mathrm{W} \mathrm{I}\right)$ oraz cewki $\left(\mathrm{D}_{\text {max }}\right.$ u, BED $D_{\text {max-u }}$ w II). Biorąc pod uwagę fakt wysokiej dawki frakcyjnej i całkowitej uwagę zwraca zwiększenie objętości dawek wysokich w grupie III (ryzyko martwicy popromiennej). Nie zanotowano znaczącego wpływu takich czynników jak poziom PSA, stopień zaawansowania klinicznego wg. skali TNM. Wpływ stopnia zróżnicowania komórkowego ograniczał się tylko do parametrów dawek i objętości w odbytnicy, w schemacie I skojarzonego leczenia.

Zaobserwowane korelacje znaczenie praktyczne wykazały dla trzech parametrów prognostycznych. Na ich podstawie można przedstawić pewne zalecenia dotyczące doboru 
pacjentów do schematów leczenia. Zauważono, że chorzy w starszym wieku powinni być leczeni jedną frakcją BRT-HDR (brak wpływu czynników prognostycznych na parametry narządów krytycznych, jednorazowy zabieg w znieczuleniu ogólnym). Pacjenci starsi, kwalifikowani do schematu EBRT 46 Gy/BRT-HDR 2 x 10 Gy uzyskali niższą wartość dawki $100 \%$ i z powodu niskiej dawki frakcyjnej oraz ryzyka niedopromienienia, nie powinni być w tym schemacie leczeni. U pacjentów w młodszym wieku należy unikać monoterapii HDR ze względu na ryzyko wzrostu dawek w obrębie gruczołu i ryzyko powikłań popromiennych. Wzrost objętości gruczołu przeważnie poprawiał parametry dawki 90\% dla gruczołu krokowego, niejednoznacznie wpływając na cewkę moczową i odbytnicę. W świetle powyższych obserwacji słuszne wydaje się nie kwalifikowanie pacjentów ze znaczną objętością gruczołu do grupy I (korelacja objętość a $\mathrm{V}_{100-\mathrm{u}}, \mathrm{V}_{\text {crit-u}}, \mathrm{D}_{\text {mean-u}}, \mathrm{BED}_{\text {mean-u }}$ dodatnia). W grupie II natomiast konieczna jest ostrożność u chorych, u których występuje odczyn popromienny w odbytnicy, pomimo niskich dawek zastosowanych w brachyterapii (wzrost dawek $\mathrm{D}_{10-\mathrm{r}}, \mathrm{BED}_{10-\mathrm{r}}, \mathrm{D}_{\text {mean-r }}$, $\mathrm{BED}_{\text {mean-r }}$ wraz ze wzrostem rozmiarów gruczołu). Liczba użytych aplikatorów igłowych korelowała z lepszym rozkładem dawki (wzrost $\mathrm{D}_{90-\mathrm{p}}$, spadek $\left.\mathrm{SD}_{-\mathrm{p}}\right)$, ze zmniejszeniem objętości punktów gorących $\left(\mathrm{V}_{200-\mathrm{p}}\right)$ oraz spadkiem dawki w odbytnicy $\left(\mathrm{V}_{100-\mathrm{r}}\right)$ i cewce moczowej $\left(\mathrm{D}_{\max -\mathrm{u}}, \mathrm{BED}_{\max -\mathrm{u}}\right)$. Trzeba jednak zwrócić szczególną uwagę na schemat monoterapii HDR, gdzie większa liczba igieł - tylko w tej grupie skutkowała wzrostem parametrów $\mathrm{V}_{150-\mathrm{p}}, \mathrm{V}_{120-\mathrm{p}}$. Należy rozważyć więc zastosowanie w tej grupie mniejszej liczby aplikatorów.

Nawiązując do powyższych obserwacji do rozważenia pozostaje wpływ poszczególnych czynników prognostycznych na wyniki leczenia pacjentów z rakiem gruczołu krokowego. Tym zagadnieniem zajmował się Pilepich w ramach badania RTOG 75-06, a pod uwage wzięto takie czynniki jak wiek, rasa, rozmiar guza, poziom fosfatazy kwaśnej, stan węzłów chłonnych, stopień zróżnicowania komórkowego oraz sytuację hormonalną chorych [75]. W badaniu tym, wiek i rozmiar guza gruczołu krokowego silnie wpływały na współczynnik kontroli miejscowej. Wzrost poziomu fosfatazy, brak leczenia hormonalnego, duży rozmiar guza korelowały ze wzrostem częstotliwości występowania przerzutów odległych. Młody wiek pacjentów okazał się czynnikiem tutaj niekorzystnym. Badany w pracy stopień zróżnicowania (skala Gleasona) znacząco wpływał na wszystkie współczynniki (przeżycie całkowite, przeżycie bez oznak choroby, kontrolę miejscową, występowanie przerzutów odległych) [75]. Objętość gruczołu jest kluczowym czynnikiem w prognozowaniu wielkości dawek podanych w brachyterapii HDR raka tego narządu. Korzystną korelację rozmiarów gruczołu krokowego z wartościami parametrów dawek i objętości pod kątem późniejszych 
powikłaniań po leczeniu przedstawili Monroe ze współpracownikami [65]. Uzyskali bardzo dobre parametry u pacjentów z objętością gruczołu powyżej $50 \mathrm{~cm}^{3}\left(\mathrm{D}_{90-\mathrm{p}}\right.$ : $109 \%, \mathrm{~V}_{100-\mathrm{p}}$ : $96 \%, \mathrm{~V}_{150-\mathrm{p}}: 18,3 \%$ ). Rozpatrując $\mathrm{w}$ tej pracy częstotliwość powikłań po brachyterapii, $11 \%$ chorych doświadczyło ostrego zatrzymania moczu, u 1,8\% wystąpił odczyn popromienny 2 stopnia ze strony odbytnicy (bez krwawienia), u 1,8\% zanotowano zwężenie cewki moczowej. Częstotliwość powikłań ostrych była więc nieznacznie wyższa ale akceptowalna w świetle bardzo dobrych wartości parametrów dawek i objętości [65].

Wpływu małej objętości gruczołu (poniżej $10 \mathrm{~cm}^{3}$ ) na wartość parametrów nie badał nikt, ale należy przypuszczać, że z powodu małych odległości pomiędzy aplikatorami (wysokie dawki punktów gorących), bliskiego położenia igieł przy narządach krytycznych, parametry powinny być mniej korzystne. Dużo więcej uwagi poświęca się ostatnio w brachyterapii HDR liczbie użytych igieł oraz ich przemieszczeniu pomiędzy frakcjami, względem siebie i objętości gruczołu krokowego. Vargas wykazał, że stosowanie w leczeniu raka hormonoterapii oraz liczby igieł powyżej 14/frakcję koreluje z wyższym odsetkiem powikłań popromiennych 2 stopnia, ze strony układu moczowego [64]. Simnor ze współpracownikami przedstawił wagę problemu przesunięć igieł $\mathrm{w}$ trakcie leczenia [76]. Z frakcji na frakcję bez korekty przesunięcia parametr $\mathrm{D}_{90-\mathrm{p}}$ Zmniejszał się odpowiednio przed 2 i 3 frakcją o wartość: $27,8 \%$ i $32,3 \%$. Jednocześnie wzrosły parametry $\mathrm{D}_{2} \mathrm{~cm}^{3}$ dla odbytnicy odpowiednio o $0,69 \mathrm{i}$ 0,75 Gy oraz $\mathrm{V}_{12}$ dla cewki o 0,36 i 0,39 Gy [76]. Brak korekty położenia igieł pomiędzy frakcjami może skutkować więc, niedopromienieniem gruczołu i niepowodzenie leczenia. Tiong przedstawił wartość TCP w zależności od stopnia przemieszczenia aplikatorów igłowych w kierunku doogonowym [77]. Średnia, względna wartość współczynnika kontroli miejscowej wyniosła od 0,998 do 0,265 przy przesunięciach igieł odpowiednio od 3 do 12 mm. W ośrodkach, które nie mają możliwości technicznych monitorowania pacjentów pod tym kątem, lepszym rozwiązaniem wydaje się być zastosowanie brachyterapii w pojedynczej dawce jako $t z w$. boost po teleradioterapii. Znaczenie tego problemu jest oczywiste dla radioterapeuty, szczególnie przy projektowaniu badań i zastosowaniu brachyterapii HDR w leczeniu samodzielnym, w grupie pacjentów o korzystnych czynnikach prognostycznych.

Biorąc pod uwagę wyniki niniejszej pracy oraz przedstawione dane z publikacji światowych, na wysokość dawek podanych w trakcie leczenia oraz na jego wyniki mogą mieć wpływ parametry wieku, objętości gruczołu oraz liczby użytych igieł. Młodszy wiek pacjentów to większe ryzyko niedopromienienia gruczołu (zaobserwowane dane) oraz gorsze wyniki brachyterapii (piśmiennictwo), co sugeruje rezygnację z tego typu leczenia i zastosowanie samodzielnej teleradioterapii. Pacjenci kwalifikowani do leczenia brachyterapią, niezależnie 
od schematu, powinni być przede wszystkim analizowani pod kątem objętości gruczołu krokowego i możliwości zastosowania jak największej ilości aplikatorów igłowych. Wyższa objętość i większa liczba igieł poprawia wartości DVH planu, zwiększa prawdopodobieństwo wyleczenia i minimalizuje częstotliwość powikłań. Mniejsza objętość gruczołu, z koniecznością użycia mniejszej liczby aplikatorów, zlokalizowanych blisko siebie powinna być czynnikiem dyskwalifikującym od brachyterapii HDR. Koniecznym wydaje się przeprowadzenie badań i ustalenie dolnej granicy objętości gruczołu umożliwiającej skuteczną i bezpieczną procedurę HDR-BRT. 


\section{Wnioski}

1. Wysokość dawki w obszarze referencyjnym (gruczoł krokowy) ulegała obniżeniu po korekcie dawki w odbytnicy, podobną zależność zaobserwowano dla wartości dawek w cewce moczowej. Wzrost dawki frakcyjnej zwiększa ryzyko nieoczekiwanych wartości dawek i objętości w obszarze napromienianym i narządach krytycznych.

2.Oznacza to, że dążenie do obniżenia dawek celem oszczędzenia narządów zdrowych może wiązać się z mniej korzystnym rozkładem dawki w obrębie narządu leczonego - gruczołu krokowego.

3. W grupie III wzrost wieku był powiązany z korzystniejszym rozkładem dawek. W grupie II niższy wiek był związany z obniżeniem dawki w obszarze referencyjnym oraz wzrostem w narządach krytycznych. Wzrost objętości gruczołu krokowego we wszystkich grupach korelował z lepszym rozkładem dawki. Wiązała się z tym większa liczba zastosowanych aplikatorów w grupie I i II, jedynie w grupie III wraz ze wzrostem liczby aplikatorów wzrastało niebezpieczeństwo wzrostu dawek w obrębie gruczołu krokowego.

4. Stwierdzono zależność analizowanych wyników prognostycznych: wieku, objętości gruczołu i liczby aplikatorów z wartościami dawek w obszarze referencyjnym oraz narządach krytycznych.

Powyższe obserwacje sugerują ryzyko uzyskania gorszego rozkładu dawki HDR-BRT w grupie młodych mężczyzn o niewielkiej objętości gruczołu krokowego. 


\section{Spis tabel i rycin}

Tabela 1. TNM wg AJCC/UICC 2002.

Tabela 2. Grupy ryzyka raka gruczołu krokowego (N0,M0).

Tabela 3. Wskazania do brachyterapii raka gruczołu krokowego (zalecenia Amerykańskiego Towarzystwa Brachyterapii).

Tabela 4. Dane pacjentów przyporządkowanych do grup wg schematów leczenia.

Tabela 5. Porównanie efektywnych dawek biologicznych (BED) oraz dawek ekwiwalentnych (EQD2) w różnych schematach radioterapii.

Tabela 6. Parametry dawek i objętości dla gruczołu krokowego, cewki moczowej, odbytnicy wykorzystane w korelacjach statystycznych.

Tabela 7. Dawki akceptacji planu leczenia (DVC) dla poszczególnych narządów.

Tabela 8. Statystyka opisowa parametrów prognostycznych dla gruczołu krokowego w trzech grupach.

Tabela 9. Statystyka opisowa parametrów dawek i objętości dla gruczołu krokowego $(\alpha / \beta=1,5)$ w trzech grupach wg schematów leczenia.

Tabela 10. Statystyka opisowa parametrów dawek i objętości dla cewki moczowej $(\alpha / \beta=3)$ w trzech grupach wg schematów leczenia.

Tabela 11. Statystyka opisowa parametrów dawek i objętości dla odbytnicy $(\alpha / \beta=3)$ w trzech grupach wg schematów leczenia.

Tabela 12. Porównanie parametrów dawek i objętości w zależności od liczby frakcji dla gruczołu krokowego $(\alpha / \beta=1,5)$, cewki moczowej, odbytnicy $(\alpha / \beta=3)$ w odpowiednich grupach.

Tabela 13. Porównanie zmienności parametru $\mathrm{V}_{120-\mathrm{p}} \mathrm{W}$ trzech frakcjach brachyterapii, dla III grupy w teście Dunn’a.

Tabela 14. Porównanie parametrów dawek i objętości w zależności od schematu brachyterapii HDR dla gruczołu krokowego $(\alpha / \beta=1,5)$, cewki moczowej $(\alpha / \beta=3)$.

Tabela 15. Porównanie zmienności parametru $\mathrm{SD}_{-\mathrm{p}} \mathrm{W}$ trzech schematach brachyterapii HDR w teście Dunn'a.

Tabela 16. Porównanie zmienności parametru $\mathrm{V}_{120-\mathrm{p}} \mathrm{W}$ trzech schematach brachyterapii HDR w teście Dunn'a.

Tabela 17. Porównanie zmienności parametru $\mathrm{D}_{\max -\mathrm{p}} \mathrm{W}$ trzech schematach brachyterapii HDR w teście Dunn'a. 
Tabela 19. Porównanie zmienności parametru $\mathrm{D}_{\text {min-u }} \mathrm{W}$ trzech schematach brachyterapii HDR w teście Dunn'a.

Tabela 20. Porównanie zmienności parametru $\mathrm{V}_{100-\mathrm{u}} \mathrm{W}$ trzech schematach brachyterapii HDR w teście Dunn'a.

Tabela 21. Porównanie zmienności parametru $\mathrm{SD}_{-\mathrm{u}} \mathrm{w}$ trzech schematach brachyterapii HDR w teście Dunn'a.

Tabela 22.Wyniki analizy statystycznej testu korelacji Spearmana pomiędzy czynnikami prognostycznymi a wartościami dawek i objętości gruczołu krokowego.

Tabela 23.Wyniki analizy statystycznej testu korelacji Spearmana pomiędzy czynnikami prognostycznymi a wartościami dawek i objętości cewki moczowej.

Tabela 24.Wyniki analizy statystycznej testu korelacji Spearmana pomiędzy czynnikami prognostycznymi a wartościami dawek i objętości odbytnicy.

Rycina 1. Sposoby korelacji statystycznej pomiędzy schematami leczenia.

Rycina 2. Porównanie wartości parametru dla odbytnicy $\mathrm{V}_{100-\mathrm{r}}$ pomiędzy dwiema Frakcjami, II grupa.

Rycina 3. Porównanie wartości parametru dla $\mathrm{V}_{120-\mathrm{p}} \mathrm{w}$ trzech frakcjach, III grupa.

Rycina 4. Porównanie wartości parametru dla $\mathrm{D}_{90-\mathrm{p}} \mathrm{w}$ trzech frakcjach, III grupa.

Rycina 5. Porównanie wartości parametru dla $\mathrm{BED}_{90-\mathrm{p}} \mathrm{w}$ trzech frakcjach, III grupa.

Rycina 6. Porównanie wartości parametru dla $\mathrm{V}_{100-\mathrm{p}} \mathrm{w}$ trzech frakcjach, III grupa.

Rycina 7. Porównanie wartości parametru $\mathrm{D}_{10-\mathrm{u}}$ dla cewki moczowej w trzech frakcjach, III grupa.

Rycina 8. Porównanie wartości parametru $\mathrm{BED}_{10-\mathrm{u}}$ dla cewki moczowej w trzech frakcjach, III grupa.

Rycina 9. Porównanie wartości parametru dla $\mathrm{SD}_{-\mathrm{p}} \mathrm{w}$ trzech schematach brachyterapii HDR.

Rycina 10. Porównanie wartości parametru dla $\mathrm{V}_{120-\mathrm{p}} \mathrm{w}$ trzech schematachbrachyterapii HDR.

Rycina 11. Porównanie wartości parametru dla $D_{\text {max-p }} w$ trzech schematach brachyterapii HDR.

Rycina 12. Porównanie wartości parametru dla $\mathrm{D}_{\text {mean-u }} \mathrm{w}$ trzech schematach brachyterapii HDR.

Rycina 13. Porównanie wartości parametru dla $D_{\text {min-u }} w$ trzech schematach brachyterapii HDR.

Rycina 14. Porównanie wartości parametru dla $\mathrm{V}_{100-\mathrm{u}} \mathrm{W}$ trzech schematach brachyterapii HDR. 
Rycina 15. Porównanie wartości parametru dla $\mathrm{SD}_{-\mathrm{u}} \mathrm{w}$ trzech schematach brachyterapii HDR. 


\section{Piśmiennictwo}

1, Dobruch J, Borówka A, Antoniewicz AA, Chłosta P: Epidemiologia raka gruczołu krokowego: zmiany obserwowane w Polsce w latach 1991 - 2001. Urol Pol 2005; 58: 1.

2. Didkowska J, Wojciechowska U, Tarkowski W, Zatoński W: Nowotwory złośliwe w Polsce w 2000 r. Centrum Onkologii - Instytut im M. Skłodowskiej-Curie;w: Krajowy Rejestr Nowotworów; Warszawa 2003.

3. Wojciechowska U, Didkowska J, Zatoński W: Nowotwory złośliwe w Polsce w 2006 r. Centrum Onkologii - Instytut im M. Skłodowskiej-Curie;w: Krajowy Rejestr Nowotworów; Warszawa 2008.

4. Krajowy Rejestr Nowotworów: http://85.128.14.124/krn/.

5. Krzakowski M, Herman K, Jassem J, Jędrzejczak W, Kowalczyk JR, Podolak-Dawidziak i wsp.: Zalecenia postępowania diagnostyczno-terapeutycznego w nowotworach złośliwych. Via Medica 2007, 3, supl C: 274-76.

6. Brawer MK: Prostate-specific antygen: Current status. CA Cancer J Clin 1999; 49: 264-81.

7. Sudol-Szopińska I, Szopiński T: Diagnostyka ultrasonograficzna gruczołu krokowego. Roztoczańska Szkoła Ultrasonografii; Warszawa 2005,1: 23-56.

8. Murphy GP, Busch C, Abrahamsson PA, Epstein JI, Mc Neal JE, Miller GJ i wsp.: Histopathology of localised prostate cancer. Consensus Conference on Diagnosis and Prognostic Parameters in Localized Prostate Cancer. Stockholm, Sweden, May 12-13, 1993. Scand J Urol Nephrol 1994, 162: 7-42.

9. Gleason D.F., Mellinger G.T.: Veterans Administration cooperative Urological Research Group: Prediction of prognosis for prostatic adenocarcinoma by combined histhologic grading and clinical staging. J Urol 1974; 1158-64.

10. Chwaliński T: Rak stercza: rozpoznanie i leczenie. Nowa Medycyna 2001; 113: 5-6.

11. Greene FL i wsp.: TNM staging of urothelial tract cancer. AJCC Cancer Staging Manual (wyd. 6): New York: Springer-Verlag 2002.

12. Klein EA, Ciezki J, Kupelian PA, Mahadevan A: Outcomes for intermediate risk prostate cancer: are the advantages for surgery, external radiation or brachytherapy? Urol Oncol 2009; 27: 67-71.

13. Kupelian PA, Elshaikh, Reddy CA, Zippe C, Klien EA: Comparison of the efficacy of local therapies for localized prostate cancer in the prostate-specific antygen era: A large single-institution experience with radical prostatectomy and external-beam radiotherapy. $\mathrm{J}$ Clin Oncol 2002; 20: 3376-85.

14. Jareczek-Fossa BA: Rola radioterapii w leczeniu raka gruczołu krokowego. Współcz Onkol 2003; 7: 176-82.

15. National Comprehensive Cancer Network 1.2009, www.nccn.org. 
16. Baust JG, Gage AA, Robilotto AT, Baust JM: The pathophysiology of thermoablation: optimizing cryoablation. Curr Opin Urol 2009; 19: 127-32.

17. Marberger M, Carrol PR, Zelefsky MJ, Coleman JA, Hricak H, Scardino PT i wsp.: New treatments for localized prostate cancer. Urology 2008; 72: 36-43.

18. Pfitzenmaier J, Altwein JE: LHRH anlogues for the tratment of prostate cancer: an evidence lavel-based analysis. Aktuelle Urol 2009; 40: 100-08.

19. Petrylak DP: Docetaksel for the treatment of hormone-refractory prostate cancer. Rev Urol 2003; 5, suppl 3: 14-21.

20. Schultheiss D, Waldbaum RS: Historia chorób gruczołu krokowego. Przegl Urol 200; 8, 1.

21. Matuszewski M, Matuszewska K, Jassem J: Leczenie operacyjne raka gruczołu krokowego. Współcz Onkol 2003; vol 7; 3: 171-75.

22. Reuter MA, Dietz K: Radical transurethral resection of the prostate. An alternative therapy for the treatment of prostate cancer. Urologe A 2009; 48: 740-47.

23. Aus G, Abbou CC, Pacik D I wsp.: EAU Guidelines on Prostate Cancer 2001.

24. Hull GW, Rabbani F, Abbas F: Cancer control with radical prostatectomy alone with 1000 consecutive patients. J Urol 2002; 167: 528-34.

25. Hautmann RE, Sauler TW, Wenderoth UK: Radical retropubic prostatectomy: morbidity and urinary continence in 418 consecutive cases. Urology 1994; 43: 47-51.

26. Dearnaley DP: Radiotherapy and combined modality approaches in localized prostate cancer. Eur J Cancer 2001; 37 (suppl 7): 137-45.

27. Zagars GK, von Eschenback AC, Johnson DE, Oswald MJ: Stage C adenocarcinoma of the prostate: An analysis of 551 patients treated with external beam radiation. Cancer 1987; 60: 1489-99.

28. Kelovic VL, Bukovic D, Badzek S, Curic Z, Kelovic Z, Persec Z i wsp.: Sex or surgeryerectile dysfunction after radical treatment of localized prostate cancer. Coll Antropol 2009; 33: 443-47.

29. Pollack A, Zagars GK, Starkschall G, Antolak JA, Lee JJ, Huang E i wsp.: Prostate cancer radiation dose response: Results of the M.D. Anderson phase III randomised trial. Int J Radiat Oncol Biol Phys 2002; 53: 1097-1105.

30. Hanks GE, Matrz KL, Diamond JJ: The effect of dose on local control of prostate cancer. Int J Radiat Oncol Biol Phys 1988: 15; 1299 - 1305.

31. Pollack A, Zagars GK, Smith LG, Lee JJ, Huang E, von Eschenbach AC i wsp.: Preliminary results of a randomized radiotherapy dose-escalation study comparing 70 with 78 Gy for prostate cancer. J Clin Oncol 2000; 18: 3904 - 11. 
32. Zelefsky M, Fuks Z, Happersett L, Lee JH, Ling CC, Burman CM i wsp.: Clinical experience with intensity modulated radiation therapy (IMRT) in prostate cancer. Radiother Oncol 2000; 55: 241-49.

33. Cellini N, Morganti AG, Mattiucci GC, Valentini V, Leone M, Luzi S i wsp: Analysis of intraprostatic failures in patients treated with hormonal therapy and radiotherapy: implications for conformal therapy planning. Int J Radiat Oncol Biol Phys 2002; 53: 595-99.

34. Dawson LA, Sharpe MB: Image-guided radiotherapy: rationale, benefits and limitations. Lancet Oncol 2006; 7: 848-58.

35. Jaffray DA, Bissonnette JP, Craig T: X-ray imaging for verification and localization in radiation therapy in modern technology of radiation oncology. Modern Technology of Radiation Oncology. Madison, WI: Medical Physics Pub. 1999 ISBN: 0-944838-38-3.

36. Fowler JF: The radiobiology of prostate cancer including new aspects of fractionated radiotherapy. Acta Oncol 2005; 44: 265-76.

37. Brenner DJ, Hall EJ: Fractionation and protraction for radiotherapy of prostate carcinoma. Int J Radiat Oncol Biol Phys 1999; 43: 1095-1101.

38. Wang JZ, Li XA, Yu CX, DiBiase SJ: The low alpha/beta ratio for prostate cancer: what does the clinical outcome of HDR brachytherapy tell us? Int J Radiat Oncol Biol Phys 2003; 57: 1101-08.

39. Lukka H, Hayter C, Julian JA, Warde P, Morris WJ, Gospodarowicz M i wsp: Randomized trial comparing two fractination schedules for patients with localized prostate cancer. J Clin Oncol 2005; 23: 6132-38.

40. Yeoh EE, Hollway RH, Fraser RJ, Botten RJ, Matteo AC, Butters J i wsp: Hypofractionated versus conventionally fractionated radiation therapy for prostate carcinoma: updated results of a phase III randomized trial. Int J Radiat Oncol Biol Phys 2006; 66: 107283.

41. Pollack A, Hanlon AL, Horwitz EM, Feigenberg SJ, Konski AA, Movsas B i wsp.: Dosimetry and preliminary acute toxicity in the first 100 men treated for prostate cancer on a randomized hypofractionation dose escalation trial. Int J Radiat Oncol Biol Phys 2006; 64: 518-26.

42. Ishiyama H, Kitano M, Satoh T, Kotani S, Uemae M, Matsumoto K i wsp.: Genitourinary toxicity after high-dose-rate (HDR) brachytherapy combined with hypofractionated external beam radiotherapy for localized prostate cancer: an analysis to determine the correlation between dose-volume histogram parameters in HDR brachytherapy and severity of toxicity. Int J Radiat Oncol Biol Phys 2009; 75: 23-28.

43. Barringer BS: Radium in the treatment of prostatic carcinoma. Ann Surg 1924; 80: 88184.

44. Young HH: The use of radium and the punch operation in desperate cases of enlarged prostate. Ann Surg 1917; 65: 633-41. 
45.Flocs RH: Interstitial irridiation therapy with a solution of Au198 as a part of combination therapy for prostatic carcinoma. J Nucl Med 1964; 5: 691-705.

46. Watanabe H, Kato H, Kato T, Morita M, Tanaka M: Diagnostic application of ultrasonotomography to the prostate. Nippon Hinyokika Gakkai Zasshi 1968; 59: 273-79.

47. Holm HH, Juul N, Pedersen JF, Hansen H, Stroyer I: Transperineal J-125 seed implantation in prostatic cancer guided by transrectal ultrasonography. J Urol 1983; 130: 28386.

48. Bertermann H, Brix F: Ultrasonically guided high-dose rate brachytherapy with 192Ir: technique and preliminary results in locally confined prostate cancer. w: Martinez AA, Orton CG, Mould RF, red. Brachytherapy HDR and LDR: remote afterloading state-of-the-art. Columbia: Nucletron 1990: 281-303.

49. Kanikowski M, Skowronek J, Milecki P, Kubaszewska M, Chicheł A: Brachyterapia HDR raka gruczołu krokowego. Urol Pol 2007; 2: 5-11.

50. Nag S, Baird J, Blasko JC: American Brachytherapy Society Survey of Current Clinical Practice for Permanent Brachytherapy of Prostate Cancer J Brachytherapy Int 1997; 13: 243 51.

51. Kupelian PA, Potters L, Khuntia D, Ciezki JP, Reddy CA, Reuther AM i wsp.: Radical prostatectomy, external beam radiotherapy $<72 \mathrm{~Gy}$, external beam radiotherapy $>$ or $=72 \mathrm{~Gy}$, permanent seed implantation, or combined seeds/external beam radiotherapy for stage T1-T2 prostate cancer. Int J Radiat Oncol Biol Phys 2004; 58: 25-33.

52. Morris DE, Emami B, Mauch PE, Konski AA, Tao ML, NG AK i wsp.: Evidence-based review of three-dimensional conformal radiotherapy for localized prostate cancer: an ASTRO outcomes initiative. Int J Radiat Oncol Biol Phys 2005; 62: 3-19.

53. Pellizzon AC, Nadalin W, Salvajoli JV, Fogaroli FC, Novaes PE, Maia MA i wsp.: Results of high dose afterloading brachytherapy boost to conventional external beam radiation therapy for initial and locally advanced prostate cancer. Radiother Oncol 2003; 66: 167-72.

54. Hiratsuka J, Jo Y, Yoshida K, Nagase N, Fujisawa M, Imajo Y: Clinical results of combined treatment conformal high-dose-rate iridium-192 brachytherapy and external beam radiotherapy using staging lymphadenectomy for localized prostate cancer. Int J Radiat Oncol Biol Phys 2004; 59: 684-90.

55. Martinez A, Demanes J, Vargas C, Schour L, Ghilezan M, Gustafson GS: High-DoseRate Prostate Brachytherapy: An Excellent Accelerated-Hypofractionated Treatment for Favorable Prostate Cancer. Am J Clin Oncol. 2009: November 30.

56. Ghadjar P, Keller T, Rentsch CA, Isaak B, Behrensmeier B, Stroux A i wsp.: Toxicity and early treatment outcomes in low- and intermediate-risk prostate cancer managed by highdose-rate brachytherapy as a monotherapy. Brachytherapy 2009; 8: 45-51.

57. Kanikowski M, Skowronek J, Chicheł A: HDR brachytherapy of prostate cancer -2 years of experience in Greater Poland Cancer Center. J Contemp Brachyter 2009; 1, 3 :137-44. 
58. Chicheł A, Kanikowski M, Skowronek J: Vital role of volume and number of needles in HDR brachytherapy (HDR-BT) of prostate cancer. J Contemp Brachyter 2009; 1, 3: 145-50.

59. Kovacs G, Potter R, Loch T, Hammer J, Kolkman-Deurlo IK, de la Rosette JJ i wsp.: GEC/ESTRO-EAU recommendations on temporary brachytherapy using stepping sources for localised prostate cancer. Radiother Oncol 2005; 74: 137-48.

60. Chung HT, Speight JL, Roach M: Intermediate- and High-Risk Prostate Cancer. In: Halperin EC, Perez CA, Brady LW (red). Principles and Practice of Radiation Oncology. Wyd. V. Lippincott Williams \& Wilkins, Philadelphia 2008; 63: 1483-1504.

61. Ślosarek K, Bystrzycka J, Fijałkowski M: Real time brachytherapy for prostate cancer - A new challenge for medical physicists. Rep Pract Oncol Radiother 2005; 10: 255-59.

62. Maciejewski B: Tolerancja zdrowych tkanek w radioterapii nowotworów. Odczyny popromienne. Wydawnictwo Centrum Onkologii Instytutu im. Marii Skłodowskiej-Curie. Gliwice. Rozdz. 6: 99-102.

63. Nickers P, Thissen B, Jansen N, Deneufbourg JM: 192Ir or 125I prostate brachytherapy as a boost to external beam radiotherapy in locally advanced prostatic cancer: a dosimetric point of view. Radiother Oncol 2006; 78: 47-52.

64. Vargas C, Ghilezan M, Hollander M, Gustafson G, Korman H, Gonzalez J I wsp.: A new model using number of needles and androgen deprivation to predict chronic urinary toxicity for high or low dose rate prostate brachytherapy. J Urol 2005; 174: 882-87.

65. Monroe AT, Faricy PO, Jennings SB, Biggers RD, Gibbs GL, Peddada AV: High-doserate brachytherapy for large prostate volumes $(>$ or $=50 \mathrm{cc})$ - Uncompromised dosimetric coverage and acceptable toxicity. Brachytherapy 2008; 7: 7-11.

66. Kalakota K, Rakhno E, Pelizzari CA, Jani AB, Liauw SL: Late rectal toxicity after prostate brachytherapy: Influence of supplemental external beam radiation on dose-volume histogram analysis. Brachytherapy 2010; 9: 131-36.

67. Ghadjar P, Matzinger O, Isaak B, Behrensmeier F, Stroux A, Rentsch CA i wsp.: Association of urethral toxicity with dose exposure in combined high-dose-rate brachytherapy and intensity-modulated radiation therapy in intermediate- and high-risk prostate cancer. Radiother Oncol. 2009; 91: 237-42.

68. Pinkawa M, Fischedick K, Treusacher P, Asadpour B, Gagel B, Piroth MD i wsp.: Dosevolume impact in high-dose-rate Iridium-192 brachytherapy as a boost to external beam radiotherapy for localized prostate cancer - a phase II study. Radiother Oncol 2006; 78: 4146.

69. Duchesne GM, Das R, Toye W, See A: Dose distribution and morbidity after high dose rate brachytherapy for prostate cancer: influence of V150 and V200 parameters. Australas Radiol 2002; 46: 384-89.

70. Yoshioka Y, Nose T, Yoshida K, Oh RJ, Yamada Y, Tanaka E i wsp.: High-dose-rate brachytherapy as monotherapy for localized prostate cancer: a retrospective analysis with 
special focus on tolerance and chronic toxicity. Int J Radiat Oncol Biol Phys 2003; 56: 21320.

71. Konishi K, Yoshioka Y, Isohashi F, Sumida I, Kawaguchi Y, Kotsuma T i wsp.: Correlation between dosimetric parameters and late rectal and urinary toxicities in patients treated with high-dose-rate brachytherapy used as monotherapy for prostate cancer. Int J Radiat Oncol Biol Phys 2009; 75: 1003-07.

72. D'Souza WD, Thames HD, Kuban DA: Dose-volume conundrum for response of prostate cancer to brachytherapy: summary dosimetric measures and their relationship to tumor control probability. Int J Radiat Biol Phys 2005; 62: 298-99.

73. Fröhlich G, Agoston P, Lövey J, Somogyi A, Fodor J, Major T: Dosimetric evaluation of interstitial high-dose-rate implants for localised prostate cancer. Magy Onkol 2007; 51: 31-38.

74. Pieters BR, de Back DZ, Koning CC, Zwinderman AH: Comparison of three radiotherapy modalities on biochemical control and overall survival for the treatment of prostate cancer: a systematic review. Radiother Oncol 2009; 93: 168-73.

75. Pilepich MV, Krall JM, Sause WT, Johnson RJ, Russ HH, Hanks GE i wsp.: Prognostic factors in carcinoma of the prostate - analysis of RTOG study 75-06. Int J Radiat Oncol Biol Phys 1987; 13: 339-49.

76. Simnor T, Li S, Lowe G, Ostler P, Bryant L, Chapman C i wsp.: Justification for interfraction correction of catheter movement in fractionated high dose-rate brachytherapy treatment of prostate cancer. Radiother Oncol 2009; 93: 253-58.

77. Tiong A, Bydder S, Ebert M, Caswell N, Waterhouse D, Spry N i wsp.: A small tolerance for catheter displacement in high-dose rate prostate brachytherapy is necessary and feasible. Int J Radiat Oncol Biol Phys 2010; 76: 1066-72. 
